(-) ISAHP 2020 


\section{COPYRIGHT ISAHP 2020 PROCEEDINGS}

\section{Library of Congress Publication Data}

Proceedings of the International Symposium on the Analytic Hierarchy Process: the $16^{\text {th }}$ ISAHP conference. Publication date: December 2020

\section{Printed Schedule and Abstracts}

ISBN 978-1-888603-61-3

Copyright (C) 2020 by Creative Decision Foundation on behalf of the International Symposium on the Analytic Hierarchy Process

All Rights reserved. The complete proceedings of the ISAHP meeting of 2020 is available online at www.isahp.org.

Online Proceedings: ISSN 1556-8296

No part of this publication may be reproduced, stored in retrieval system, or transmitted, in any form or by any means, electronic, mechanical, photocopying, recording, or otherwise, without the prior written permission of the publisher.

\section{CONTACTS}

\section{Rozann Whitaker Saaty}

Creative Decisions Foundation

4922 Ellsworth Avenue

Pittsburgh, PA 15213

Phone: 412-621-6546

E-mail: rozann@creativedecisions.net 
THOMAS SAATY IN MEMORIAM .....................................................8

MESSAGE FROM THE PRESIDENT OF CREATIVE DECISIONS

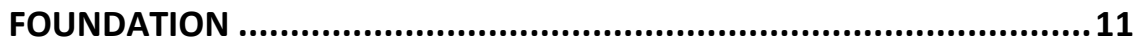

MESSAGE FROM THE PROGRAM COMMITTEE..................................12

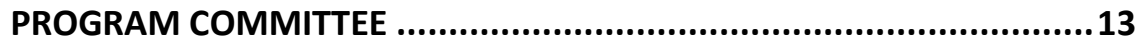

ISAHP2020 International Scientific Advisory Committee.................... 14

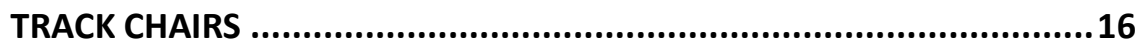

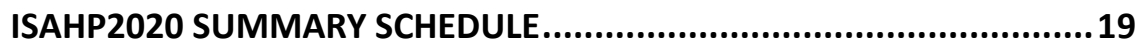

BREAK OUT SESSIONS SUMMARY SCHEDULE ................................23

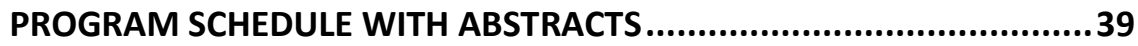

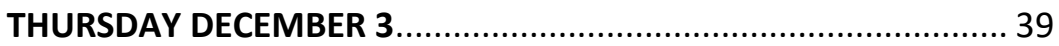

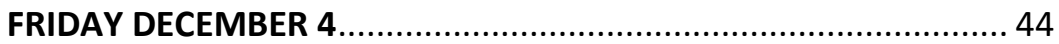

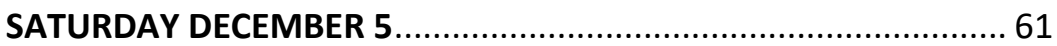

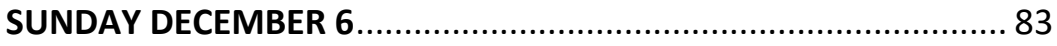

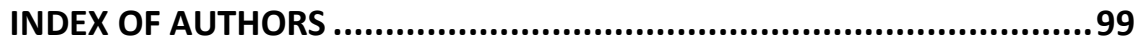

CONFERENCE PARTICIPANTS - CONTACT INFORMATION.................. 103 


\section{Thomas Saaty (1926 -2017)}

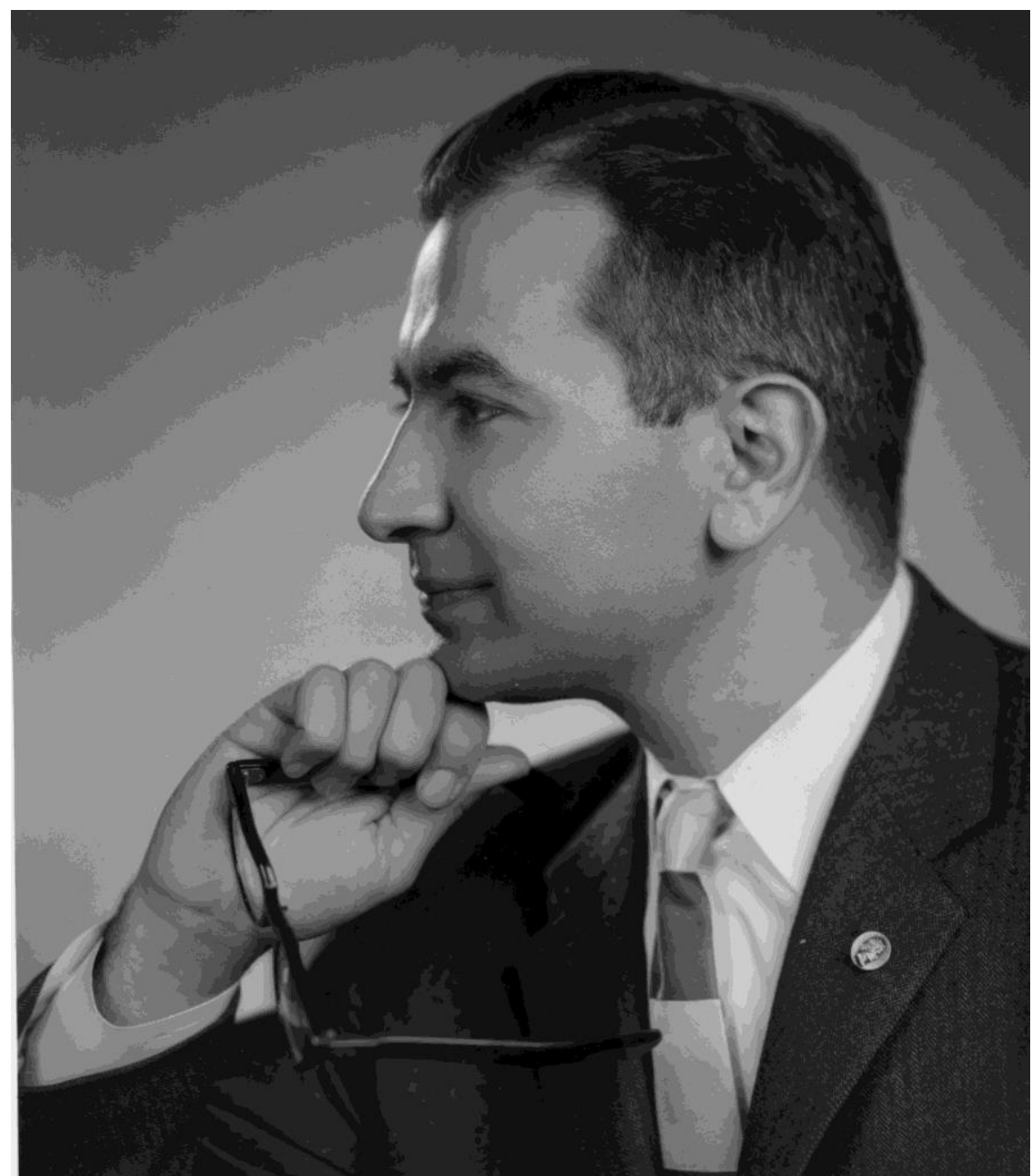

Thomas Saaty in 1959 - Age 33 in London while working at the US Embassy for the Office of Naval Research 
Tom Saaty was born in Mosul, Iraq, on July 18, 1926. His parents were descendants from Assyrian Christians from northern Iraq. His father, David Saaty, lived in Rhode Island for many years, but returned to his home town of Mosul in the early 1900s. David was a well-known entrepreneur whose ambition was to modernize Iraq; he opened the country's first ice-making factory in 1923. David married Tom's mother, Dola, in 1925. Tom was their first child. They had three other childrenJohn, Ben, and Grace.

Tom went to Brummana High School in Lebanon, a Quaker school, when he was 15, and after graduation attended the American University of Beirut for two years. When he was 19 he went to the U.S. to attend Columbia Union College in Takoma Park, Maryland. He then attended the Catholic University of America, receiving a M.S. degree in Physics. He received a Ph.D. in Mathematics from Yale University in 1953 under Professor Einer Hille, and he did postgraduate work for a year at La Sorbonne, Paris, under the direction of Henri Cartan.

After graduating from Yale, and, despite efforts by Einer Hille who wanted Tom to stay at Yale to do research, he joined Melpar, Inc. (1953-54) ) as a scientific analyst studying submarine defense. In 1954, he joined the Operations Evaluation Group (OEG) in Washington D.C. OEG was formed in 1945 from the World War II Operations Research Group that evolved from the Antisubmarine Warfare Operations Research Group organized by Philip Morse in 1942. At OEG, Tom worked on classified submarine detection problems and the mathematics of radar reconnaissance, a topic of 
interest due to U.S. aircraft flights (RB48 and U-2) over the Soviet Union. In 1958, he was appointed scientific liaison officer to the U.S. Embassy in London. In 1959, he was named Director of Advanced Planning in the Office of Naval Research (ONR), a post he held until 1961 when he was appointed as Scientific Analyst in the Arms Control and Disarmament Agency (ACDA), Department of State, where he stayed from 1963 till 1969. In 1969, Tom left ACDA and started his academic career as a professor at the University of Pennsylvania, and in 1979, moved to the University of Pittsburgh where he held a Distinguished University Professor Chair, with appointments to the Philosophy of Science department; the department of Operations, Decision Sciences and Artificial Intelligence at the Joseph M. Katz Graduate School of Business; the School of Engineering; the department of Mathematics; and the department of Sociology.

Tom has made many contributions in a variety of fields from queueing theory to mathematical models of arms control, but he is best known for his Analytic Hierarchy/Network Process theory.

Creativity in just about all fields, especially mathematics, has been a continuing area of Tom's research. His book Creative Thinking, Problem Solving and Decision Making ties together his main pursuits and interests in this area.

Tom was elected a fellow of the American Association for the Advancement of Science (AAAS) in 1959 and, in 1970, to the Real Academia de Ciencias Exactas, Fisicas y Naturales (Royal Academy of Mathematical, Physical and Natural Sciences) of Spain. In 1998, he was elected member of the International Academy of Management. In 2000, he received the Gold Medal of The International Society on Multiple Criteria Decision Making. In 2005, he was elected a member of the National Academy of Engineering. In 2007, he was awarded the International Quality Function Deployment Akao Prize from Japan, and in 2008, he was awarded 
INFORMS Impact Prize for the development of the Analytic Hierarchy Process theory.

Tom loved music and humor. He possessed CDs and records of all of Beethoven's works and, at one point in his life, could identify any Beethoven's piece. In a different vein, when he was younger, it was clear to him he was not good at telling jokes. As a way of his studying how to be a raconteur of jokes, he had, over the years, compiled hundreds of jokes into many booklets under a wide variety of pseudonyms. He shared and recounted this collection with colleagues and friends, and with his classes.

On a personal note. I worked with Tom for over 40 years but I consider him more a father than a coworker, for I knew him longer and spent more time with him than my own father. I met Tom in the Fall of 1975 when I came to study under him from Spain. From the beginning, I was considered part of his family. After 40 years spent with him I cannot find words to express the sadness I feel, but I am happy to think that perhaps now he has found the answers he was looking for to the innumerable questions he had about physics, mathematics, science and life in general.

By Luis Vargas first published in MCDM News, September 2, 2017 


\section{MESSAGE FROM THE PRESIDENT OF CREATIVE DECISIONS FOUNDATION}

It is my pleasure to welcome you to the first virtual conference of the International Symposium of AHP (ISAHP). This ISAHP conference should have been in the summer of 2020. Because of the Corona19 virus, after much delay and many inquiries from the AHP community about what we planned to do, the ISAHP Organizing Committee decided it was time to join the virtual world with ISAHP2020. The ISAHP2020 virtual conference will be the $16^{\text {th }}$ such meeting. I am proud to say these conferences have been international in every sense of the word, held in cities worldwide, and with never less than 30 countries represented by the participants.

The AHP has spread a great deal since my husband Thomas Saaty developed it forty years ago. It is known mostly for its use in decision making, though in truth it is more a way to give human beings a way to measure things in a fast-changing relative universe where everything affects every other thing.

Tom often said he felt he was only the messenger, that his role was to bring AHP and ANP to the world in the hope that it would help everyone make better decisions. Each of you is working to carry on that dream as you apply AHP and ANP in various disciplines, teach it in universities, and help companies and government agencies better allocate their resources. The most important thing any of us do is make good decisions.

Thanks to you, Tom's longtime colleagues and friends, and the members of the AHP community, for joining us once more in this virtual conference.

\section{Rozann Saaty}

President

Creative Decisions Foundation

Pittsburgh, Pennsylvania USA 
Welcome to ISAHP 2020!

It is a pleasure to welcome all members of our AHP/ANP community to our first virtual meeting. Unfortunately, this meeting takes place within the context of the world pandemic that has caused so much pain and sorrow. This is our second meeting still marked by the loss of Dr. Thomas Saaty, who passed away three years ago. Tom, as most of us

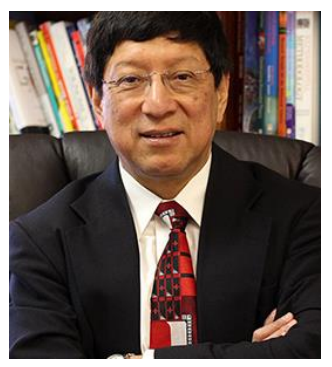
knew him, was the creator of AHP/ANP methodology and founder -along with his wife Rozann- of the Creative Decisions Foundation (CDF). CDF provides funds to organize this symposium and also grants for scholars and students to attend this event. This meeting, whose theme is "AHP/ANP The Next Generation" is not only dedicated to Tom's memory and to his legacy but also to our desire to recruit a new generation of AHP/NP researchers and practitioners interested in promoting better decision making in an ever more complex world. Finally, I would like to express my recognition to all the members of the organizing committee: CDF president Rozann Saaty, program co-chairs Antonella Petrillo and Elena Rokou, the head of the scientific committee Birsen Karpak and our hard-working conference manager Lirong Wei. Without them this even would not have been possible. Enjoy the symposium!

\section{Enrique Mu, PhD}

President

Executive Committee, ISAHP

Antonella Petrillo, PhD

Conference Co-Chair

Elena Rokou, PhD

Conference Co-Chair

Birsen Karpak, PhD

Head of Scientific Committee 


\section{Enrique Mu}

Carlow University - University of Pittsburgh

President of the ISAHP Executive Council

Editor-in-Chief of the International Journal of The Analytic

Hierarchy Process (IJAHP)

Conference Chairman

\section{Antonella Petrillo}

Parthenope University of Naples

Co-Chair

\section{Elena Rokou}

Creative Decisions Foundation

Co-Chair

\section{Birsen Karpak}

Youngstown State University

Head of Scientific Committee

Rozann Saaty

Creative Decisions Foundation

President

Conference sponsor 


\section{ADVISORY COMMITTEE}

\begin{tabular}{|c|c|c|}
\hline $\begin{array}{l}\text { Ririn Astanti } \\
\text { Indonesia }\end{array}$ & $\begin{array}{l}\text { Nkemdinim Dixon- } \\
\text { Ogbechi }\end{array}$ & $\begin{array}{l}\text { University of } \\
\text { Science and }\end{array}$ \\
\hline Majid Azizi & University of Lagos, & Technology \\
\hline Faculty of Natural & Akoka -Yaba & Poland \\
\hline Resources, Karaj & Nigeria & Didit Herawan \\
\hline Iran & Qingxing Dong & Indonesia \\
\hline Pablo Aragonés & Central China & Alessio Ishizaka \\
\hline Beltrán & Normal University & University of \\
\hline University of & China & Portsmouth \\
\hline Valencia & Miroslaw Dytczak & United Kingdom \\
\hline Spain & AGH Academy of & Rafikul Islam \\
\hline Asma Bahurmoz & Science and & International Islamic \\
\hline King Abdul Aziz & Technology, Poland & University \\
\hline University & Emilio Esposito & Malaysia \\
\hline Saudi Arabia & University of Naples & Josef Jablonsky \\
\hline Ozden Bayazit & "Federico II" & University of \\
\hline Central Washington & Italy & Economics \\
\hline University & Peter Fiala & Czech Republic \\
\hline United States & University of & BIrsen Karpak \\
\hline Nina Bejicevic & Economics & Youngstown State \\
\hline University of Zagreb & Czech Republic & University \\
\hline Croatia & Giuseppe Fico & United States \\
\hline Shashi Bhattarai & Universidad & Cengiz Kahraman \\
\hline Knowledge Holding & Politecnica Madrid & Istanbul Technical \\
\hline International & Spain & University \\
\hline Nepal & Anna Florek- & Turkey \\
\hline Mario Castillo & Paszkowska & Eizo Kinoshita \\
\hline Universidad de los & Jagiellonian & Meijo University \\
\hline Andes & University & Japan \\
\hline Colombia & Poland & Konstantinos \\
\hline Orrin Cooper & Mónica & Kirytopoulos \\
\hline University of & García Melón & University of \\
\hline Memphis & Universitat & Aegean \\
\hline United States & Politècnica de & Greece \\
\hline Fabio De Felice & València Spain & Saroj Koul \\
\hline University of & Claudio Garuti & India \\
\hline Cassino and & Fulcrum Ingeniería, & Stan Lipovetsky \\
\hline Southern Lazio & Santiago & GFK Custom \\
\hline Italy & Chile & Research North \\
\hline Bolajoko & Grzegorz Ginda & America \\
\hline
\end{tabular}




\begin{tabular}{|c|c|}
\hline United States & Elena Rokou \\
\hline Oliver Meixner & Creative Decisions \\
\hline University of & Foundation \\
\hline Natural Resources & United States \\
\hline and Applied Life & Valerio Salomon \\
\hline Sciences, Vienna & UNESP-Universidade \\
\hline Austria & Estadual Paulista, \\
\hline Ludmil Mikhailov & Brazil \\
\hline University of & Yuji Sato \\
\hline Manchester & Chukyo University \\
\hline United Kingdom & Japan \\
\hline Karel Mls & Jennifer Shang \\
\hline University of Hradec & University of \\
\hline Kralove & Pittsburgh \\
\hline Czech Republic & United States \\
\hline Enrique Mu & Hsu-Shih Shih \\
\hline Carlow University & Tamkang University \\
\hline United States & Taiwan \\
\hline Gabriella Marcarelli & Patrizia Simeoni \\
\hline University of Sannio & Università degli \\
\hline Italy & Studi di Udine \\
\hline Anna Ostrega & Italy \\
\hline Akademia Gorniczo- & Isabel Spencer \\
\hline Hutni & Fulcrum Ingeniería, \\
\hline Poland & Santiago \\
\hline Mujgan Sagir & Chile \\
\hline Ozdemir & Ilker Topçu \\
\hline Eskisehir Osmangazi & Istanbul Technical \\
\hline University & University \\
\hline Turkey & Turkey \\
\hline Elio Padoano & Luis Vargas \\
\hline University of Trieste & University of \\
\hline Italy & Pittsburgh \\
\hline Leandro Pecchia & United States \\
\hline University of & Xiaojun Wang \\
\hline Warwick & University of Briston \\
\hline United Kingdom & United Kingdom \\
\hline Antonella Petrillo & Min-Suk Yoon \\
\hline University of Naples & Chonnam National \\
\hline Italy & University \\
\hline Rocío Poveda- & Korea \\
\hline Bautista & Keyu Zhu (Andy) \\
\hline Spain & China \\
\hline
\end{tabular}


TRACK \#1: MULTI-CRITERIA DECISION ANALYSIS METHODOLOGY AND THEORY

\section{Luis Vargas}

University of Pittsburgh, USA

lgvargas@pitt.edu

Jose Maria Moreno Jimenez

University of Zaragoza, Spain

Moreno@unizar.es

TRACK \#2 - GOVERNMENT, SOCIAL POLICY AND DECISION MAKING

\section{Ilker Topcu}

Istanbul Technical University, Turkey

topcuil@itu.edu.tr

\section{Cigdem Kadaifci}

Istanbul Technical University, Turkey

cigdem.kadaifci@gmail.com

TRACK \#3 - INDUSTRIAL AND MANUFACTURING

ENGINEERING

\section{Rafikul Islam}

Islamic University of Malaysia, Malaysia rislam@iium.edu.my

\section{Azilah Anis}

Universiti Teknologi MARA, Malaysia

zilahanis@salam.uitm.edu.my

TRACK \#4 - BUSINESS AND INNOVATION

\section{Alessio Ishizaka}

NEOMA Business School, France

alessio.ishizaka@neoma-bs.fr 


\section{Siamak Kheybari}

NEOMA Business School, France

siamak.kheybari@neoma-bs.fr

TRACK \#5 - HEALTHCARE DECISION MAKING

\section{Claudio Garuti}

FULCRUM, Chile

claudiogaruti@fulcrum.cl

Mario Sandoval

BIOMER, Chile

marsam1061@gmail.com

TRACK \#6 - ETHICS, SOCIAL RESPONSIBILITY AND

SUSTAINABILITY

\section{Monica Garcia Melon}

Politecnico de Valencia, Spain

mgarciam@dpi.upv.es

Hannia Gonzalez

Politecnico de Valencia, Spain

gonzalezurango@gmail.com

TRACK \#7 - RISK ANALYSIS AND DISASTER MANAGEMENT

\section{Mujgan Sagir}

Eskisehir Osmangazi University, Turkey

mujgan.sagir@gmail.com

Xi Chen

Xidian University, China

xchen@xidian.edu.cn

TRACK \#8 - SUPPLY CHAIN MANAGEMENT

\section{Valerio Salomon}

Sao Paulo University, Brazil

valerio.salomon@unesp.br

\section{Miguel Angel Ortiz Barrios}

Universidad de la Costa, Colombia

mangelo2008@gmail.com 
TRACK \#9 - INFORMATION TECHNOLOGY

Nina Begicevic

University of Zagreb, Croatia

nina.begicevic@foi.hr

Nikola Kadoic

University of Zagreb, Croatia

nkadoic@foi.hr

TRACK \#10 - ENTREPRENEURSHIP

\section{Anna Florek}

CENTRUM - Lima, Peru

aflorekpaszkowska@pucp.edu.pe

\section{Shashi Bhattarai}

Knowledge Holding Intl, Nepal

shashibhattarai@yahoo.com

TRACK \#11 - APPLICATIONS IN CIVIL ENGINEERING AND URBAN MANAGEMENT

\section{Orrin Cooper}

University of Memphis, USA

olcooper@memphis.edu 


\begin{tabular}{|l|l|l|l|}
\hline \multicolumn{2}{|c|}{ THURSDAY DECEMBER 3 } \\
\hline Time & Room & Title & Presenter \\
\hline 8:05am & $\begin{array}{l}\text { Zoom Workshop } \\
\text { Room 1 }\end{array}$ & $\begin{array}{l}\text { WR1 - Workshop 1: Sensitivity } \\
\text { Analysis }\end{array}$ & $\begin{array}{l}\text { Dr. Orrin Cooper (United } \\
\text { States) - University of Memphis }\end{array}$ \\
\hline 9:05am & $\begin{array}{l}\text { Zoom Workshop } \\
\text { Room 2 }\end{array}$ & $\begin{array}{l}\text { WRK2 - Workshop 2: How to } \\
\text { conduct a negotiation using AHP }\end{array}$ & $\begin{array}{l}\text { Prof. Luis Vargas (United States) } \\
\text { - University of Pittsburgh }\end{array}$ \\
\hline 10:05am & $\begin{array}{l}\text { Zoom Workshop } \\
\text { Room 3 }\end{array}$ & $\begin{array}{l}\text { WRK3 - Workshop 3: How to } \\
\text { improve your chance of getting } \\
\text { your AHP/ANP paper published }\end{array}$ & $\begin{array}{l}\text { Dr. Enrique Mu (United States) } \\
\text { - Carlow University }\end{array}$ \\
\hline 11:05am & $\begin{array}{l}\text { Zoom Workshop } \\
\text { Room 4 }\end{array}$ & $\begin{array}{l}\text { WRK4 - Workshop 4: The how and } \\
\text { whys of ANP row sensitivity }\end{array}$ & $\begin{array}{l}\text { Dr. William Adams (United } \\
\text { States) - Decision Lens }\end{array}$ \\
\hline 12:05pm & $\begin{array}{l}\text { Zoom Workshop } \\
\text { Room 5 }\end{array}$ & $\begin{array}{l}\text { WRK5 - Workshop 5: Benefits- } \\
\text { Opportunities-Costs and Risks } \\
\text { calculations demystified }\end{array}$ & $\begin{array}{l}\text { Dr. Elena Rokou - Creative } \\
\text { Decisions Foundation }\end{array}$ \\
\hline 1:05pm & $\begin{array}{l}\text { Zoom Workshop } \\
\text { Room 6 }\end{array}$ & $\begin{array}{l}\text { WRK6 - Workshop 6: Meeting } \\
\text { Facilitation }\end{array}$ & Mr. Daniel Saaty - Decision Lens \\
\hline
\end{tabular}




\begin{tabular}{|c|l|l|l|}
\hline \multirow{2}{*}{ Time } & Room & Title & Presenter \\
\hline 8:05am & Zoom WELC & WELC - Welcome to ISAHP 2020 & $\begin{array}{l}\text { Dr. Enrique Mu (United States) - } \\
\text { Carlow University } \\
\text { Rozann Saaty (United States) - } \\
\text { Creative Decisions Foundation }\end{array}$ \\
\hline \multirow{2}{*}{ 9:05am } & Zoom FR_T1_S1, & $\begin{array}{l}\text { Break Out Sessions: } \\
\text { FR_T1_S1 - Track 1 - Session 1, } \\
\text { FR_T6_S1 - Track 6 - Session 1 }\end{array}$ & \\
\hline 10:05am & Zoom FR_T6_S1 & $\begin{array}{l}\text { KEY1 - Leadership in complex and } \\
\text { chaotic situations }\end{array}$ & $\begin{array}{l}\text { Dr. Blaženka Divjak (Croatia) - } \\
\text { University of Zagreb, Faculty of } \\
\text { organization and informatics }\end{array}$ \\
\hline 11:05am & $\begin{array}{l}\text { Zoom FR_T2_S1, } \\
\text { Zoom FR_T3_S1 }\end{array}$ & $\begin{array}{l}\text { Break Out Sessions: } \\
\text { FR_T2_S1 - Track 2 - Session 1, } \\
\text { FR_T3_S1 - Track 3 - Session 1 }\end{array}$ & \\
\hline 12:05pm & $\begin{array}{l}\text { Zoom FR_T1_S2, } \\
\text { Zoom FR_T5_S1 }\end{array}$ & $\begin{array}{l}\text { FR_T1_S2 - Track 1 - Session 2, } \\
\text { FR_T5_S1 - Track 5 - Session 1 }\end{array}$ & \\
\hline 1:05pm & Zoom POS1 & POS1 - Poster Session 1 & \\
\hline
\end{tabular}




\begin{tabular}{|c|c|c|c|}
\hline \multicolumn{4}{|c|}{ SATURDAY DECEMBER 5} \\
\hline Time & Room & Title & Presenter \\
\hline 8:05am & $\begin{array}{l}\text { Zoom SA_T2_S2, } \\
\text { Zoom SA_T6_S2 }\end{array}$ & $\begin{array}{l}\text { Break Out Sessions: } \\
\text { SA_T2_S2 - Track } 2 \text { - Session 2, } \\
\text { SA_T6_S2 - Track } 6 \text { - Session } 2\end{array}$ & \\
\hline 9:05am & $\begin{array}{l}\text { Zoom SA_T1_S3 } \\
\text { Zoom SA_T7_S1 }\end{array}$ & $\begin{array}{l}\text { Break Out Sessions: } \\
\text { SA_T1_S3 - Track } 1 \text { - Session 3, } \\
\text { SA_T7_S1 - Track } 7 \text { - Session 1 }\end{array}$ & \\
\hline 10:05am & Zoom PLN1 & $\begin{array}{l}\text { PLN1 - Plenary: Three } \\
\text { developments of the Analytic } \\
\text { Hierarchy Process: } \\
\text { Calibrated Fuzzy AHP, AHPSort and } \\
\text { GAHPO }\end{array}$ & $\begin{array}{l}\text { Prof. Alessio Ishizaka (France) - } \\
\text { NEOMA Business School }\end{array}$ \\
\hline 11:05am & $\begin{array}{l}\text { Zoom SA_T2_S3, } \\
\text { Zoom SA_T8_S1 }\end{array}$ & $\begin{array}{l}\text { Break Out Sessions: } \\
\text { SA_T2_S3 - Track } 2 \text { - Session 3, } \\
\text { SA_T8_S1 - Track } 8 \text { - Session 1 }\end{array}$ & \\
\hline $12: 05 p m$ & $\begin{array}{l}\text { Zoom SA_T1_S4, } \\
\text { Zoom SA_T11_S1 }\end{array}$ & $\begin{array}{l}\text { Break Out Sessions: } \\
\text { SA_T1_S4 - Track } 1 \text { - Session 4, } \\
\text { SA_T11_S1 - Track } 11 \text { - Session } 1\end{array}$ & \\
\hline $1: 05 p m$ & Zoom POS2 & POS2 - Poster Session 2 & \\
\hline
\end{tabular}




\section{SUNDAY DECEMBER 6}

\begin{tabular}{|c|c|c|c|}
\hline Time & Room & Title & Presenter \\
\hline 8:05am & $\begin{array}{l}\text { Zoom SU_T2_S4, } \\
\text { Zoom SU_T6_T7 }\end{array}$ & $\begin{array}{l}\text { Break Out Sessions: } \\
\text { SU_T2_S4 - Track } 2 \text { - Session 4, } \\
\text { SU_T6_T7 - Tracks } 6 \text { and } 7\end{array}$ & \\
\hline 9:05am & $\begin{array}{l}\text { Zoom SU_T1_S5, } \\
\text { Zoom SU_T5_S2 }\end{array}$ & $\begin{array}{l}\text { Break Out Sessions: } \\
\text { SU_T1_S5 - Track } 1 \text { - Session 5, } \\
\text { SU_T5_S2 - Track } 5 \text { - Session } 2\end{array}$ & \\
\hline 10:05am & Zoom PLN2 & $\begin{array}{l}\text { PLN2 - Plenary: AHP/ANP: Issues } \\
\text { and Insights for the Future }\end{array}$ & $\begin{array}{l}\text { Dr. William Wedley (Canada) - Simon Fraser } \\
\text { University }\end{array}$ \\
\hline 11:05am & $\begin{array}{l}\text { Zoom SU_T3_S2, } \\
\text { Zoom SUN_APPS }\end{array}$ & $\begin{array}{l}\text { Break Out Sessions: } \\
\text { SU_T3_S2 - Track } 3 \text { - Session 2, } \\
\text { SUN_APPS - AHP Applications }\end{array}$ & \\
\hline $12: 05 p m$ & Zoom SU_T4_S1 & $\begin{array}{l}\text { Break Out Sessions: } \\
\text { SU_T4_S1 - Track } 4 \text { - Session } 1\end{array}$ & \\
\hline $1: 05 p m$ & Zoom PNL1 & PNL1 - AHP Students Roundtable & $\begin{array}{l}\text { Dr. Enrique Mu (United States) - Carlow University } \\
\text { Dr. Elena Rokou - Creative Decisions Foundation } \\
\text { Dr. Anna Florek-Paszkowska (Peru) - CENTRUM } \\
\text { Católica Graduate Business School, Lima, Perú } \\
\text { Pontificia Universidad Católica del Perú, Lima, Perú }\end{array}$ \\
\hline 2:05pm & Zoom AWRD & $\begin{array}{l}\text { AWRD - Closing/ Awards } \\
\text { Ceremony }\end{array}$ & $\begin{array}{l}\text { Dr. Enrique Mu (United States) - Carlow University } \\
\text { Rozann Saaty (United States) - Creative Decisions } \\
\text { Foundation }\end{array}$ \\
\hline
\end{tabular}




\begin{tabular}{|c|c|c|}
\hline \multicolumn{3}{|c|}{ FRIDAY DECEMBER 4 - BREAK OUT SESSIONS } \\
\hline \multicolumn{3}{|l|}{ FRIDAY 9:05 am } \\
\hline Zoom FR_T1_S1 & $\begin{array}{l}\text { Track } 1 \text { - Session } 1 \\
\text { Prof. Luis Vargas (United State }\end{array}$ & University of Pittsburgh \\
\hline \multicolumn{2}{|c|}{$\begin{array}{l}\text { TRANSFORMING AHP GROUP DECISIONS INTO FUZZY } \\
\text { PRIORITIES - A NEW METHODOLOGY TO AGGREGATE } \\
\text { INDIVIDUAL PRIORITIES }\end{array}$} & $\begin{array}{l}\text { Oliver Meixner (Austria) }{ }^{1} \text {, Sonja Hackl (Austria) }{ }^{1}, \text { Rainer Haas (Austria) }{ }^{1} \\
\text { (1. University of Natural Resources and Life Sciences Vienna) }\end{array}$ \\
\hline \multicolumn{2}{|c|}{$\begin{array}{l}\text { AN UPDATE ON COMBINATORIAL METHOD FOR } \\
\text { AGGREGATION OF EXPERT JUDGMENTS IN AHP }\end{array}$} & $\begin{array}{l}\text { Sergii Kadenko (Ukraine) }{ }^{1} \text {, Vitaliy Tsyganok (Ukraine) }{ }^{1} \text { (1. Institute for } \\
\text { Information Recording of the National Academy of Scienes of Ukraine) }\end{array}$ \\
\hline \multicolumn{2}{|c|}{$\begin{array}{l}\text { VECTOR COMPRESSION METHOD TO CONVERT THE } \\
\text { INCOMPLETE MATRIX OF PAIRWISE COMPARISONS IN } \\
\text { THE ANALYTIC HIERARCHY PROCESS }\end{array}$} & $\begin{array}{l}\text { Alexander Bochkov (Russian Federation) }{ }^{1} \text {, Alexandra Ridley (Russian } \\
\text { Federation) }{ }^{2} \text {, Nataliya Kuzmina (Russian Federation) }{ }^{3} \text {, Nikolay Zhigirev } \\
\text { (Russian Federation) }^{4} \text { (1. JSC NIIAS, 2. Moscow Aviation Institute } \\
\text { (National Research University), 3. Moscow State Technical University } \\
\text { of Civil Aviation, 4. KALABI IT) }\end{array}$ \\
\hline Zoom FR_T6_S1 & $\begin{array}{l}\text { Track } 6 \text { - Session } 1 \\
\text { Dr. Monica Garcia Melor }\end{array}$ & ain) - Ingenio (CSIC-UPV) \\
\hline
\end{tabular}




\begin{tabular}{|c|c|c|}
\hline \multicolumn{2}{|c|}{$\begin{array}{l}\text { BUSINESSES AS SOCIAL PARTNERS IN GENDER POLICIES: } \\
\text { ASSESSMENT OF THE ACTORS' EXPECTATIONS TO } \\
\text { CONTRIBUTE TO GENDER EQUALITY }\end{array}$} & $\begin{array}{l}\left.\text { Paula Otero-Hermida (Spain) }{ }^{1} \text {, Hannia Gonzalez-Urango (Spain) }\right)^{2}(1 . \\
\text { Ingenio (CSIC-UPV), 2. Ingenio (CSIC-UPV), Universitat Politècnica de } \\
\text { València) }\end{array}$ \\
\hline \multicolumn{2}{|c|}{$\begin{array}{l}\text { A TOOL FOR MONITORING THE UNDER } \\
\text { REPRESENTATION OF WOMEN IN CONFERENCES AND } \\
\text { EVENTS }\end{array}$} & $\begin{array}{l}\text { Carmen Corona-Sobrino (Spain) }{ }^{1} \text {, (Spain) }{ }^{2} \text {, Rocío Poveda-Bautista } \\
(\text { Spain })^{2} \text {, Hannia Gonzalez-Urango (Spain) }{ }^{2} \text { (1. Ingenio (CSIC-UPV), } \\
\text { Universitat Politècnica de València; Departamento Sociologia I } \\
\text { Universidad de Alicante, 2. Ingenio (CSIC-UPV), Universitat Politècnica } \\
\text { de València) }\end{array}$ \\
\hline \multicolumn{2}{|c|}{$\begin{array}{l}\text { ANPSORT II METHOD: AN EXPERIMENTATION TO ASSESS } \\
\text { THE RESILIENCE OF A SOCIO-ECOLOGICAL SYSTEM }\end{array}$} & $\begin{array}{l}\text { Vanessa Assumma (Italy) })^{1} \text {, Marta Bottero (Italy) }{ }^{1} \text {, Alessio Ishizaka } \\
\text { (France) })^{3} \text { (1. Polytechnic University of Turin, } 2 . \text { NEOMA Business } \\
\text { School) }\end{array}$ \\
\hline \multicolumn{3}{|l|}{ FRIDAY 11:05am } \\
\hline Zoom FR_T2_S1 & \multicolumn{2}{|c|}{$\begin{array}{l}\text { Track } 2 \text { - Session } 1 \\
\text { Ilker Topcu (Turkey) - istanbul technical university }\end{array}$} \\
\hline \multicolumn{2}{|c|}{$\begin{array}{l}\text { A MULTI-ATTRIBUTE DECISION MAKING MODEL FOR } \\
\text { HOSPITAL LOCATION SELECTION }\end{array}$} & $\begin{array}{l}\text { Gül İmamoğlu (Turkey) }{ }^{1} \text {, Ilker Topcu (Turkey) }{ }^{2} \text { (1. Karadeniz Technical } \\
\text { University, 2. istanbul technical university) }\end{array}$ \\
\hline \multicolumn{2}{|c|}{$\begin{array}{l}\text { UNCERTAINTY AND COMPATIBILITY IN AHP MODELING: } \\
\text { CONSENSUS BUILDING IN PROJECT PORTFOLIO } \\
\text { FORMULATION FOR MULTILATERAL ORGANIZATIONS }\end{array}$} & $\begin{array}{l}\text { lleana Grave (Mexico) }{ }^{1} \text {, Paola Gómez-Priego (Mexico) }{ }^{1} \text {, Luis Antonio } \\
\text { Bojórquez-Tapia (Mexico) }{ }^{3} \text { (1. Laboratorio Nacional de Ciencias de la } \\
\text { Sostenibilidad, 2. Laboratorio Nacional de Ciencias de la } \\
\text { Sostenibilidad, Instituto de Ecología, UNAM) }\end{array}$ \\
\hline
\end{tabular}




\begin{tabular}{|c|c|c|}
\hline \multicolumn{2}{|c|}{$\begin{array}{l}\text { NEUTROSOPHIC ANALYTIC HIERARCHY PROCESS FOR } \\
\text { EVALUATING A NEW SERVICIZING BUSINESS MODEL OF } \\
\text { TRANSPORTATION }\end{array}$} & Saliha Karadayi-Usta (Turkey) ${ }^{1}$ (1. Fenerbahce University) \\
\hline Zoom FR_T3_S1 & $\begin{array}{l}\text { Track } 3 \text { - Session } 1 \\
\text { Prof. Rafikul Islam (Malaysia) - De } \\
\text { Malaysia }\end{array}$ & partment of Business Administration, International Islamic University \\
\hline \multicolumn{2}{|c|}{$\begin{array}{l}\text { LAYOUT ASSESSMENT WITH STRUCTURING AND } \\
\text { MATHEMATICAL MODELING BY THE AHP METHOD }\end{array}$} & $\begin{array}{l}\text { Lucas Ramon dos Hermogenes (Brazil) }{ }^{1} \text {, Miguel Moreira (Brazil) }{ }^{1} \text {, } \\
\text { Lorena Berzins (Brazil) }{ }^{3} \text {, Marcos dos Santos }\left(\text { Brazil) }{ }^{1}(1 . \text { Instituto }\right. \\
\text { Militar de Engenharia (IME), 2. Fundação Getúlio Vargas (FGV)) }\end{array}$ \\
\hline \multicolumn{2}{|c|}{$\begin{array}{l}\text { APPLYING AHP TECHNIQUE TO CHOOSE PRODUCT TYPE } \\
\text { IN PAPER FACTORIES }\end{array}$} & 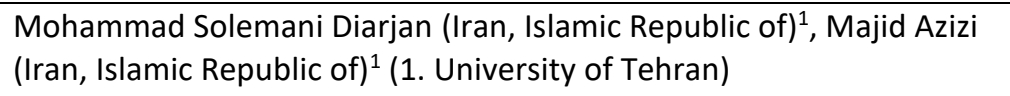 \\
\hline \multicolumn{2}{|c|}{$\begin{array}{l}\text { ENHANCING FINANCIAL AND STRATEGIC PERFORMANCE } \\
\text { OF AN OIL AND GAS COMPANY }\end{array}$} & $\begin{array}{l}\text { Rafikul Islam (Malaysia) }{ }^{1} \text {, Deven Sharma KRISHNAN (Malaysia) }{ }^{2} \text { (1. } \\
\text { Department of Business Administration, International Islamic } \\
\text { University Malaysia, 2. Graduate School of Management, International } \\
\text { Islamic University Malaysia) }\end{array}$ \\
\hline \multicolumn{3}{|l|}{ FRIDAY 12:05 pm } \\
\hline Zoom FR_T1_S2 & $\begin{array}{l}\text { Track } 1 \text { - Session } 2 \\
\text { José María Moreno-Jiménez (Spa }\end{array}$ & \\
\hline \multicolumn{2}{|c|}{$\begin{array}{l}\text { NOTES ON THE USE OF COMPATIBILITY INDEX IN THE } \\
\text { ANALYTIC HIERARCHY PROCESS }\end{array}$} & $\begin{array}{l}\text { MinSuk YOON (Korea, Republic of) }{ }^{1} \text { (1. Electronic Commerce, } \\
\text { Chonnam National University) }\end{array}$ \\
\hline
\end{tabular}




\begin{tabular}{|c|c|c|}
\hline \multicolumn{2}{|c|}{$\begin{array}{l}\text { REDUCING THE NUMBER OF EXPERT PAIR-WISE } \\
\text { COMPARISONS DURING DECISION SUPPORT USING AHP }\end{array}$} & $\begin{array}{l}\text { Oleh Andriichuk (Ukraine) }{ }^{1} \text {, Vitaliy Tsyganok (Ukraine) }{ }^{1} \text {, Sergii Kadenko } \\
\text { (Ukraine) }^{3} \text { (1. National Technical University of Ukraine “Igor Sikorsky } \\
\text { Kyiv Polytechnic Institute", Institute for Information Recording of } \\
\text { National Academy of Sciences of Ukraine, } 2 \text {. Institute for Information } \\
\text { Recording of National Academy of Scienes of Ukraine) }\end{array}$ \\
\hline \multicolumn{2}{|c|}{$\begin{array}{l}\text { PRIORITY VECTOR ESTIMATION: CONSISTENCY, } \\
\text { COMPATIBILITY, PRECISION }\end{array}$} & Stan Lipovetsky (United States) ${ }^{1}$ (1. independent consultant) \\
\hline Zoom FR_T5_S1 & \multicolumn{2}{|c|}{$\begin{array}{l}\text { Track } 5 \text { - Session } 1 \\
\text { Prof. Claudio Garuti (Chile) - Fulcrum Engeneering }\end{array}$} \\
\hline \multicolumn{2}{|c|}{$\begin{array}{l}\text { HOW TO ASSIST TO BETTER AND FASTER MEDICAL } \\
\text { DIAGNOSES THROUGH MEDICAL SAPIENS WEB } \\
\text { PLATFORM }\end{array}$} & Claudio Garuti (Chile) ${ }^{1}$ (1. Fulcrum Engineering) \\
\hline \multicolumn{2}{|c|}{$\begin{array}{l}\text { A DECISION SUPPORT TOOL FOR HOSPITAL PROJECT } \\
\text { SUSTAINABILITY EVALUATION }\end{array}$} & $\begin{array}{l}\left.\text { Carlotta Patrone (Italy) })^{1} \text {, Antonio G. Latora (Italy) }\right)^{2} \text {, Roberto Revetria } \\
(\text { Italy })^{3} \text { (1. E.O. Ospedali Galliera, 2. Regione Lazio, 3. Università degli } \\
\text { Studi di Genova) }\end{array}$ \\
\hline \multicolumn{2}{|c|}{$\begin{array}{l}\text { PRIORITIZING HIGH-RISK DISEASES AND NON-TRAUMA- } \\
\text { MEDIATED DISEASES IN A TRIAGE ON MEDICAL SAPIENS } \\
\text { PLATFORM }\end{array}$} & Kazi Tasnim (United Kingdom) ${ }^{1}$ (1. Student) \\
\hline \multicolumn{3}{|c|}{ FRIDAY 1:05 pm } \\
\hline Zoom POS1 & \multicolumn{2}{|c|}{$\begin{array}{l}\text { Poster Session } 1 \\
\text { Dr. Enrique Mu (United States) - Carlow University }\end{array}$} \\
\hline
\end{tabular}




\begin{tabular}{|c|c|}
\hline BIBLIOMETRIC STUDY ON AHP AND URBAN MOBILITY & 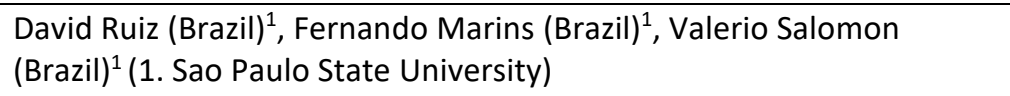 \\
\hline $\begin{array}{l}\text { ADJUSTED INTANGIBILITY-AWARE ASSESSMENT OF THE } \\
\text { UTILISATION OF BIOGAS PLANT TECHNOLOGY } \\
\text { APPLICATION POTENTIAL }\end{array}$ & $\begin{array}{l}\text { Grzegorz Ginda (Poland) }{ }^{1} \text {, Marta Szyba (Poland) }{ }^{1} \text { (1. AGH UST,Cracow, } \\
\text { Poland) }\end{array}$ \\
\hline $\begin{array}{l}\text { HOSPITAL AIRCRAFT IN THE FIGHT AGAINST THE } \\
\text { CORONAVIRUS PANDEMIC: STRUCTURING AND } \\
\text { MODELING A COMPLEX PROBLEM USING AHP AND VFT } \\
\text { METHODS }\end{array}$ & $\begin{array}{l}\text { Igor Pinheiro de Araújo Costa (Brazil) }{ }^{1} \text {, Arthur Pinheiro de Araújo Costa } \\
\text { (Brazil) }^{2} \text {, José Victor de Pina Corriça (Brazil) }{ }^{2} \text {, SÉRGIO MITIHIRO DO } \\
\text { NASCIMENTO MAÊDA (Brazil) }{ }^{1} \text {, Luiz Frederico Horácio de Souza de } \\
\text { Barros Teixeira (Brazil) }{ }^{5} \text {, Marcos Alexandre Pinto de Castro Junior } \\
\text { (Brazil) }^{6} \text {, Carlos Francisco Simões Gomes (Brazil) }{ }^{1}, \text { Marcos dos Santos } \\
\text { (Brazil) }^{8} \text { (1. Universidade Federal Fluminense (UFF), 2. Marinha do } \\
\text { Brasil, 3. Centro de Análises de Sistemas Navais (CASNAV), 4. Pontifícia } \\
\text { Universidade Católica (PUC), 5. Instituto Militar de Engenharia (IME)) }\end{array}$ \\
\hline $\begin{array}{l}\text { APPLICATIONS OF THE ANALYTIC HIERARCHY PROCESS } \\
\text { METHOD IN FORECASTING: A REVIEW OF THE } \\
\text { LITERATURE }\end{array}$ & $\begin{array}{l}\text { Lidiane Cristina Oliveira (Brazil) }{ }^{1}, \text { Bruna Cristine Scarduelli Pachecco } \\
\text { (Brazil) }^{1}, \text { Claudio Luis Piratelli (Brazil) }{ }^{1} \text { (1. University of Araraquara - } \\
\text { UNIARA) }\end{array}$ \\
\hline
\end{tabular}




\section{SATURDAY DECEMBER 5 - BREAK OUT SESSIONS}

\section{SATURDAY 8:05am}

\section{Zoom SA_T2_S2 $\quad$ Track 2 - Session 2 \\ Cigdem Kadaifci}

APPLICATION EXPERIENCE OF THE AHP FOR THE ANTARCTIC ISSUES

AN MCDM APPROACH FOR CROP PATTERN SELECTION

ANALYTIC HIERARCHY PROCESS FOR EVIDENCEBASED POLICY MAKING

Zoom SA_T6_S2 $\quad$ Track 6 - Session 2

Dr. Hannia Gonzalez-Urango (Spain) - Ingenio (CSIC-UPV), Universitat Politècnica de València

SENSITIVITY ANALYSIS FOR THE ASSESSMENT OF ADAPTIVE CAPACITY TO CLIMATE CHANGE: A CASE

OF STUDY FROM BRAZIL

Oleksandr Kuzko (Ukraine) ${ }^{1}$, Mykola Leonov (Ukraine) ${ }^{2}$ (1. Selfemployed, 2. State Institution National Antarctic Scientific Center of Ukraine)

Püren Veziroğlu (Turkey) ${ }^{1}$, Ilker Topcu (Turkey) ${ }^{2}$ (1. cukurova university, 2. istanbul technical university)

Yoichi lida (Japan) ${ }^{1}$ (1. Suwa University of Science)

Ileana Grave (Mexico) ${ }^{1}$, Luis Antonio Bojórquez-Tapia (Mexico) ${ }^{1}$, Alejandra Estrada-Barón (Mexico) ${ }^{1}$, Donald R Nelson (United States) ${ }^{4}$, Hallie Eakin (United States) ${ }^{5}$ (1. Laboratorio Nacional de Ciencias de la Sostenibilidad, Instituto de Ecología, UNAM, 2. University of Georgia, UGA, Department of Anthropology, 3. Arizona State University, School of Sustainability) 


\begin{tabular}{|c|c|c|}
\hline \multicolumn{2}{|c|}{$\begin{array}{l}\text { ASSESSING THE BARRIERS TO THE DEVELOPMENT } \\
\text { OF ELECTRIC VEHICLES IN THE URBAN TRANSPORT } \\
\text { NETWORK OF VALENCIA }\end{array}$} & $\begin{array}{l}\left.\text { Paula Bastida-Molina (Spain) }{ }^{1} \text {, David Ribo-Perez (Spain) }\right)^{1}, \text { Tomás } \\
\text { Gómez-Navarro (Spain) }{ }^{1} \text {, Elías Hurtado-Pérez (Spain) }{ }^{1}(1 . \text { Institute } \\
\text { for Energy Engineering. Universitat Politècnica de València) }\end{array}$ \\
\hline \multicolumn{2}{|c|}{$\begin{array}{l}\text { PRIORITIZING THE EFFECT OF MEDIA'S INFLUENCE } \\
\text { ON PEOPLE'S MENTAL HEALTH PERCEPTIONS }\end{array}$} & $\begin{array}{l}\text { Anastasia Marsh (United States) }{ }^{1} \text {, Enrique Mu (United States) }{ }^{1} \text { (1. } \\
\text { Carlow University) }\end{array}$ \\
\hline \multicolumn{3}{|l|}{ SATURDAY 9:05am } \\
\hline Zoom SA_T1_S3 & \multicolumn{2}{|c|}{$\begin{array}{l}\text { Track } 1 \text { - Session } 3 \\
\text { Prof. Luis Vargas (United States) - University of Pittsburgh }\end{array}$} \\
\hline \multicolumn{2}{|c|}{$\begin{array}{l}\text { ON THE SIMILARITY AMONG PRIORITY DERIVING } \\
\text { METHODS FOR THE AHP }\end{array}$} & Pawel Kazibudzki (Poland) ${ }^{1}$ (1. Opole University of Technology) \\
\hline \multicolumn{2}{|c|}{$\begin{array}{l}\text { PROPOSALS FOR THE SET OF PAIRWISE } \\
\text { COMPARISONS }\end{array}$} & $\begin{array}{l}\text { Zsombor Szádoczki (Hungary) }{ }^{1} \text {, Sándor Bozóki (Hungary) }{ }^{1} \text {, } \\
\text { Hailemariam Abebe Tekile (Italy) }{ }^{3} \text { (1. Corvinus University of } \\
\text { Budapest, 2. University of Trento) }\end{array}$ \\
\hline \multicolumn{2}{|c|}{ ANP SUPERMATRICES: LESSONS FROM HIERARCHIES } & $\begin{array}{l}\text { Orrin Cooper (United States) }{ }^{1} \text {, William Wedley (Canada) }{ }^{2}(1 . \\
\text { University of Memphis, 2. Simon Fraser University) }\end{array}$ \\
\hline
\end{tabular}




\begin{tabular}{|c|c|c|}
\hline Zoom SA_T7_S1 & \multicolumn{2}{|c|}{$\begin{array}{l}\text { Track } 7 \text { - Session } 1 \\
\text { Prof. Xi Chen (China) - Xidian University }\end{array}$} \\
\hline \multicolumn{2}{|c|}{$\begin{array}{l}\text { SELECTION OF APPROPRIATE PROJECT } \\
\text { MANAGEMENT METHODOLOGIES FOR EMERGENCY } \\
\text { PROJECTS USING ANALYTIC HIERARCHY PROCESS }\end{array}$} & $\begin{array}{l}\text { Chris Amponsah (Canada) }{ }^{1} \text {, Tamara Opokua Amponsah (United } \\
\text { States) }{ }^{2} \text { (1. Yorkville University, } 2 \text {. Ross University School of } \\
\text { Medicine) }\end{array}$ \\
\hline \multicolumn{2}{|c|}{$\begin{array}{l}\text { HOW YOUNG POPULATION MAKES PERSONAL } \\
\text { FINANCE DECISIONS? EVIDENCE FROM NORTH } \\
\text { MACEDONIA }\end{array}$} & $\begin{array}{l}\text { Tamara Kaftandzieva (North Macedonia) }{ }^{1} \text {, Violeta Cvetkoska } \\
\text { (North Macedonia) }^{2} \text { (1. PhD Student, 2. Associate Professor) }\end{array}$ \\
\hline \multicolumn{2}{|c|}{$\begin{array}{l}\text { PRIORITIZED MULTI-COMMODITY FLOW MODEL } \\
\text { AND ALGORITHM }\end{array}$} & $\begin{array}{l}\text { Durga Khanal (Nepal) }{ }^{1} \text {, Urmila Pyakurel }(\text { Nepal })^{1}, \text { Tanka Dhamala } \\
(\text { Nepal })^{1}(1 . \text { Tribhuvan University) }\end{array}$ \\
\hline \multicolumn{3}{|c|}{ SATURDAY 11:05am } \\
\hline Zoom SA_T2_S3 & \multicolumn{2}{|l|}{$\begin{array}{l}\text { Track } 2 \text { - Session } 3 \\
\text { Cigdem Kadaifci }\end{array}$} \\
\hline \multicolumn{2}{|c|}{$\begin{array}{l}\text { GUIDANCE FOR HIGHER EDUCATION TO PROVIDE } \\
\text { THE NECESSARY SOFT SKILLS TO MEET THE NEEDS } \\
\text { OF INDUSTRIAL ERA 4.0 USING AHP AND FUZZY AHP }\end{array}$} & $\begin{array}{l}\text { Jozef Raco (Indonesia) })^{1} \text {, James Krejci (United States) }{ }^{2} \text {, Johanis } \\
\text { Ohoitimur (Indonesia) })^{3} \text {, yulius raton (Indonesia) }{ }^{1} \text {, Jeanette } \\
\text { Soputan (Indonesia) })^{5} \text {, Stevanus Ngenget (Indonesia) }{ }^{1} \text {, Frankie } \\
\text { Taroreh (Indonesia) })^{1} \text { (1. Universitas Katolik De La Salle Manado, } 2 . \\
\text { Lewis University, 3. Sekolah Tinggi Filsafat Seminari Pineleng, } 4 . \\
\text { Universitas Sam Ratulangi Manado) }\end{array}$ \\
\hline
\end{tabular}




\begin{tabular}{|c|c|c|}
\hline \multicolumn{2}{|c|}{$\begin{array}{l}\text { INCREASING EXPORT POTENTIAL OF CITRUS } \\
\text { PRODUCTION: A CASE STUDY IN CUKUROVA REGION }\end{array}$} & $\begin{array}{l}\text { Püren Veziroğlu (Turkey) }{ }^{1} \text {, Faruk Emeksiz (Turkey) }{ }^{1} \text { (1. cukurova } \\
\text { university) }\end{array}$ \\
\hline \multicolumn{2}{|c|}{$\begin{array}{l}\text { PROJECT MANAGER SELECTION BY ANALYTIC } \\
\text { HIERARCHY PROCESS }\end{array}$} & $\begin{array}{l}\text { serhat aydin (Turkey) }{ }^{1} \text {, mehmet yorukoglu (Turkey) }{ }^{1} \text { (1. National } \\
\text { Defence University Air Force Academy) }\end{array}$ \\
\hline Zoom SA_T8_S1 & \multicolumn{2}{|c|}{$\begin{array}{l}\text { Track } 8 \text { - Session } 1 \\
\text { Dr. Valerio Salomon (Brazil) - Sao Paulo State University }\end{array}$} \\
\hline \multicolumn{2}{|c|}{$\begin{array}{l}\text { ASSESSING STAKEHOLDERS' CONFLICTS IN URBAN } \\
\text { LOGISTICS NETWORKS THROUGH ANALYTIC } \\
\text { HIERARCHY PROCESS }\end{array}$} & $\begin{array}{l}\text { Francesco Ciardiello (United Kingdom })^{1}, \text { Andrea Genovese } \\
\left.(\text { United Kingdom })^{1}, \text { Shucheng Luo (United Kingdom }\right)^{1}, \text { Antonino } \\
\text { Sgalambro (United Kingdom })^{1} \text { (1. Sheffield University } \\
\text { Management School) }\end{array}$ \\
\hline \multicolumn{2}{|c|}{$\begin{array}{l}\text { MULTI-CRITERIA VALUE ASSESSMENT FOR } \\
\text { BUSINESS-TO-BUSINESS }\end{array}$} & $\begin{array}{l}\left.\text { Ana Beatriz Tocalinho (Brazil) })^{1} \text {, Antonio Netto (Brazil) }\right)^{2} \text {, Valerio } \\
\text { Salomon }\left(\text { Brazil) }{ }^{2} \text { (1. Sao Paulo State University (UNESP), 2. Sao }\right. \\
\text { Paulo State University) }\end{array}$ \\
\hline \multicolumn{2}{|c|}{$\begin{array}{l}\text { STRATEGIC SUPPLIER SELECTION: THE CASE OF } \\
\text { INTERNATIONAL FOOD TRADING COMPANY }\end{array}$} & $\begin{array}{l}\text { Chuvej Chansa-ngavej (Thailand) }{ }^{1}, \text { Natchanok Paramaporn } \\
\text { (Thailand) }^{1}(1 . \text { Regional Center for Manufacturing Systems } \\
\text { Engineering, Chulalongkorn University) }\end{array}$ \\
\hline \multicolumn{3}{|c|}{ SATURDAY 12:05am } \\
\hline Zoom SA_T1_S4 & \multicolumn{2}{|c|}{$\begin{array}{l}\text { Track } 1 \text { - Session } 4 \\
\text { José María Moreno-Jiménez (Spain) }\end{array}$} \\
\hline
\end{tabular}




\begin{tabular}{|c|c|c|}
\hline \multicolumn{2}{|c|}{$\begin{array}{l}\text { AHP AND TWO-ENVELOPE PARADOX RESOLUTION } \\
\text { VIA NONLINEAR SCALING }\end{array}$} & Stan Lipovetsky (United States) ${ }^{1}$ (1. independent consultant) \\
\hline \multicolumn{2}{|c|}{$\begin{array}{l}\text { INFLUENCE ANALYSIS IN ANP MODELS - } \\
\text { ADVANTAGES AND PITFALLS }\end{array}$} & $\begin{array}{l}\text { Elena Rokou (United States) }{ }^{1}, \text { William Adams (United States) }{ }^{2} \text { (1. } \\
\text { CDF, 2. Decision Lens) }\end{array}$ \\
\hline \multicolumn{2}{|c|}{$\begin{array}{l}\text { BUILDING AN EVALUATION "COMMON GROUND" } \\
\text { FOR RESEARCH ON AHP REFINEMENTS }\end{array}$} & robin rivest (Canada) $)^{1}(1$. HEC Montreal) \\
\hline Zoom SA_T11_S1 & \multicolumn{2}{|c|}{$\begin{array}{l}\text { Track } 11 \text { - Session } 1 \\
\text { Dr. Orrin Cooper (United States) - University of Memphis }\end{array}$} \\
\hline \multicolumn{2}{|c|}{$\begin{array}{l}\text { INVESTIGATION OF CATALYST PROJECTS AND } \\
\text { URBAN DESIGN QUALITIES IN SIX CENTRAL STREETS } \\
\text { OF HAMEDAN }\end{array}$} & $\begin{array}{l}\text { sajjad zolfigol (Iran, Islamic Republic of) }{ }^{1} \text {, mehran Alalhesabi (Iran, } \\
\text { Islamic Republic of })^{2} \text {, seyed majid mofidi shemirani (Iran, Islamic } \\
\text { Republic of })^{3} \text { (1. Ph.D. student in Urbanism, School of } \\
\text { Architecture and Environmental Design, Iran University of Science } \\
\text { and Technology., 2. Associate professor of Urbanism, School of } \\
\text { Architecture and Urban Development, Iran University of Science } \\
\text { and Technology., 3. Assistant Professor in urban design, School of } \\
\text { Architecture and Urban Development, Iran University of Science } \\
\text { and Technology.) }\end{array}$ \\
\hline \multicolumn{2}{|c|}{$\begin{array}{l}\text { CLASSIFICATION RELIABILITY FOR GIS-MCDA: AHP } \\
\text { AND SENSITIVITY ANALYSIS }\end{array}$} & $\begin{array}{l}\text { Ileana Grave (Mexico) })^{1}, \text { Victor Hernández-Díaz (Mexico) }{ }^{1} \text {, Fidel } \\
\left.\text { Serrano-Candela }(\text { Mexico })^{1}, \text { Tatiana Merino (Mexico) }\right)^{4} \text {, Yosune } \\
\text { Miquelajauregui (Mexico) }{ }^{1} \text {, Luis Antonio Bojórquez-Tapia }\end{array}$ \\
\hline
\end{tabular}




\begin{tabular}{|c|c|c|}
\hline & & $\begin{array}{l}\text { (Mexico) })^{1} \text { (1. Laboratorio Nacional de Ciencias de la } \\
\text { Sostenibilidad, Instituto de Ecología, UNAM, 2. Posgrado en } \\
\text { Ciencias de la Sostenibilidad, UNAM) }\end{array}$ \\
\hline \multicolumn{2}{|c|}{$\begin{array}{l}\text { A MULTI CRITERIA ANALYSIS TO EVALUATE } \\
\text { FUNCTIONING OF PHOTOVOLTAIC POWER PLANTS } \\
\text { IN PAKISTAN }\end{array}$} & $\begin{array}{l}\text { Muhammad Asad (Italy) }{ }^{1} \text {, Antonella Petrillo (Italy) }{ }^{2} \text {, Fabio De } \\
\text { Felice (Italy) }{ }^{3} \text { (1. Department of Engineering - University of Naples } \\
\text { "Parthenope", Italy, 2. Department of Engineering - University of } \\
\text { Naples "Parthenope", 3. Cassino and Southern Lazio, Italy) }\end{array}$ \\
\hline \multicolumn{3}{|c|}{ SATURDAY 1:05pm } \\
\hline Zoom POS2 & $\begin{array}{l}\text { Poster Session } 2 \\
\text { Prof. Antonella Petrillo (Italy) }\end{array}$ & Department of Engineering - University of Naples "Parthenope” \\
\hline \multicolumn{2}{|c|}{ TOTAL DECISION SOFTWARE } & $\begin{array}{l}\text { Daniel Villa (Chile) }{ }^{1}, \text { Claudio Garuti }(\text { Chile })^{1}(1 . \text { Fulcrum } \\
\text { Engeneering) }\end{array}$ \\
\hline \multicolumn{2}{|c|}{$\begin{array}{l}\text { AHP FOR EVERYBODY: INNOVATION THROUGH } \\
\text { MOBILE APPLICATION FOR PERSONAL DECISIONS }\end{array}$} & $\begin{array}{l}\text { Sovit Poudel (Nepal) }{ }^{1} \text {, Shashi Bhattarai (Nepal) }{ }^{2} \text { (1. Truenary } \\
\text { Solutions, 2. Knowledge Holding International) }\end{array}$ \\
\hline \multicolumn{2}{|c|}{$\begin{array}{l}\text { SCHOOL AND ACADEMIC PERFORMANCE: SOME } \\
\text { EVIDENCE FROM ITALY }\end{array}$} & $\begin{array}{l}\left.\text { Antonella Ferraro (Italy) }{ }^{1}, \text { Paola Mancini (Italy }\right)^{1}, \text { Gabriella } \\
\text { Marcarelli (Italy })^{1}(1 . \text { University of Sannio) }\end{array}$ \\
\hline \multicolumn{2}{|c|}{$\begin{array}{l}\text { COMPARISON OF THE APPLICATION OF } \\
\text { PRODUCTION MANAGEMENT TOOLS AND TOPSIS- } \\
\text { AHP METHODS: BEARING MAINTENANCE PROCESS }\end{array}$} & 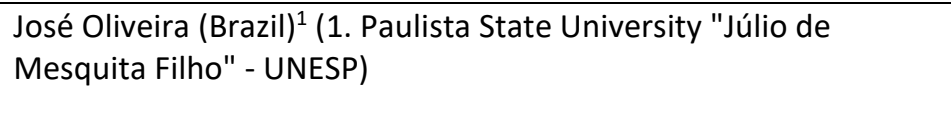 \\
\hline
\end{tabular}




\section{SUNDAY DECEMBER 6 - BREAK OUT SESSIONS}

\section{SUNDAY 8:05 am}

\begin{tabular}{l|l} 
Zoom SU_T2_S4 & $\begin{array}{l}\text { Track } 2 \text { - Session } 4 \\
\text { Cigdem Kadaifci }\end{array}$
\end{tabular}

APPLYING THE ANALYTIC HIERARCHY PROCESS IN

FACULTY SEARCH

Carlo Smith (United States) ${ }^{1}$, Ozden Bayazit (United States) ${ }^{1}(1$.

Central Washington University)

ANALYSIS OF THE TECHNICAL AND ECONOMIC FEASIBILITY OF USING ELECTRIC PROPULSION IN BRAZILIAN NAVY PASSENGER TRANSPORT VESSELS: AN APPROACH OF AHP METHOD

STRATEGIC PRIORITIES OF THE RELIGIOUS INSTITUTION USING COMBINATION OF SWOT AND FUZZY-AHP. CASE STUDY OF THE CONGREGATION OF MISSIONARIES OF THE SACRED HEART

SÉRGIO MITIHIRO DO NASCIMENTO MAÊDA (Brazil) ${ }^{1}$, Igor Pinheiro de Araújo Costa (Brazil) ${ }^{1}$, Luiz Frederico Horácio de Souza de Barros Teixeira (Brazil) ${ }^{3}$, Carlos Francisco Simões Gomes (Brazil) $^{1}$, Marcos dos Santos (Brazil) ${ }^{5}$, Marcos Alexandre Pinto de Castro Junior (Brazil) ${ }^{6}$, Arthur Pinheiro de Araújo Costa (Brazil) ${ }^{7}$, José Victor de Pina Corriça (Brazil) ${ }^{7}$ (1. Universidade Federal Fluminense (UFF), 2. Centro de Análises de Sistemas Navais (CASNAV), 3. Instituto Militar de Engenharia (IME), 4. Pontifícia Universidade Católica (PUC), 5. Marinha do Brasil) Jozef Raco (Indonesia) ${ }^{1}$, Johanis Ohoitimur (Indonesia) ${ }^{2}$, James Krejci (United States) ${ }^{3}$, yulius raton (Indonesia) ${ }^{1}$, Anselmus Jamlean (Indonesia) ${ }^{2}$, Ignasius Welerubun (Indonesia) ${ }^{2}$, Rafael Tanod (Indonesia) ${ }^{1}$ (1. Universitas Katolik De La Salle Manado, 2. Sekolah Tinggi Filsafat Seminari Pineleng, 3. Lewis University) 


\begin{tabular}{|c|c|c|}
\hline \multicolumn{2}{|c|}{$\begin{array}{l}\text { SELECTION OF MEDICAL WASTE TREATMENT } \\
\text { CENTERS USING ANP }\end{array}$} & $\begin{array}{l}\text { Xin Li (China) })^{1} \text {, Xi Chen }(\text { China) })^{1} \text {, Mujgan Sagir (Turkey) }{ }^{3} \text { (1. Xidian } \\
\text { University, 2. Eskisehir Osmangazi University) }\end{array}$ \\
\hline \multicolumn{2}{|c|}{$\begin{array}{l}\text { MODEL TO DETERMINE THE INVESTMENT PRIORITY } \\
\text { FOR TELECONTROLLED FACILITIES IN SANITARY } \\
\text { INDUSTRY IN CHILE TO ADAPT TO CLIMATE CHANGE }\end{array}$} & $\begin{array}{l}\text { Claudio Macuada }(\text { Chile })^{1}, \text { Astrid Oddershede }(\text { Chile })^{1}, \text { Luis } \\
\text { Quezada }(\text { Chile })^{1}, \text { Pedro Palominos }(\text { Chile })^{1}(1 . \text { University of } \\
\text { Santiago of Chile) }\end{array}$ \\
\hline \multicolumn{2}{|c|}{$\begin{array}{l}\text { AHP- BASED SOCIAL VULNERABILITY INDEX FOR } \\
\text { SMALL FISHERIES IN YUCATAN, MEXICO }\end{array}$} & $\begin{array}{l}\text { Tatiana Merino (Mexico) }{ }^{1} \text {, lleana Grave (Mexico) }{ }^{2} \text {, Luis Antonio } \\
\text { Bojórquez-Tapia (Mexico) }{ }^{2} \text { (1. Posgrado en Ciencias de la } \\
\text { Sostenibilidad, UNAM, 2. Laboratorio Nacional de Ciencias de la } \\
\text { Sostenibilidad, Instituto de Ecología, UNAM) }\end{array}$ \\
\hline \multicolumn{3}{|l|}{ SUNDAY 9:05 am } \\
\hline Zoom SU_T1_S5 & \multicolumn{2}{|c|}{$\begin{array}{l}\text { Track } 1 \text { - Session } 5 \\
\text { Prof. Luis Vargas (United States) - University of Pittsburgh }\end{array}$} \\
\hline \multicolumn{2}{|c|}{$\begin{array}{l}\text { WEIGHTED AVERAGE VS TOPSIS: A COMPARISON OF } \\
\text { AGGREGATION METHODOLOGIES FOR AHP }\end{array}$} & 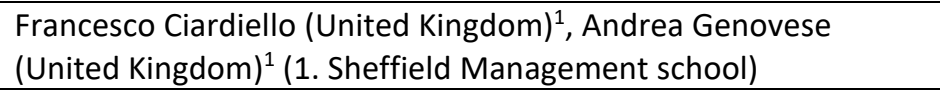 \\
\hline \multicolumn{2}{|c|}{$\begin{array}{l}\text { EXTENSION OF THE AHP METHOD TO GROUP } \\
\text { DECISION-MAKING FOR DETERMINING THE BEST } \\
\text { CARE CENTER OF SEVERE CASES OF COVID-19 IN } \\
\text { OUAGADOUGOU/BURKINA FASO: THE CASE OF } \\
\text { THREE DECISION MAKERS. }\end{array}$} & $\begin{array}{l}\text { Zoïnabo Savadogo (Burkina Faso) }{ }^{1} \text {, Frédéric NIKIEMA (Burkina } \\
\text { Faso) }^{2} \text {, Somdouda SAWADOGO (Burkina Faso) }{ }^{3} \text {, Blaise SOME } \\
\text { (Burkina Faso) }^{2} \text { (1. university of Joseph Ki-Zerbo, 2. Université } \\
\text { Joseph KI-ZERBO, 3. Institut Des Sciences (IDS)) }\end{array}$ \\
\hline \multicolumn{2}{|c|}{$\begin{array}{l}\text { TRANSMISSION LINE ROUTING USING GIS TOOLS OF } \\
\text { SPATIAL SCIENCES }\end{array}$} & $\begin{array}{l}\left.\text { Nawa Raj Chapagain (Nepal) }{ }^{1} \text {, Subrat Subedi (Nepal) }\right)^{1}, \text { Neha Joshi } \\
(\text { Nepal) })^{1}, \text { Bibek Rai }\left(\text { Nepal) }{ }^{1}, \text { Binay Paudyal }\left(\text { Nepal) }{ }^{1}, \text { Ashish Regmi }\right.\right. \\
(\text { Nepal) })^{1}, \text { Rajiv Bishwokarma }(\text { Nepal })^{1}, \text { Saroj Ghimire }(\text { Nepal })^{1},\end{array}$ \\
\hline
\end{tabular}




\begin{tabular}{|c|c|c|}
\hline & & $\begin{array}{l}\text { Komal Atreya (Nepal) }{ }^{9} \text { (1. NEA Engineering Company Limited, } 2 . \\
\text { Nepal Electricity Authority) }\end{array}$ \\
\hline Zoom SU_T5_S2 & \multicolumn{2}{|l|}{$\begin{array}{l}\text { Track } 5 \text { - Session } 2 \\
\text { Mario Sandoval }\end{array}$} \\
\hline \multicolumn{2}{|c|}{$\begin{array}{l}\text { EVALUATING THE EFFECT OF ORGANIZATIONAL } \\
\text { MINDFULNESS IN HEALTH ORGANIZATIONS IN } \\
\text { COLOMBIA }\end{array}$} & $\begin{array}{l}\text { Yuli Leon (Colombia) }{ }^{1} \text {, Enrique Mu (United States) }{ }^{2} \text { (1. University } \\
\text { of Rosario, 2. Carlow University) }\end{array}$ \\
\hline \multicolumn{2}{|c|}{$\begin{array}{l}\text { SELECTION OF BEST HOSPITAL FOR KIDNEY } \\
\text { TRANSPLANTATION USING AHP: A CASE FOR TURKEY }\end{array}$} & $\begin{array}{l}\left.\text { Fatma Kutlu Gündoğdu (Turkey) }{ }^{1} \text {, Ali Karasan (Turkey) }\right)^{2} \text { (1. } \\
\text { National Defence University, 2. Yildiz Technical University) }\end{array}$ \\
\hline \multicolumn{2}{|c|}{$\begin{array}{l}\text { FUZZY AHP MODEL TO SUPPLIER PERFORMANCE } \\
\text { EVALUATION IN PUBLIC INSTITUTIONS }\end{array}$} & $\begin{array}{l}\text { Juliana Leyton (Colombia) }{ }^{1} \text {, Juan Osorio (Colombia) }{ }^{1}(1 . \\
\text { Universidad del Valle) }\end{array}$ \\
\hline \multicolumn{3}{|c|}{ SUNDAY 11:05 am } \\
\hline Zoom SU_T3_S2 & \multicolumn{2}{|l|}{$\begin{array}{l}\text { Track } 3 \text { - Session } 2 \\
\text { Azilah Anis (Malaysia) }\end{array}$} \\
\hline \multicolumn{2}{|c|}{$\begin{array}{l}\text { DISPATCH PRIORITIZATION IN AN AGRICULTURAL } \\
\text { FERTILIZER COMPANY USING AHP AND TOPSIS }\end{array}$} & $\begin{array}{l}\text { Jorge Rojas (Colombia) }{ }^{1} \text {, Juan Osorio (Colombia) }{ }^{1} \text { (1. Universidad } \\
\text { del Valle) }\end{array}$ \\
\hline
\end{tabular}




\begin{tabular}{|c|c|c|}
\hline \multicolumn{2}{|c|}{$\begin{array}{l}\text { SUPPLIER SELECTION USING AHP AND TOPSIS IN } \\
\text { FOOD COMPANIES CONSIDERING OPERATIONAL } \\
\text { RISK }\end{array}$} & $\begin{array}{l}\text { Jenny Hurtado (Colombia) })^{1} \text {, Katherine Hurtado }(\text { Colombia })^{1} \text {, Juan } \\
\text { Osorio (Colombia) }{ }^{1} \text {, Carolina Lima }(\text { Colombia })^{1}(1 \text {. Universidad del } \\
\text { Valle) }\end{array}$ \\
\hline \multicolumn{2}{|c|}{$\begin{array}{l}\text { THE ANALYTIC HIERARCHY PROCESS: APPLICATION } \\
\text { TO THE SELECTION OF THE BEST E-WALLET IN } \\
\text { KLANG VALLEY, MALAYSIA. }\end{array}$} & $\begin{array}{l}\text { Rajan Amaloo (Malaysia) }{ }^{1} \text { (1. Department of Business } \\
\text { Administration, International Islamic University Malaysia) }\end{array}$ \\
\hline Zoom SUN_APPS & \multicolumn{2}{|c|}{$\begin{array}{l}\text { AHP Applications } \\
\text { Rozann Saaty (United States) - Creative Decisions Foundation }\end{array}$} \\
\hline \multicolumn{2}{|c|}{$\begin{array}{l}\text { A MCDM MODEL FOR MEASURING THE } \\
\text { PREPAREDNESS LEVEL OF SALES DEPARTMENTS IN } \\
\text { COVID-19 AND FUTURE PANDEMICS: ELECTRICAL } \\
\text { APPLIANCE SECTOR }\end{array}$} & $\begin{array}{l}\text { Miguel Ortíz-Barrios (Colombia) }{ }^{1} \text {, Iván-Darío Gómez-Villar } \\
\text { (Colombia) }^{2}, \text { Arlen Borrego-Areyanes (Colombia) } \\
\text { Petrillo (Italy) }{ }^{4} \text { (1. Department of Productivity and Innovation, } \\
\text { Universidad de la Costa CUC, Barranquilla, 2. Department of } \\
\text { Business Administration, Universidad de la Costa CUC, } \\
\text { Barranquilla, 3. Department of Business Administration, } \\
\text { Universidad de la Costa CUC, Barranquilla, 4. Department of } \\
\text { Engineering - University of Naples "Parthenope") }\end{array}$ \\
\hline \multicolumn{2}{|c|}{$\begin{array}{l}\text { DETERMINING CRITERIA AND SUB-CRITERIA } \\
\text { WEIGHTS FOR THE SELECTION OF REGIONAL } \\
\text { CENTERS OF COMPETENCE IN CROATIA }\end{array}$} & $\begin{array}{l}\text { Bojan Zugec }(\text { Croatia })^{1} \text {, Blazenka Divjak (Croatia) }{ }^{2} \text {, Nina Begicevic } \\
\text { Redjep (Croatia) }{ }^{2}(1 \text {. Universty of Zagreb, Faculty of organization } \\
\text { and informatics, } 2 \text {. University of Zagreb, Faculty of organization } \\
\text { and informatics) }\end{array}$ \\
\hline \multicolumn{2}{|c|}{$\begin{array}{l}\text { AHP FOR LAND VALUATION IN LAND ACQUISITION } \\
\text { FOR INFRASTRUCTURE DEVELOPMENT }\end{array}$} & Subash Ghimire (Nepal) ${ }^{1}$ (1. Kathmandu University) \\
\hline
\end{tabular}




\begin{tabular}{|c|c|c|}
\hline Zoom SU_T4_S1 & \multicolumn{2}{|c|}{$\begin{array}{l}\text { Track } 4 \text { - Session } 1 \\
\text { Prof. Alessio Ishizaka (France) - NEOMA Business School }\end{array}$} \\
\hline \multicolumn{2}{|c|}{$\begin{array}{l}\text { APPLICATION OF THE AHP-TOPSIS-2N HYBRID } \\
\text { METHOD FOR SELECTION OF AN ATTACK } \\
\text { HELICOPTER TO BE ACQUIRED BY THE BRAZILIAN } \\
\text { NAVY }\end{array}$} & $\begin{array}{l}\text { Igor Pinheiro de Araújo Costa (Brazil) }{ }^{1} \text {, Marcos Alexandre Pinto de } \\
\text { Castro Junior (Brazil)², SÉRGIO MITIHIRO DO NASCIMENTO } \\
\text { MAÊDA (Brazil) }{ }^{1} \text {, Luiz Paulo Fávero (Brazil) }{ }^{4} \text {, Arthur Pinheiro de } \\
\text { Araújo Costa (Brazil) }{ }^{5} \text {, José Victor de Pina Corriça (Brazil) }{ }^{5} \text {, Carlos } \\
\text { Francisco Simões Gomes (Brazil) }{ }^{1} \text {, Marcos dos Santos }(B r a z i l){ }^{8}(1 . \\
\text { Universidade Federal Fluminense (UFF), 2. Pontifícia Universidade } \\
\text { Católica (PUC), 3. Universidade de São Paulo (USP), 4. Marinha do } \\
\text { Brasil, 5. Instituto Militar de Engenharia (IME)) }\end{array}$ \\
\hline \multicolumn{2}{|c|}{$\begin{array}{l}\text { EVALUATION OF KEY TECHNOLOGICAL TOOLS IN } \\
\text { TERMS OF SUPPLY CHAIN SUSTAINABILITY IN THE } \\
\text { DIGITALIZATION ERA WITH DIFFERENT ANALYTIC } \\
\text { HIERARCHY PROCESS METHODS }\end{array}$} & $\begin{array}{l}\left.\text { ABDULLAH YILDIZBASI (Turkey) }{ }^{1} \text {, Cihat OZTURK (Turkey) }\right)^{1} \text {, Sachin } \\
\text { Kumar MANGLA (United Kingdom) }{ }^{3} \text {, Yiğit KAZANCOGLU (Turkey) } \\
\text { (1. Ankara Yıldırım Beyazıt University, 2. University of Plymouth, } \\
\text { 3. Yaşar University) }\end{array}$ \\
\hline \multicolumn{2}{|c|}{$\begin{array}{l}\text { USING AHP AND QFD IN THE INVESTIGATION AND } \\
\text { REFINEMENT OF E-BANKING SERVICES }\end{array}$} & $\begin{array}{l}\text { Georgios Paltayian (Greece) }{ }^{1}, \text { Andreas Georgiou (Greece) }{ }^{1}, \\
\text { Katerina Gotzamani (Greece) })^{1}(1 . \text { University of Macedonia) }\end{array}$ \\
\hline
\end{tabular}




\section{PROGRAM SCHEDULE WITH ABSTRACTS}

\section{THURSDAY DECEMBER 3}

\section{WORKSHOP 1: SENSITIVITY ANALYSIS}

8:05 am

\section{Room: Zoom Workshop Room 1}

Great, we synthesized our model and have a final ranking! But we aren't quite done yet. How robust is the decision? Which criteria are most important or influential? What would happen if "this" or "this" criterion had been weighted differently? Would it even make a difference in the final outcome? Sensitivity analysis is an important component in the decision making process. The findings from the sensitivity analysis can be just as important as the final ranking.

This session is organized into 3 sections:

1) Understanding the Supermatrix and aggregation process is key to doing good sensitivity analysis - we will move from an unweighted Supermatrix to the final ranking in a complex model.

2) We will use some of the great tools provided within Super Decisions to do sensitivity analysis.

3) We will use an exported model to do sensitivity analysis in Excel.

Presenter: Dr. Orrin Cooper (United States) - University of Memphis

\section{WORKSHOP 2: HOW TO CONDUCT A NEGOTIATION USING AHP}

9:05 am

\section{Room: Zoom Workshop Room 2}


In this workshop we will try to show you how to conduct a negotiation using the Analytic Hierarchy Process. This approach is an extension of the "Getting to Yes" approach where parties do not see each other as adversaries, but as teams looking for a fair and equitable solution to the conflict. The workshop will address the following concepts:

1. What is a negotiation?

2. Dimensions of a negotiation

3. The concept of a tradeoff

4. How to evaluate a tradeoff

5. Gain/loss ratios of tradeoffs. When is a tradeoff fair and equitable?

6. An agreement as a conglomerate of fair and equitable tradeoffs

7. Implementation of a fair agreement.

The workshop will use some well-known negotiation situations, not necessarily conflict resolution negotiations, to illustrate the different steps of the process.

Presenter: Prof. Luis Vargas (United States) - University of Pittsburgh

\section{WORKSHOP 3: HOW TO IMPROVE YOUR CHANCE OF GETTING} YOUR AHP/ANP

10:05 am

\section{Room: The Pool Zoom Workshop Room 3}

This workshop is aimed at scholars in the early or middle phase of their professional careers who are interested in getting their AHP/ANP papers published. It focuses, in particular, on AHP/ANP applications. These applications, per se, are usually hard to publish. Based on the lecturer's experience as author, editor and reviewer of many of these application papers, some practical suggestions will be given to the participants.

Presenter: Dr. Enrique Mu (United States) - Carlow University 


\section{WORKSHOP 4: THE HOW AND WHYS OF ANP ROW SENSITIVITY}

\section{1:05 am}

\section{Room: Zoom Workshop Room 4}

After an ANP model is created and yields synthesized values for the alternatives we would like to understand how the structure of the model effects the results of the model. In traditional AHP models we can use sensitivity to increase or decrease the importance of a given node and see how the alternatives change. By using ANP row sensitivity we can perform a similar analysis on ANP models.

In this workshop you will learn how to use ANP row sensitivity and what calculations hide behind the results. You will learn how to calculate stepby-step ANP row sensitivity using either an Excel spreadsheet or Super Decisions. Even more important, you will see how to interpret the ANP row sensitivity results and how to use them to evaluate the model and the results.

Presenter: Dr. William Adams (United States) - Decision Lens

\section{AHP WORKSHOP 5: BENEFITS-OPPORTUNITIES-COSTS AND RISKS CALCULATIONS DEMYSTIFIED}

\section{2:05 pm}

\section{Room: Zoom Workshop Room 5}

A full BOCR analysis is in some ways like a SWOT analysis, where not only the strengths (S) and weaknesses (W) of an organization are taken into consideration but also its opportunities $(\mathrm{O})$ and threats $(\mathrm{T})$. Similarly, in an ANP BOCR analysis we have the expected benefits, opportunities, costs, and risks of a decision.

In this workshop we will see what questions to ask to define the strategic criteria, control criteria and sub-nets. We will focus on how we gather the local results and synthesize them in a bottom-up approach to get the final results. We will talk about the meaning of the multiplicative formula and the additive/negative and when to use each of them? 
Presenter: Dr. Elena Rokou - Creative Decisions Foundation 


\section{WORKSHOP 6: MEETING FACILITATION}

\section{1:05 pm}

\section{Room: Zoom Workshop Room6}

To support effective group decision making, it is necessary to foster a productive collaborative environment. This session will focus on meeting facilitation tools designed to enable groups to efficiently and effectively collaborate towards making decisions with AHP and ANP. Tools such as an agenda, meeting objective, ground rules, a parking lot, and a clear definition of consensus enable a facilitator to keep teams engaged and focused as they work through building AHP and ANP decision models. Participants will be provided with descriptions of these tools and how they apply to support creating and managing decision frameworks for teams.

Presenter: Mr. Daniel Saaty - Decision Lens 


\section{FRIDAY DECEMBER 4}

\section{WELCOME TO ISAHP 2020}

8:05 am

\section{Room: Zoom WELC}

Speaker:

Dr. Enrique Mu (United States) - Carlow University

Rozann Saaty (United States) - Creative Decisions Foundation

Rozann Saaty, President of Creative Decisions Foundation and Dr Enrique Mu, Chair of the ISAHP 2020 welcome you to the 1st virtual ISAHP conference.

\section{TRACK 1 - SESSION 1}

09:05 am

\section{Room: Zoom FR_T1_S1}

Session Chair: Dr. Anna Florek-Paszkowska - Pontificia Universidad Católica del Perú, Lima, Perú

TRANSFORMING AHP GROUP DECISIONS INTO FUZZY PRIORITIES - A NEW METHODOLOGY TO AGGREGATE INDIVIDUAL PRIORITIES

Oliver Meixner (Austria) ${ }^{1}$, Sonja Hackl (Austria) ${ }^{1}$, Rainer Haas (Austria) ${ }^{1}$ (1. University of Natural Resources and Life Sciences Vienna)

\section{Abstract}

The contribution suggests a new and to our knowledge previously unpublished approach to combine AHP group judgements considering the possible variation of individual AHP evaluations. By introduction fuzzy logic into the group decision process, this approach is appropriate to cover the distribution of individual judgements. The paper will present in brief the theoretical foundation of our approach. Afterwards, we will use an empirical example to test the methodology. For this purpose, we use 
data of a previously conducted survey, where an expert group evaluated the sustainability of palm oil by means of a comprehensive AHP model.

\section{AN UPDATE ON COMBINATORIAL METHOD FOR AGGREGATION OF EXPERT JUDGMENTS IN AHP}

Sergii Kadenko (Ukraine) ${ }^{1}$, Vitaliy Tsyganok (Ukraine) ${ }^{1}$ (1. Institute for Information Recording of the National Academy of Scienes of Ukraine)

\section{Abstract}

The paper covers the recent research of two versions of combinatorial method of deriving individual and group priorities from pair-wise comparison matrices (PCM). The method is based on enumeration of all possible basic sets of pair-wise comparisons (PC) from a given PCM and calculation of average priorities across all of them. In our paper we briefly describe the modified version of the method, which, in contrast to ordinary version, considers consistency, compatibility, and detail of expert data, and (if necessary) provides opportunities for expert data quality improvement.

\section{VECTOR COMPRESSION METHOD TO CONVERT THE INCOMPLETE MATRIX OF PAIRWISE COMPARISONS IN THE ANALYTIC HIERARCHY PROCESS}

Alexander Bochkov (Russian Federation)1, Alexandra Ridley (Russian Federation)2, Nataliya Kuzmina (Russian Federation) ${ }^{3}$, Nikolay Zhigirev (Russian Federation) ${ }^{4}$ (1. JSC NIIAS, 2. Moscow Aviation Institute (National Research University), 3. Moscow State Technical University of Civil Aviation, 4. KALABI IT)

\section{Abstract}

AHP is one of the most popular decision-making procedures due to its efficiency, flexibility and simplicity. Its main disadvantage is the inability to formalize incomplete or inaccurate comparisons of alternatives with each other. Missed assessments make it difficult to make decisions because most statistical methods do not apply to incomplete data sets. A popular classical algorithm for matrices of pairwise comparison processing cannot work with matrices containing predominantly zero components. The purpose of the work is to develop a method for expert 
assessments matrices processing in order to obtain weight coefficients (weights) of considered alternatives, which allow quantitative comparisons. The matrix of pairwise comparison is considered as a spanning graph in which compared alternatives are nodes and comparisons are edges. Here it is proposed a method of removing edges corresponding to the most controversial values, that is, a cycle break algorithm that causes the convert of the original graph into a spanning tree and allows uniquely comparing any two alternatives.

\section{TRACK 6 - SESSION 1}

9:05am

\section{Room: Zoom FR_T6_S1}

Sessison Chair: Dr. Monica Garcia Melon (Spain) - Ingenio (CSICUPV)

BUSINESSES AS SOCIAL PARTNERS IN GENDER POLICIES: ASSESSMENT OF THE ACTORS' EXPECTATIONS TO CONTRIBUTE TO GENDER EQUALITY

Paula Otero-Hermida (Spain)1, Hannia Gonzalez-Urango (Spain) ${ }^{2}$ (1. Ingenio (CSIC-UPV), 2. Ingenio (CSIC-UPV), Universitat Politècnica de València)

\section{Abstract}

Businesses tend to be the target of policies due to their rare commitment to matters concerning equality, although new governance guidelines in the gender mainstreaming strategy propose more active participation on their part. This study explores the use of AHP in the case of Colombian to understand more about this conflicting scenario and a potential new business role. This research focuses on the expectations of businesses committed to corporate social responsibility and expectations of other conventional policy actors (government, equality organizations, and academia) with respect to businesses. The results reveal a possible role shift towards businesses in more active positions and also possible misunderstandings arising from divergent expectations. The AHP was useful for detecting various role gaps in business self-concept and the 
perception of other actors with regards to potential capabilities contributing to the policies.

\section{A TOOL FOR MONITORING THE UNDER REPRESENTATION OF WOMEN IN CONFERENCES AND EVENTS}

Carmen Corona-Sobrino (Spain) $)^{1},(\text { Spain) })^{2}$, Rocío Poveda-Bautista (Spain)2, Hannia Gonzalez-Urango (Spain) ${ }^{2}$ (1. Ingenio (CSIC-UPV), Universitat Politècnica de València; Departamento Sociologia I Universidad de Alicante, 2. Ingenio (CSIC-UPV), Universitat Politècnica de València)

\section{Abstract}

The importance of participation in conferences and events is well known for members of the society. It is not only for the feedback and the personal experience, it is also about career development, building networks and increasing visibility. Nevertheless, women continue to be under-represented in these events and even more so in the most visible positions such as speaking roles. This paper presents the development of a tool based on performance indicators, which will allow monitoring and evaluating gender roles and inequalities in conferences and events in order to tackle the underrepresentation of women. The study identifies relevant perspectives (participation, organizational structure and attitudes) and designs specific lists of performance indicators for each of them. The tool is based on a combination of two multicriteria techniques, Analytic Hierarchy Process and Analytic Hierarchy Process Sort, and a qualitative analysis based on in-depth interviews and information gathered from focus groups. The use of the AHP multi-criteria decision technique has allowed us to weight the indicators according to the opinion of several experts, and with them to be able to generate from these weightings composite indicators for each of the three dimensions. The most relevant indicators were for the participation dimension. Additionally, the tool developed has been applied to a conference which has been monitored in real time. The results are shown as a traffic light visualization approach, where red means bad performance, yellow average performance and green good performance, helping us to present the results for each indicator. Finally, proposals for improvement actions addressed to the red indicators are explained. The work carried out highlights the need to broaden the study of gender equality in 
conferences and events, not only regarding the participation but also the performance of different roles and functions.

\section{ANPSORT II METHOD: AN EXPERIMENTATION TO ASSESS THE RESILIENCE OF A SOCIO-ECOLOGICAL SYSTEM}

Vanessa Assumma (Italy)1, Marta Bottero (Italy) ${ }^{1}$, Alessio Ishizaka (France) $^{3}$ (1. Polytechnic University of Turin, 2. NEOMA Business School)

\section{Abstract}

In the current context of climate change, Decision Makers are ever more interested to use multidisciplinary and interdisciplinary approaches to support the practice of resilience thinking within long-term strategies. This paper presents an experimentation of a Multicriteria Decision Analysis approach (MCDA) developed through the Analytic Network Process Sorting II method (ANPSort II) to investigate the resilience of a Socio-Ecological Systems as a group of territorial clusters in the Grand-Est region, France. A set of indicators was defined to evaluate the resilience of territorial clusters, according to analyses performed through GIS and STEEP+SWOT Analysis. A survey was developed to investigate the importance of the set of indicators and to assess the resilience performance of the case study under investigation. The assessment was represented into a GIS spatial map to aid the visualization of the final classification. The ANPSort II method may be considered a very promising evaluation procedure to aid planners and Decision Makers to envision scenarios of territorial transformation for the planning of more sustainable and resilient cities and territories.

\section{KEYNOTE SPEAKER: LEADERSHIP IN COMPLEX AND CHAOTIC} SITUATIONS

10:05 am

\section{Room: Zoom KEY1}

Presenter: Dr. Blaženka Divjak (Croatia) - University of Zagreb, Faculty of organization and informatics 


\section{TRACK 2 - SESSION 1}

\section{1:05am}

\section{Room: Zoom FR_T2_S1}

Session Chair: Ilker Topcu (Turkey) - istanbul technical university

\section{A MULTI-ATTRIBUTE DECISION MAKING MODEL FOR HOSPITAL LOCATION SELECTION}

Gül Imamoğlu (Turkey)1, Ilker Topcu (Turkey) ${ }^{2}$ (1. Karadeniz Technical University, 2. istanbul technical university)

\section{Abstract}

Demand for the healthcare sector is increasing day by day because of facts such as population growth, increase in average human lifespan, changing eating habits and the rapid spread of epidemics in large areas. To meet the demand increase in the health sector and to reach high standards in the health sector, new hospitals are being established in Turkey. Therefore, the selection of hospital location arises as an important decision problem. In case of an inaccurate hospital location selection, besides a large monetary load, loss of human life may occur. For this reason, hospital location selection should be treated by analytical and rational methods. For this purpose, in this study, a hybrid MultiAttribute Decision Making model in which importance of attributes are determined using Analytic Network Process(ANP) method and evaluation of alternatives is carried out using PROMETHEE method is proposed. As a case study, the proposed model is utilized to make a suitable location selection for a hospital in Trabzon province of Turkey.

\section{UNCERTAINTY AND COMPATIBILITY IN AHP MODELING: CONSENSUS BUILDING IN PROJECT PORTFOLIO FORMULATION FOR MULTILATERAL ORGANIZATIONS}

lleana Grave (Mexico) ${ }^{1}$, Paola Gómez-Priego (Mexico) ${ }^{1}$, Luis Antonio Bojórquez-Tapia (Mexico) ${ }^{3}$ (1. Laboratorio Nacional de Ciencias de la Sostenibilidad, 2. Laboratorio Nacional de Ciencias de la Sostenibilidad, Instituto de Ecología, UNAM)

\section{Abstract}


Here we address the practical problem of creating optimal project portfolios for a multilateral organization such as the Global Environmental Facility (GEF). Experience shows that crafting these portfolios can be a challenging and controversial task. Hence, one prerequisite of GEF project portfolios is ensuring the civil society stakeholders' and the academic community's broad participation in evaluating and selecting projects. We develop a framework to evaluate and select the 2014-2018 Mexico's GEF project portfolio. We thus applied the AHP and sensitivity analysis to constructively engage a large group $(n=80)$ of civil society and academia representatives. Results demonstrate that sensitivity analysis is fundamental for settling debates, building consensus, and achieving transparent and technically defensible project portfolios.

NEUTROSOPHIC ANALYTIC HIERARCHY PROCESS FOR EVALUATING A NEW SERVICIZING BUSINESS MODEL OF TRANSPORTATION

Saliha Karadayi-Usta (Turkey) ${ }^{1}$ (1. Fenerbahce University)

\section{Abstract}

The new normal of the world has been shaped by the COVID-19 pandemics. It has made compulsory to avoid public transportation and to provide individual transportation in order to prevent the spread of the disease. Due to the high financial burden of purchasing a car, new business models have been developed in order to make possible of utilizing vehicles to meet the transportation needs in pay-per-use base. The concept called "servicizing business model" or "servicization" is based on presenting a product as a service, and selling the functionality of that product instead of the product itself. In order to meet the increasing demand for individual vehicle use, the existing car rental service providers have provided a new mobile application controlled business model which makes the rental process easier, by determining the location of the available vehicle via the applications, opening the vehicle without a key by GPS signals through the application, and making the payment from the previously defined credit card according to the duration of driving. The aim of this study is to evaluate the customers' preferences of purchasing, renting through an agency, or mobile 
application supported new pay-as-you-go business model use, in order to determine which criterion is prominent in the decision-making process, and to identify the weights of these criteria. Due to the uncertain and indeterminate attitudes of the customers in decision making, the data were collected as neutrosophic data sets and analyzed with a novel neutrosophic Analytic Hierarchy Process (nAHP) approach. The study provides implications both theoretically and practically in terms of revealing new servicization possibilities and analyzing real user judgments.

\section{TRACK 3 - SESSION 1}

\section{1:05am}

\section{Room: Zoom FR_T3 S1}

Session Chair: Prof. Rafikul Islam (Malaysia) - Department of Business Administration, International Islamic University Malaysia

\section{LAYOUT ASSESSMENT WITH STRUCTURING AND MATHEMATICAL MODELING BY THE AHP METHOD}

Lucas Ramon dos Hermogenes (Brazil) ${ }^{1}$, Miguel Moreira (Brazil) $)^{1}$, Lorena Berzins (Brazil) $)^{3}$, Marcos dos Santos (Brazil) ${ }^{1}$ (1. Instituto Militar de Engenharia (IME), 2. Fundação Getúlio Vargas (FGV))

\section{Abstract}

This present paper describes the decision processes with AHP method to choose between two alternatives that could improve the production performance of a galvanized duct manufacturing company. Its manufacturing line layout appears to be the constraints of production to attend the market demand. After structuring and analyzing the preferences and values under a criteria set evaluation, the most favorable layout promises to deliver cost reduction, technology improvement and better production performance. Although the web computational platform 3 Decision Methods (3decisionmethods.com) supported the problem modeling, the analysis is described with all 
axiomatic processes with details.

\section{APPLYING AHP TECHNIQUE TO CHOOSE PRODUCT TYPE IN PAPER FACTORIES}

Mohammad Solemani Diarjan (Iran, Islamic Republic of) ${ }^{1}$, Majid Azizi (Iran, Islamic Republic of $)^{1}$ (1. University of Tehran)

\section{Abstract}

One of the substantial concerns of investor in the paper and cardboard industry in order to obtain maximum efficiency \& profit is selecting the right product to manufacture, therefore this study carry on in Iran to avoid manufacturer to make wrong decision cause previously some investor in paper market failed just in case didn't let all major criteria to be considered.

To find out the best product for the paper and cardboard produce in a factory located in the center of Iran in the first stage we ask 20 experts in different filed of paper and cardboard participate in this survey and while we get all respond from them according to Delphi technique we summarize it, arrange second survey and collect all date and obtain all major criteria accepted by all participants.

Then in the second stage we design a AHP framework, ask 10 expert participate in the survey, while we get all respond from them and collect all the data according to the analytic hierarchy process (AHP) technique and usage of Expert choice software by pairwise comparison of each criteria and obtaining the weight of each alternative and analyzing all data we obtain the most profitable alternative to produce to gain most possible profit for the investor.

\section{ENHANCING FINANCIAL AND STRATEGIC PERFORMANCE OF AN OIL AND GAS COMPANY}

Rafikul Islam (Malaysia) ${ }^{1}$, Deven Sharma KRISHNAN (Malaysia) ${ }^{2}$ (1. Department of Business Administration, International Islamic University Malaysia, 2. Graduate School of Management, International Islamic University Malaysia)

\section{Abstract}

The study intends to prioritize the core competencies with respect to 
competitive advantage, financial as well as strategic performance for an oil and gas company in Malaysia. Interviews were conducted to solicit information about the company's core competencies, competitive advantage and financial and strategic performance. The interview findings were used for questionnaire development in order to rank core competencies with respect to competitive advantage, financial and strategic performance. The survey results were analysed using Analytic Hierarchy Process (AHP). The study has set a benchmark for prioritising core competencies, with respect to competitive advantage, financial and strategic performance for oil and gas companies.

\section{TRACK 1 - SESSION 2}

\section{$12: 05 p m$}

\section{Room: Zoom FR_T1_S2}

Session Chair: José María Moreno-Jiménez (Spain)

\section{NOTES ON THE USE OF COMPATIBILITY INDEX IN THE ANALYTIC HIERARCHY PROCESS}

MinSuk YOON (Korea, Republic of) ${ }^{1}$ (1. Electronic Commerce, Chonnam National University)

\section{Abstract}

This study is composed of 3 notes associated with use and interpretation of the Compatibility [Similarity] Index (S.I.) in the AHP. Compatibility concerns how much two sets of priorities are mutually close. (A) a case is introduced to show that inconsistency in pairwise comparisons can detrimentally effect on measuring the compatibility between the two matrices. In order to avoid such errancy, we remind readers of the meaning of Saaty's compatibility metric and of correct usage. (B) originating from Saaty's consistency index for an entire hierarchy, compatibility for an entire hierarchy is derived to generalize the measurement of compatibility. (C) the sensitivity of S.I. is analyzed to figure out stable or unstable base. 


\section{REDUCING THE NUMBER OF EXPERT PAIR-WISE COMPARISONS DURING DECISION SUPPORT USING AHP}

Oleh Andriichuk (Ukraine) ${ }^{1}$, Vitaliy Tsyganok (Ukraine) ${ }^{1}$, Sergii Kadenko (Ukraine) ${ }^{3}$ (1. National Technical University of Ukraine "Igor Sikorsky Kyiv Polytechnic Institute", Institute for Information Recording of National Academy of Sciences of Ukraine, 2. Institute for Information Recording of National Academy of Scienes of Ukraine)

\section{Abstract}

Studies on the reduction of the number of expert pair-wise comparisons during decision support using AHP is extremely relevant, because they allow expert session organizers to save time and reduce the cost of experts' work. Analysis of results of theoretic research of psychophysiological constraints of human mind, that influence credibility of expert estimates, demonstrated the impact of the order of pair-wise comparisons, performed by experts, upon expert session results. We suggest the respective ways of reduction of the number of expert pair-wise comparisons during decision support using AHP, which, at the same time, maintain the required level of expert information credibility.

\section{PRIORITY VECTOR ESTIMATION: CONSISTENCY, COMPATIBILITY, PRECISION}

Stan Lipovetsky (United States) ${ }^{1}$ (1. independent consultant)

\section{Abstract}

Various methods of the priority vector estimation are known in the Analytic Hierarchy Process (AHP). They include the classical eigenproblem method given by Thomas Saaty, developments in least squares and multiplicative approach, robust estimation based on transformation of the pairwise ratios to the shares of preferences, and other approaches. In this paper the priority vectors are completed with validation of data consistency, comparisons of vectors compatibility, and estimation of precision for matrix approximation by vectors. Numerical results for different data sizes and consistency show that the considered methods reveal useful features, are simple and convenient, capable of facilitating 
practical applications of the AHP in solving various multiple-criteria decision making problems.

\section{TRACK 5 - SESSION 1}

\section{$12: 05 p m$}

\section{Room: Zoom FR_T5_S1}

Session Chair: Prof. Claudio Garuti (Chile) - Fulcrum Engeneering

HOW TO ASSIST TO BETTER AND FASTER MEDICAL DIAGNOSES THROUGH MEDICAL SAPIENS WEB PLATFORM

\section{Claudio Garuti (Chile) ${ }^{1}$ (1. Fulcrum Engineering)}

\section{Abstract}

The medical diagnosis error corresponds to any failure or mistake in the patient care process that leads to the lack of a diagnosis, an incorrect or delayed one.

The main reasons for error in medical diagnosis can be grouped into two fundamental pillars: incorrect/inaccurated diagnosis, and lack of information access.

Damage due to errors in medical diagnosis are due to the delay or failure to treat existing conditions or from wrong treatments, mostly associated to unexisting conditions.

Studies carried out in the United States reveal that the average diagnostic error varies from $4 \%$ to $59 \%$, depending on the nature of the disease and the conditions of medical care. Other autopsy studies have shown error rates ranging from $10 \%$ to $14 \%$.

Therefore, information technologies and specifically Health Information Systems (HIS) provide security tools that are widely validated in healthcare practice, but still require significant development and implementation strategies to be finally accepted by physicians.

In contrast, the Medical Sapiens (MS) web platform allows medical diagnosis based on cardinal description of patients' symptoms and signs, under an additive medicine approach (adding information that increases diagnostic certainty). This approach provides, better, easier and faster identification of possible diagnosis. Currently MS is being tested in several clinical centers in Chile. 
MS's most valuable feature is its database which contains detailed assessment of 1,396 disease profiles over 9000+ weighted criteria, derived from 35 AHNP linked models, which in turn are the topographical representation of the human body.

The elements definition within each one of the 35 models (criteria, subcriteria and intensity scales), was carried out in conjunction with a team of medical specialists with a big expertise coming from different universities, plus medicine texts and evidence-based medicine, during four years in stage I and the last two years (2019-20) in stage II.

\section{A DECISION SUPPORT TOOL FOR HOSPITAL PROJECT SUSTAINABILITY EVALUATION}

Carlotta Patrone (Italy) ${ }^{1}$, Antonio G. Latora (Italy) ${ }^{2}$, Roberto Revetria (Italy) ${ }^{3}$ (1. E.O. Ospedali Galliera, 2. Regione Lazio, 3. Università degli Studi di Genova)

\section{Abstract}

This study aims to develop a Decision Support Tool (DST) able to evaluate the sustainability of strategic projects which could be implemented in a hospital context. The applied methodology was based on a double MultiCriteria Decision Analysis realized by the traditional Analytic Hierarchy Process and the more recent Value-Analytic Hierarchy Process. A case study developed in a middle-size Italian hospital from 2016 to 2019 was proposed in order to implement a sustainability index, named normalized Sustainability Group Global Rating, which represents a first effort to define a standard index for hospital project sustainability.

PRIORITIZING HIGH-RISK DISEASES AND NON-TRAUMAMEDIATED DISEASES IN A TRIAGE ON MEDICAL SAPIENS PLATFORM

Kazi Tasnim (United Kingdom) ${ }^{1}$ (1. Student)

\section{Abstract}

Medical diagnosis is an important aspect of patient care. Every year, thousands of patients die as a result of misdiagnosis. Medical Sapiens created a web platform, MS, that diagnoses patients based on symptoms with a higher accuracy than other platforms that have 
already been created. However, Medical Sapiens is looking to go a step farther: to create a web platform, MS2.0, that will prioritize high-risk diseases and non-trauma-mediated diseases in a triage.

For MS2.0, the platform will take into account several overarching factors: pain, location of pain, fever, loss of consciousness, shortness of breath, and loss or alteration of some function. From these, the system will be able to determine, based on the symptoms logged, how to prioritize the diseases in the case of a triage. In order to test this system, MS2.0 looked at 16 high-risk/non-trauma mediated diseases:

1. Myocardial infarction

2. Cerebral vascular accident

3. Thyrotoxic crisis

4. Pulmonary embolism

5. Meningitis / encephalitis

6. Adisonian crisis

7. Profuse upper gastrointestinal bleeding

8. Suicidal Attempt

9. Carbon monoxide poisoning

10. Lower gastrointestinal bleeding

11. Severe asthma

12. Hypertensive crisis

13. Cardiac arrhythmia with hemodynamic compromise

14. Hyperthermia

15. Severe hypothermia

16. Sting $x$ poisonous organism or to which one is allergic (bee, spider, snake, etc).

The overarching questions then go further into analysis of the diseases by asking more probing questions. The answers to these questions are then weighted by the system to prioritize certain medical emergencies over others. For example, for the category of pain, one might ask where the pain occurs, how long has the pain been there, etc. Rankings can be given based on a scale of 1-7, where 1 indicates minimal pain and 7 indicates severe pain. The system then would be able to indicate which patients are having more severe life threatening pains or problems in comparison to others. 


\title{
POSTER SESSION 1
}

\section{1:05 pm}

\section{Room: Zoom POS1}

Session Chair: Dr. Enrique Mu (United States) - Carlow University

\section{BIBLIOMETRIC STUDY ON AHP AND URBAN MOBILITY}

David Ruiz (Brazil) ${ }^{1}$, Fernando Marins (Brazil) ${ }^{1}$, Valerio Salomon (Brazil) (1. Sao Paulo State University)

\section{Abstract}

This work presents a bibliometric study on the Analytic Hierarchy Process (AHP) and urban mobility. We identified important elements, as keywords, with documents indexed in the Scopus database and we mapped relations with VOSviewer. Urban mobility was selected due to its relevance for the economic development. The survey was carried out at the middle of 2020, resulting in 104 documents published from 2015. One major finding is the absence of scientific production relating both AHP and urban mobility.

\section{ADJUSTED INTANGIBILITY-AWARE ASSESSMENT OF THE UTILISATION OF BIOGAS PLANT TECHNOLOGY APPLICATION POTENTIAL}

Grzegorz Ginda (Poland)1, Marta Szyba (Poland) ${ }^{1}$ (1. AGH UST,Cracow, Poland)

\begin{abstract}
Environmental and economic issues make the widespread of the application of renewable and environmentally friendly energy resources tends to be more and more aware necessity amongst societal, selfgovernmental, and governmental circles. Biogas plants are one of the most promising renewable energy resources in Poland. This is because their widespread may result in considerable environmental and economic benefits. Despite, official efforts to support the investments in biogas plants, the widespread of them seems to be rather scarce across the country. There also seem to be considerable differences between
\end{abstract}


Polish regions with this regard. This is why an effort to examine utilisation of actual potential of biogas technology is discussed in the paper. AHP methodology is applied in this regard. A vital AHP methodology enhancement is also proposed to adjust merits of the methodology to declared intangibility awareness.

\section{HOSPITAL AIRCRAFT IN THE FIGHT AGAINST THE} CORONAVIRUS PANDEMIC: STRUCTURING AND MODELING A COMPLEX PROBLEM USING AHP AND VFT METHODS

Igor Pinheiro de Araújo Costa (Brazil) $)^{1}$, Arthur Pinheiro de Araújo Costa (Brazil)2), José Victor de Pina Corriça (Brazil)2, SÉRGIO MITIHIRO DO NASCIMENTO MAÊDA (Brazil)1, Luiz Frederico Horácio de Souza de Barros Teixeira (Brazil) $)^{5}$, Marcos Alexandre Pinto de Castro (Brazil) ${ }^{6}$, Carlos Francisco Simões Gomes (Brazil)1, Marcos dos Santos (Brazil) ${ }^{8}$ (1. Universidade Federal Fluminense (UFF), 2. Marinha do Brasil, 3. Centro de Análises de Sistemas Navais (CASNAV), 4. Pontifícia Universidade Católica (PUC), 5. Instituto Militar de Engenharia (IME))

\section{Abstract}

The COVID-19 pandemic has threatened the capacity of health systems worldwide, with several cities declaring the collapse of the hospital system. In order to find a way to support Brazil in the fight against the pandemic, this paper applied the Analytic Hierarchy Process (AHP) and Value-Focused Thinking (VFT) methods to select the most suitable hospital aircraft to be acquired by the Brazilian government. The airplane would be used in aeromedical evacuations, supporting the fight against the pandemic, especially in cities where there are no more ICU beds available, transporting patients to other locations with greater structure, technological and technical experience. Six models manufactured by Embraer, employed in aeromedical evacuations, were evaluated in the light of operational, technical and commercial criteria. This paper aims to solve a problem of extreme relevance to academia and society, as it contributes to the solution of a problem that affects millions of people in Brazil and worldwide. After the application of the AHP and VFT methods, Legacy 450 aircraft was chosen as the most indicated to be acquired by the Government and used as hospital aircraft in the fight against the pandemic. 


\section{APPLICATIONS OF THE ANALYTIC HIERARCHY PROCESS METHOD IN FORECASTING: A REVIEW OF THE LITERATURE}

Lidiane Cristina Oliveira (Brazil) $)^{1}$, Bruna Cristine Scarduelli Pachecco (Brazil) $)^{1}$, Claudio Luis Piratelli (Brazil) $)^{1}$ (1. University of Araraquara UNIARA)

\section{Abstract}

The Analytic Hierarchy Process - AHP - is a support method to multicriteria decision created by Thomas Saaty in 1980 . Since then, it has been used worldwide for complex decisions in several areas of knowledge, since it allows incorporating qualitative and quantitative criteria. Demand forecasting is the process of anticipating future levels of demand for a company's products and/or services, and it is a challenge to forecast them accurately, due to the variety of information involved. Given the scenario of uncertainty inherent to the forecasting process, some studies adopt the AHP for such a situation. The objective of this research was to identify, describe and analyze scientific articles that used the AHP for forecasting. For this, a research was carried out on the Web of Science and Scopus databases and seventeen articles were found. It was found that $82.35 \%$ of the forecasting studies applied the AHP to support decision making in: pondering and prioritizing information, classifying products, and selecting best mathematical forecasting model. The applications of AHP in demand forecasting were: shipping costs, development of new products, hospitality, water consumption, environmental pollution indexes, electricity consumption, urban traffic, development of the underground space of railway stations and for the management of spare parts. On the other hand, $17.65 \%$ of the studies effectively used the AHP to calculate/adjust the demand forecast in which the application in hospitality and electricity consumption stands out. It was found that from 1987 to 2019 only one article per year was found related to forecasting with AHP, so it is noted that there is still a gap to explore AHP as an appropriate tool to support forecasting in many other areas, such as fashion products of the textile industry. 


\section{SATURDAY DECEMBER 5}

\section{TRACK 2 - SESSION 2}

8:05am

Room: Zoom SA_T2_S2

Session Chair: Cigdem Kadaifci

\section{APPLICATION EXPERIENCE OF THE AHP FOR THE ANTARCTIC ISSUES}

Oleksandr Kuzko (Ukraine) ${ }^{1}$, Mykola Leonov (Ukraine)² (1. Selfemployed, 2. State Institution National Antarctic Scientific Center of Ukraine)

\section{Abstract}

Presentation is devoted to the application of the Analytic Hierarchy Process (AHP) to obtain solutions for current challenges in such important areas of decision-making as the activity both in Antarctic and in Antarctic Treaty System.

As a result of the carried out studies quantitative characteristics were obtained which make more substantive and well-reasoned process of making decisions on the Antarctic issues both at the national and international levels.

This approach is recommended to be used as an international standard for all States-Parties of Antarctic Treaty when the Antarctic issues are considered.

\section{AN MCDM APPROACH FOR CROP PATTERN SELECTION}

Püren Veziroğlu (Turkey) $)^{1}$, Ilker Topcu (Turkey) $)^{2}$ (1. cukurova university, 2. istanbul technical university)

\section{Abstract}

Crop pattern selection is a major agricultural decision problem. As it affects the society as well as the economic and environmental conditions, to prevent failures and imbalance, a scientific approach should be utilized instead of utilizing intuitive or experimental ones which are commonly used by some farmers. Accordingly, selection of the right crops necessitates the usage of a set of evaluation criteria. This study proposes

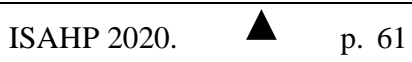


a multiple criteria decision making approach based on the AHP method to aid farmers in their stone fruit pattern selection problem. To develop the decision hierarchy, a literature survey was conducted and opinions of the experts were collected. As a case study, the owner of an agricultural company planting stone fruits in southern region of Turkey participated in our study as a decision maker and replied pairwise comparison questions. As a result, the priorities of the alternatives plum, peach, apricot, and nectarine as well as the corresponding criteria to evaluate those stone fruits were revealed. The proposed model may be used for other farmers producing the same product in that region. The approach is flexible, by updating the decision hierarchy due to characteristics of different regions or crop patterns, it may be used at other crop pattern selection problems.

\section{ANALYTIC HIERARCHY PROCESS FOR EVIDENCE-BASED POLICY MAKING}

Yoichi lida (Japan) ${ }^{1}$ (1. Suwa University of Science)

\section{Abstract}

These days the Japanese government pushes forward an approach of evidence-based policy making in their policy making and policy evaluation. As a result, it is a similar situation in the local government. The purpose of this paper is to show an actual example using the Analytic Hierarchy Process to make evidence. Most evaluators tend to ask for objective numbers as evidence, though policies, in particular in the local government, are for people who live there, and making policy is a kind of decision making by them. From the point of view, the Analytic Hierarchy Process as a group decision-making method is very helpful and useful for policy-making of the inhabitant participation, because the administrative activity should be democratic. In this paper, I showed that the committee consisting of a representative citizen of Okaya city, where the population is less than fifty thousand, evaluated the projects of their commerce revitalization plan using the Analytic Hierarchy Process. The meeting held eight times before this evaluation. Almost all of the evaluation results are concordant to that in advance of administrative officers, but the evaluation of one project was changed according to the committee's result. Consequently, we could complete "Okaya city commerce 
revitalization plan" based on the agreement.

\section{TRACK 6 - SESSION 2}

\section{8:05am}

Room: Zoom SA_T6_S2

Session Chair: Dr. Hannia Gonzalez-Urango (Spain) - Ingenio (CSIC-UPV), Universitat Politècnica de València

\section{SENSITIVITY ANALYSIS FOR THE ASSESSMENT OF ADAPTIVE} CAPACITY TO CLIMATE CHANGE: A CASE OF STUDY FROM BRAZIL

lleana Grave (Mexico) ${ }^{1}$, Luis Antonio Bojórquez-Tapia (Mexico) ${ }^{1}$, Alejandra Estrada-Barón (Mexico) ${ }^{1}$, Donald R Nelson (United States) ${ }^{4}$, Hallie Eakin (United States) $)^{5}$ (1. Laboratorio Nacional de Ciencias de la Sostenibilidad, Instituto de Ecología, UNAM, 2. University of Georgia, UGA, Department of Anthropology, 3. Arizona State University, School of Sustainability)

\section{Abstract}

While the Analytic Hierarchy Process (AHP) has been widely used to ascertain the vulnerability of households to environmental change, the sensitivity of adaptive capacity indices to uncertain appraisals and judgments of the magnitudes and weights of indicators has been largely ignored so far. In this work, we present an approach to identify the most influential indicators of household adaptive capacity. The approach entails the implementation of two sensitivity analyses: indicator removal and threshold value. The adaptive capacity indicators were selected and ranked for household surveys carried out in Brazil in 1998 and 2012.

ASSESSING THE BARRIERS TO THE DEVELOPMENT OF ELECTRIC VEHICLES IN THE URBAN TRANSPORT NETWORK OF VALENCIA

Paula Bastida-Molina (Spain) $)^{1}$, David Ribo-Perez (Spain) $)^{1}$, Tomás GómezNavarro (Spain) ${ }^{1}$, Elías Hurtado-Pérez (Spain) ${ }^{1}$ (1. Institute for Energy Engineering. Universitat Politècnica de València)

\section{Abstract}

Transport sector is responsible for around a quarter of the global $\mathrm{CO}_{2}$ 
emissions emitted to the atmosphere, and $50 \%$ in the cities. Hence, the electrification of the urban transport arises as an environmental solution to cope with the worrisome climate change. Despite the environmental suitability of electric vehicles (EVs), their integration in the urban transportation network is suffering a slow process. A wide range of barriers difficult this integration regarding different areas of the urban electric transport. These barriers present interdependence among them and can be divided in five different clusters: technical, economic, environmental, social and institutional. Many of the barriers are qualitative and/or uncertain. Therefore, the authors have used the Analytic Network Process (ANP) method in this research to rank order the barriers and, based on them, the different urban electric mobility alternatives. For that, a panel of experts with different profiles (academia, private sector, policy and users) has been formed. To illustrate its feasibility and utility, the authors designed the application of the method for a flat medium city pattern. Then, it was specifically applied to the city of Valencia. The research is still in process.

\section{PRIORITIZING THE EFFECT OF MEDIA'S INFLUENCE ON PEOPLE'S MENTAL HEALTH PERCEPTIONS}

Anastasia Marsh (United States) ${ }^{1}$, Enrique Mu (United States) ${ }^{1}$ (1. Carlow University)

\section{Abstract}

Currently most of the media's presentation of mental health and mental illness/disorder are more stigmatizing than realistic. This study will look at how media can influence the public's perception of mental illness. A survey, based on the Analytic Hierarchy Process (AHP) approach, will be used to determine if there is a type of media that has a greater influence over other types.

\section{TRACK 1 - SESSION 3}

\section{9:05am}

\section{Room: Zoom SA_T1_S3}

Session Chair: Prof. Luis Vargas (United States) - University of Pittsburgh 
ON THE SIMILARITY AMONG PRIORITY DERIVING METHODS FOR THE AHP

Pawel Kazibudzki (Poland) ${ }^{1}$ (1. Opole University of Technology)

\section{Abstract}

There are tens of priority deriving methods for the AHP although the genuine method is commonly applied i.e. the Principal Right Eigenvalue Method (REV). It is known that when decision makers (DM) are consistent with their pairwise judgments about various decision options all available methods result in the same priority vector (PV). However, when DM judgments are inconsistent, and their preferences toward alternative problem solutions are not cardinally transitive, the results usually vary. The presented work compares a few selected prioritization methods from the perspective of their ranking credibility which is evaluated with the application of a few available statistical measures i.e. Mean Average Absolute Deviation (MAAD), Mean Spearman Rank Correlation Coefficient (MSRC), and Mean Pearson Correlation Coefficient (MPCC). These measures designate the difference between priority vectors estimation quality from the perspective of the selected priority deriving methods. The examined estimates refer to the inconsistency of the pairwise comparison matrices (PCMs) which are obtained during pairwise judgment simulation process. Fundamental considerations are accompanied by Monte Carlo experiments designed for a hypothetical three levels AHP framework. The examination results show the discrepancy among examined prioritization methods from the perspective of their quality.

\section{PROPOSALS FOR THE SET OF PAIRWISE COMPARISONS}

Zsombor Szádoczki (Hungary) ${ }^{1}$, Sándor Bozóki (Hungary)1, Hailemariam Abebe Tekile (Italy) ${ }^{3}$ (1. Corvinus University of Budapest, 2. University of Trento)

\section{Abstract}

Pairwise comparison matrix is a fundamental concept of the AHP. In this paper we provide recommendations for filling in patterns of incomplete pairwise comparison matrices, when we assume that the set of 
comparisons can be chosen and it is designed completely before the decision making process, without any further prior information. Our recommendations heavily rely on the graph representation of the incomplete pairwise comparison matrices, in fact, the suggested designs are represented by (quasi-)regular graphs with minimal diameter. One major contribution of our research is a list of proposed graphs for different parameter sets, where it is important to emphasize that the diameter of the graph has not been studied in the literature as a crucial property before. On the other hand, we validate the results with the help of extended numerical simulations, which show that these filling in patterns provide smaller errors compared to other well-known designs. Both theorists and practitioners can utilize the results, provided in several formats in our research: graph, adjacency matrix, list of edges. Also, a lot of other models based on pairwise comparisons can take advantage of our findings.

\section{ANP SUPERMATRICES: LESSONS FROM HIERARCHIES}

Orrin Cooper (United States) ${ }^{1}$, William Wedley (Canada) $)^{2}$ (1. University of Memphis, 2. Simon Fraser University)

\section{Abstract}

The AHP can be referred to as a specific subset of decision models within the more general ANP. But ANP models are more complicated and perceived as difficult to understand. Viewing each column in an ANP supermatrix as a hierarchy provides clarity about how the priority vectors, clusters, and columns are combined in a supermatrix. Paying greater attention to the units of measurement and applying an AHP perspective provides answers to important questions that can significantly impact the quality of ANP decisions.

\section{TRACK 7 - SESSION 1}

9:05am

\section{Room: Zoom SA_T7_S1}

Session Chair: Prof. Xi Chen (China)-Xidian University 


\section{SELECTION OF APPROPRIATE PROJECT MANAGEMENT METHODOLOGIES FOR EMERGENCY PROJECTS USING ANALYTIC HIERARCHY PROCESS}

Chris Amponsah (Canada)1, Tamara Opokua Amponsah(United States) ${ }^{2}$ (1. Yorkville University, 2. Ross University School of Medicine)

\section{Abstract}

This paper examines appropriate project management methodologies for use in emergencies. The use of appropriate project management methodologies is contingent to the successful execution of projects in terms of organization of project time, effective utilization of resources, minimization of project risk, cost/benefit relations and development of team skills. There are several project management methodologies, but a decisive factor in applying management methodologies is that they are not all suitable for all projects. Drawing on extant literature and expert opinion from leading project management organizations involved in emergencies and disaster management, this paper assesses a number of methodologies that have been deployed in emergency situations for delivery of projects. The Analytic Hierarchy Process, noted for its flexibility, systematic approach, robustness, and reproducible evaluation, is used to assess methodologies which can be used along the project life cycle and ranked in desirable order. The findings of this study are expected to be useful in improving current project management practices as well as relevant laws and regulations in times of emergencies. The study concludes that in terms of resources, using appropriate methodology helps shorten the project team's learning curve, allows teams to focus, ensures the project is free from the distractions caused by teams going off track or budget, empowers teams to deliver results that actually impact the business bottom line and contribute to the company's strategic goals. Finally, when the methodology is adapted with focus, it is possible to lower implementation risks and improve project delivery in emergencies.

HOW YOUNG POPULATION MAKES PERSONAL FINANCE DECISIONS? EVIDENCE FROM NORTH MACEDONIA

Tamara Kaftandzieva (North Macedonia) ${ }^{1}$, Violeta Cvetkoska (North Macedonia) ${ }^{2}$ (1. PhD Student, 2. Associate Professor) 


\section{Abstract}

Psychological factors, among which the key factor being the risk attitude, combined with the socio-demographic factors, define the person's behavior and activity on the financial markets, as well as the decisionmaking regarding personal finances. The aim of this research is to analyze the decision-making process regarding financial choices of the young population in North Macedonia and to further explain young people's motives for the proposed decision and the conditions under which such decision was made. The research was conducted through an AHP-based questionnaire that was distributed to respondents younger than 35 years. According to the obtained results, the respondents value stability the most, hence their primary choice is investment in property and luxury goods. Young people are less inclined to invest, especially in the more complex financial instruments. That being the case, apart from the campaigns already created, further encouraging young people to make better and more informed decisions is necessary.

PRIORITIZED MULTI-COMMODITY FLOW MODEL AND ALGORITHM

Durga Khanal (Nepal) ${ }^{1}$, Urmila Pyakurel (Nepal) ${ }^{1}$, Tanka Dhamala (Nepal) $^{1}$ (1. Tribhuvan University)

\section{Abstract}

Prioritization is the process of deciding the relative importance or urgency of things or objects. It helps to focus on the objectives and goals in an efficient way. Prioritized flow problems are applicable for large scale disaster management problems. In this work, we introduce the priority based multi-commodity flow problem and develop a mathematical model. We also present a polynomial time algorithm to solve it.

\section{PLENARY: THREE DEVELOPMENTS OF THE ANALYTIC HIERARCHY PROCESS: CALIBRATED FUZZY AHP, AHPSORT AND GAHPO}

10:05 am

\section{Room: Zoom PLN1}

Speaker: Prof. Alessio Ishizaka (France) - NEOMA Business School

$$
\text { ISAHP } 2020 . \quad \text { p. } 68
$$


Analytic Hierarchy Process (AHP) is a popular multi-criteria decision making technique. In this talk, I will present three further developments: a) Fuzzy AHP is a hybrid method that combines Fuzzy Set Theory and AHP. It has been developed to take into account uncertainty and imprecision in the evaluations. Fuzzy Set Theory requires the definition of a membership function. At present, there are no indications of how these membership functions can be constructed. In this paper, a way to calibrate the membership functions with comparisons given by the decision-maker on alternatives with known measures is proposed. This new technique is illustrated in a study measuring the most important factors in selecting a student current account.

b) The analytic hierarchy process (AHP) is a useful and widespread method for solving choice and ranking problems. However, it is not adapted for sorting problems. Moreover, another practical limitation of AHP is that a high number of alternatives implies a large number of comparisons. This paper presents AHPSort, a new variant of AHP, used for the sorting of alternatives into predefined ordered categories. AHPSort requires far less comparisons than AHP, which facilitates decision making within large-scale problems. In this paper, a real case study for supplier selections used to illustrate our approach.

c) The third development is the Group Analytic Hierarchy Process Ordering (GAHPO) method: a new multi-criteria decision aid (MCDA) method for ordering alternatives in a group decision. The problem is separated in two hierarchies for a cost and a benefit analysis. From these two analyses, a partial ordinal ranking can be deduced, where three relations between alternatives exist: the preference, indifference, and incomparability. A complete cardinal ranking can also be deduced by dividing the score of the benefit analysis by the score of the cost analysis. GAHPO has been developed to solve a real case: a selection of new production facilities with multiple stakeholders. 


\section{TRACK 2 - SESSION 3}

11:05 am

Room: Zoom SA_T2_S3

Session Chair: Cigdem Kadaifci

GUIDANCE FOR HIGHER EDUCATION TO PROVIDE THE NECESSARY SOFT SKILLS TO MEET THE NEEDS OF INDUSTRIAL ERA 4.0 USING AHP AND FUZZY AHP

Jozef Raco (Indonesia) ${ }^{1}$, James Krejci (United States)2 ${ }^{2}$, Johanis Ohoitimur (Indonesia) $^{3}$, yulius raton (Indonesia) $)^{1}$, Jeanette Soputan (Indonesia) ${ }^{5}$, Stevanus Ngenget (Indonesia) ${ }^{1}$, Frankie Taroreh (Indonesia) ${ }^{1}$ (1. Universitas Katolik De La Salle Manado, 2. Lewis University, 3. Sekolah Tinggi Filsafat Seminari Pineleng, 4. Universitas Sam Ratulangi Manado)

\section{Abstract}

Industry 4.0 is characterized by the digitalization of systems and processes in both service and manufacturing industries and has changed the way people live. Education plays a significant role in preparing the future workforce with the necessary technological skills and competencies required by industries and institutions. Studies have shown that soft-skills improve a student's ability to learn, increase the potential for success in their life and typically provide for an increase in future economic benefits. This study aims to determine the dominant soft-skills that the University students in Manado should possess.

INCREASING EXPORT POTENTIAL OF CITRUS PRODUCTION: A CASE STUDY IN CUKUROVA REGION

Püren Veziroğlu (Turkey)1, Faruk Emeksiz (Turkey) ${ }^{1}$ (1. cukurova university)

\section{Abstract}

In agriculture it is very important to take decisions. Especially big land farmers who export their products should be more careful about this process. This study is a unique study in the agricultural economics literature. The approach combines two methods AHP and Integer Programming. Face to face survey conducted with 115 farmers in the

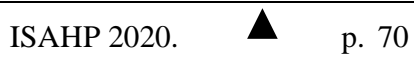


region who export Citrus fruit. According to Analytical Hierarchy Process (AHP) results, farmers' answer generally did not change in terms of market selection. Considering production target they prefer high income to low cost; quality to quantity. Moreover they prefer conventional production over organic and biological production. Certificated rootstock subsidy is the most important type of support for farmers. In addition, farmers decided that the most important support type is Marketing. Considering Integer Programming results there are 7 farmers who are satisfied if they can get input support and per decare subsidy; if they can produce targeting quality and high income; if they choose biological production; if they can get payment security; if they can sell their products to international market with cooperative. Farmers' assigned to the groups number are low it shows that there is not a consensus among farmers.

\section{PROJECT MANAGER SELECTION BY ANALYTIC HIERARCHY PROCESS}

serhat aydin (Turkey) $)^{1}$, mehmet yorukoglu (Turkey) ${ }^{1}$ (1. National Defence University Air Force Academy)

\section{Abstract}

It is critical to manage the projects that have a regenerative effect in maintaining the strategic goals of organizations. "Who will manage the project with limited time, budget and scope" and "what criteria this manager will have" affect the strategic progress of the organization. Therefore, it is a vital stage "how the project managers in an organization will be selected according to what criteria". In the study, we evaluated the different project manager by using Analytic Hierarchy Process (AHP) method. First, we determined five main criteria and 12 sub-criteria. Then, the algorithm of the AHP method is applied. Finally, alternatives are ranked according to their overall importance weight in descending order.

\section{TRACK 8 - SESSION 1}

11:05 am

Room: Zoom SA_T8_S1

ISAHP 2020. 
Session Chair: Dr. Valerio Salomon (Brazil) - Sao Paulo State University

\section{ASSESSING STAKEHOLDERS' CONFLICTS IN URBAN LOGISTICS NETWORKS THROUGH ANALYTIC HIERARCHY PROCESS}

Francesco Ciardiello (United Kingdom)1 ${ }^{1}$, Andrea Genovese (United Kingdom) ${ }^{1}$, Shucheng Luo (United Kingdom) ${ }^{1}$, Antonino Sgalambro (United Kingdom $)^{1}$ (1. Sheffield University Management School)

\section{Abstract}

Urban consolidation centre (UCC) is a typical facility that is established in many cities to deal with the issues of sustainability in urban logistics. A UCC delivery network is normally composed of various stakeholders, such as facility operator, shippers, carriers, UCC administrators, and receivers. As the attributes of these stakeholders are heterogeneous, their objectives are equally different. UCC project may result in conflicts between economic and social/environmental priorities of different stakeholders. Such conflicts might undermine the success chances of UCC projects. However, there have been insufficient discussions on the heterogeneity of the various key stakeholders' preferences and on rigorous way to capture these. This study aims to fill these gaps and promote the long-term sustainability of UCCs. Its objective is to enhance key stakeholder engagement by exploring various parties' preferences for UCC performance. In this study, a multiple-case study approach was employed, using two real-world UCCs in Sweden and two in China. A mixed-method approach (combing quantitative and qualitative methods) based on hierarchy process method (AHP) was used to identify the divergence between UCCstakeholder preferences and the reasons for such variety.

MULTI-CRITERIA VALUE ASSESSMENT FOR BUSINESS-TOBUSINESS 
Ana Beatriz Tocalinho (Brazil) ${ }^{1}$, Antonio Netto (Brazil) ${ }^{2}$, Valerio Salomon (Brazil)2 (1. Sao Paulo State University (UNESP), 2. Sao Paulo State University)

\section{Abstract}

This paper proposes a theoretical approach to apply a multi-criteria decision-making process for value assessment in business-tobusiness markets supply chain. Business-to-business are less explored in literature than business-to-consumer relations. Proposed approach adopts the Analytic Hierarchy Process due to its simplicity and flexibility in application.

STRATEGIC SUPPLIER SELECTION: THE CASE OF INTERNATIONAL FOOD TRADING COMPANY

Chuvej Chansa-ngavej (Thailand) ${ }^{1}$, Natchanok Paramaporn (Thailand) $^{1}$ (1. Regional Center for Manufacturing Systems Engineering, Chulalongkorn University)

\section{Abstract}

The objective of this research paper is to develop a strategic supplier selection system for an international food trading company using the Analytic Hierarchy Process (AHP). The products involved are canned food for worldwide export. The decision makers consist of the president and two marketing managers. The chosen decision criteria listed by weight of importance are "Export Capability" (54\%), "Pricing Policy" (28\%), "Technological Catch-up" (10\%), "Ethical Practices" (5\%), and "Environmental Management" (3\%). The sub-criteria chosen are "Number of Food Safety Certificates" (54\%), "Net Selling Price" (23\%), "Automation in Production Process" (8\%), "Payment Terms" (5\%), "Workers' Safety and Health" (4\%), "Supply Continuity" (2\%), "Packaging Varieties" (2\%), "Eradication of Child and Forced Labor" (1\%), and "Environmental Compliances" (1\%).

According to the company's existing choice of suppliers using cheap price as the selection criterion, Supplier $C$ is chosen for pineapple 
products, Supplier F for sweet corn products, and Supplier L for baby corn products. With the proposed strategic supplier selection system, the optimal suppliers for pineapple products are found to be $B$ (with a score of $33.6 \%$ ) and $D(32.8 \%)$, suppliers for sweet corn products are $\mathrm{F}(29.4 \%)$ and $\mathrm{E}(29.2 \%)$, and for baby corn products are I (32.3\%) and $\mathrm{K}(26.6 \%)$. Strategic criteria related to current business environments are found to receive substantial weights from our experts' opinion. The present work thus provides a case to substantiate the significance of strategic supplier selection and reinforces the notion that this important topic deserves a lot more attention from the business sector.

\section{TRACK 1 - SESSION 4}

\section{$12: 05 p m$}

\section{Room: Zoom SA_T1_S4}

Session Chair: José María Moreno-Jiménez (Spain)

\section{AHP AND TWO-ENVELOPE PARADOX RESOLUTION VIA NONLINEAR SCALING}

Stan Lipovetsky (United States) ${ }^{1}$ (1. independent consultant)

\section{Abstract}

Two Envelopes paradox presents a fascinating problem in probability and decision making. The player is presented with two envelopes and informed that one of them contains twice as much money as the other one. The player takes one of them without looking inside, and is then given the opportunity to change their mind and take the second envelope instead of the first one. Assuming that the $1^{\text {st }}$ envelope contains a value $A$, then the $2^{\text {nd }}$ one can have $2 A$ or $A / 2$ with equal probability, and its expected value is the mean $1.25 \mathrm{~A}$, or $25 \%$ profit from switching envelopes. It is a great result, but we could denote the amount in the $2^{\text {nd }}$ envelope as $A$ and repeat the derivation outcome $1.25 \mathrm{~A}$ already in $1^{\text {st }}$ 
envelope, so each of them is worth more than the other one. So, to switch or not to switch? - That is the question. As shown in this article, the ideas borrowed from the Analytic Hierarchy Process can help in resolving this paradox by transforming the ratio scale into the additive or logarithmic scales which correspond to application of the multiplicative utility function.

INFLUENCE ANALYSIS IN ANP MODELS - ADVANTAGES AND PITFALLS

Elena Rokou (United States) ${ }^{1}$, William Adams (United States) ${ }^{2}$ (1. CDF, 2. Decision Lens)

\section{Abstract}

After an ANP model is created and yields synthesized values for the alterna- tives we would like to understand how the structure of the model effects the results of the model. In traditional AHP tree models we can use sensitivity to increase or decrease the importance of a given node, and see how the alterna- tives change. With the advent of ANP row sensitivity we can perform a similar analysis on ANP models. However, this only yields a weak qualitative analysis of the situation (that is we can only roughly tell that this node appears to move alternatives more or less than the others). A more desirable analysis would be a single non-negative numerical value that describes the quantity of influence for each node.

\section{BUILDING AN EVALUATION "COMMON GROUND" FOR RESEARCH ON AHP REFINEMENTS}

robin rivest (Canada) ${ }^{1}$ (1. HEC Montreal)

Abstract

From its inception in the late 70's/early 80's, the Analytic Hierarchy Process (AHP) has attracted the interest of multiple criteria decision aid (MCDA) scholars and practitioners all around the world. Thousands of reviewed papers on the AHP have been published 
through the years, and its reach is extensive, as one might consider that if you put "analytic hierarchy process" in Google Scholar, you get over 1.5 million entries.

Most AHP research papers report on specific applications of the method to various business decision contexts. However, there is a significant portion of these publications that explore the inner workings or theoretical aspects of the method, proposing improvements or bringing attention to potential drawbacks. A large proportion of those papers address one of the three following topics: choosing a numerical scale, reducing the number of necessary comparisons, or deriving the priority vector.

When one considers this overall body of work, the disconcerting finding is that none (or too few of them) share a common basis to illustrate or highlight the performance of their suggestion. There is a compelling need for an evaluation framework that would enable informative comparisons between the various approaches. This lack of a validation "common ground" is the subject of my master's thesis [Rivest, 2019] which introduces several foundational elements with the intent to launch a dialog with both scholars and practitioners about providing the AHP community with a shared evaluation framework for these areas of research and more.

\section{TRACK 11 - SESSION 1}

\section{2:05pm}

\section{Room: Zoom SA_T11_S1}

Session Chair: Dr. Orrin Cooper (United States) - University of Memphis

INVESTIGATION OF CATALYST PROJECTS AND URBAN DESIGN QUALITIES IN SIX CENTRAL STREETS OF HAMEDAN

sajjad zolfigol (Iran, Islamic Republic of) $)^{1}$, mehran Alalhesabi (Iran, Islamic Republic of) ${ }^{2}$, seyed majid mofidi shemirani (Iran, Islamic 
Republic of $)^{3}$ (1. Ph.D. student in Urbanism, School of Architecture and Environmental Design, Iran University of Science and Technology., 2. Associate professor of Urbanism, School of Architecture and Urban Development, Iran University of Science and Technology., 3. Assistant Professor in urban design, School of Architecture and Urban Development, Iran University of Science and Technology.)

\section{Abstract}

Streets are like a vein in the body and play an important role in whole cities. These crucial elements are so essential in each cities structure. The primary roots of the system can quickly figure out by the distribution of city streets. So central streets are more critical than the peripheral ones because more users refer to them. Hamedan is a mountainous city in the west of Iran, which is shape by circles form. This unique structure is exceptional in Iran and is based on the main square and its six streets. This paper tries to figure out the differences between this street, catalyst intervention, and car-driven streets. Also, comparing these two types of streets and their results can help urban management and city responsible. Catalyst projects are some intervene that seek to inject new spirit in target areas. These actions are trying to respond to further people's needs based on the context's general identity. The research methodology is quantitative based on ANP techniques to specify these six streets' priorities and interpret differences between catalysts projects and cars-driven streets. So the results show that two streets among six central streets are more acceptable in users' mindsets. Bu Ali st and Ekbatan st have high normalized points than other streets. Besides, users can easily walk all the parts of these two streets, perform window shopping, sit wherever they want, and do all kinds of group and individual activities. These consequences have more overlapping with two streets that have been intervened by catalyst actions, and their roles transformed into walk-able instead of car-driven streets. 


\section{CLASSIFICATION RELIABILITY FOR GIS-MCDA: AHP AND SENSITIVITY ANALYSIS}

Ileana Grave (Mexico) ${ }^{1}$, Victor Hernández-Díaz (Mexico $)^{1}$, Fidel Serrano-Candela (Mexico) ${ }^{1}$, Tatiana Merino (Mexico) ${ }^{4}$, Yosune Miquelajauregui (Mexico) ${ }^{1}$, Luis Antonio Bojórquez-Tapia (Mexico) ${ }^{1}$ (1. Laboratorio Nacional de Ciencias de la Sostenibilidad, Instituto de Ecología, UNAM, 2. Posgrado en Ciencias de la Sostenibilidad, UNAM)

\section{Abstract}

One major challenge in Geographical Information SystemsMulticriteria Decision Analysis (GIS-MCDA) is the classification selection to visualize a meaningful spatial pattern. This work proposes a systematic method to (1) select a classification scheme with spatial meaning and to (2) quantify the accuracy of the most sensitive layers, based on a sensitivity analysis. The method is applied to one important aspect of vulnerability assessment (exposure) of the coastal of Yucatán, Mexico where, given a model obtained with the Analytic Hierarchy Process (AHP), the visualizations with meaningful spatial patterns were selected and the most sensitive attributes were identified.

\section{A MULTI CRITERIA ANALYSIS TO EVALUATE FUNCTIONING OF PHOTOVOLTAIC POWER PLANTS IN PAKISTAN}

Muhammad Asad (Italy) ${ }^{1}$, Antonella Petrillo (Italy) ${ }^{2}$, Fabio De Felice (Italy) ${ }^{3}$ (1. Department of Engineering - University of Naples "Parthenope", Italy, 2. Department of Engineering - University of Naples "Parthenope", 3. Cassino and Southern Lazio, Italy)

\section{Abstract}

Since 2005 Pakistan has been entrenched in an energy crisis which has not only crippled the economy but has also resulted in huge problems for the masses. Presently the energy shortfall is at $6000 \mathrm{MW}$ with an average load shedding of 6 to 8 hours in urban areas of the country. Apart from that $40 \%$ of the rural areas are not 
connected to the national grid and have no access to electricity. Pakistan being close to the equator receives abundant sunlight and therefore has a huge solar potential. The irradiation in majority of the cities in Pakistan is close to 4.5 kilo watt hour per day which is very high and can be used to produce electricity through solar technologies such photovoltaic or solar thermal. The solar potential in Pakistan is enormous and can play a key role in minimizing the energy shortfall in Pakistan. In this context, promoting the use of photovoltaic technologies could represent an opportunity for the country. Thus, the aim of the present study is to investigate, through an AHP model, effective factors for the correct functioning of the plant to increase its potential.

\section{POSTER SESSION 2}

\section{1:05pm}

\section{Room: Zoom POS2}

Session Chair: Prof. Antonella Petrillo (Italy) - Department of Engineering - University of Naples "Parthenope"

\section{TOTAL DECISION SOFTWARE}

Daniel Villa (Chile) ${ }^{1}$, Claudio Garuti $\left(\right.$ Chile) ${ }^{1}$ (1. Fulcrum Engeneering)

\section{Abstract}

Total Decision is a software that use the Analytic Hierarchy Process (AHP) as an engine to find solutions at all levels and align them with the organization's objectives. Is developed in Chile by VILENIO with the methodogical supervision of FULCRUM Engineering.

Total Decision has been used by the Ministry of Education in Chile, Ministry of Social Development, in different Universities in Chile and by students around the world.

Currently, through feedback by many users, VILENIO is developing Total Decision 2.0 which will facilitate to get data from different experts online and show the compatibility degree between them in order to reach better consensus. 
Visit https://www.vilenio.com - (web page in spanish) Download free: https://www.vilenio.com/td_download.html (instructions, user manual and requeriments in spanish and english) For more info please contact us: info@vilenio.com

\section{AHP FOR EVERYBODY: INNOVATION THROUGH MOBILE APPLICATION FOR PERSONAL DECISIONS}

Sovit Poudel (Nepal) ${ }^{1}$, Shashi Bhattarai (Nepal) ${ }^{2}$ (1. Truenary Solutions, 2. Knowledge Holding International)

\section{Abstract}

The paper describes how we reached to develop a working prototype and launched an Analytic Hierarchy Process (AHP) based mobile application for day to day use. Growing internet enabled information reach to individuals via smartphone has created potential for individual decision support systems. Automation and productivity enhancement to people is converging in smartphones. There exists software to process multiple criteria decisions for enterprise level application. However, it is observed that there is not yet a simple user friendly, theory-based decision support application with visualization for individuals. The idea of potential of AHP based personal decision support system was identified ten years back; however, a product was realized recently. The product makes a theory based scientific multi criteria decision support tool available for common people to easily use by automating the process through an interactive interface. Up until now, the experience of such software was either geared towards a enterprise, or someone who understood the theoretical backing. The mobile application is perceived to be the first of its kind with features of dynamic sensitivity analysis. Change in ranking of alternatives can be instantly seen while changing weight of criteria, the feature is called decision visualization. Considering continuous improvement with the user feedback, a mobile application called DecisionMentor is released and available in application stores for common people's use.

SCHOOL AND ACADEMIC PERFORMANCE: SOME EVIDENCE FROM ITALY

Antonella Ferraro (Italy) ${ }^{1}$, Paola Mancini (Italy) ${ }^{1}$, Gabriella Marcarelli

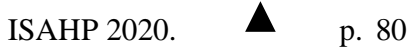


(Italy) $)^{1}$ (1. University of Sannio)

\section{Abstract}

Our aim is to investigate and compare the performance of Italian public High Schools in order to provide citizen more complete information about different types of high school and give parents a tool to support their children in the school choice. We consider three outputs provided by average students' school and academic performance, and school characteristics. Our sample includes 263 high schools (HS) in all Italian Regions, grouped into 6 different types of schools and 3 geographic areas. Our results show that: there are significant differences between HSs according to school and academic performance both within and between geographic areas; the ranking does not vary but the intensity of preferences may be different according to the macro-area and/or the output considered. In this paper, we use the AHP to derive a final ranking among different types of schools, by assigning specific weights to outputs, and then we perform a sensitivity analysis to understand the differences among geographic areas. Considering their preferences, parents could attribute personal weights to each indicator in order to derive a ranking of schools.

COMPARISON OF THE APPLICATION OF PRODUCTION MANAGEMENT TOOLS AND TOPSIS-AHP METHODS: BEARING MAINTENANCE PROCESS

José Oliveira (Brazil) (1. Paulista State University "Júlio de Mesquita Filho" - UNESP)

\section{Abstract}

There is no doubt that in the industrial environment decisions become more and more complex tasks for managers. Decision analysis methodologies also make up the arsenal of techniques and tools that can be used for better answers, combined with other classic quality and problem solving tools. Decision makers should not make them instinctive, based on feelings and hunches, but using analytical and quantitative tools. In this context, methods such as Technique for Order Preference by Similarity to Ideal Solution (TOPSIS) and Analytic Hierarchy Process (AHP) become useful tools for decision making. This article presents a case study of a large bearing maintenance process used in the steel, 
mining and sugar-energy industries, where from the application of production management tools; which at a certain level; are purely exploratory and poorly structured approaches to decision making; and of Decision Making Aid Methods (MCDM) allow to obtain similar responses in the prioritization of actions to eliminate or mitigate the effects, from the treatment of possible causes. 


\title{
SUNDAY DECEMBER 6
}

\section{TRACK 2 - SESSION 4}

\section{8:05am}

\section{Room: Zoom SU_T2_S4}

Session Chair: Cigdem Kadaifci

\section{APPLYING THE ANALYTIC HIERARCHY PROCESS IN FACULTY SEARCH}

Carlo Smith (United States) ${ }^{1}$, Ozden Bayazit (United States) ${ }^{1}$ (1. Central Washington University)

\begin{abstract}
In this paper, we describe our application of the AHP to fill a tenure-track position. Criteria identified as important to the decision included "Degree, teaching, student engagement, research, service, experience, and diversity." Several sub-criteria were associated with each main criteria. Not surprisingly, though main selection criteria are common across higher education institutions, our institution mainly serves an undergraduate population and the perceptions and judgments of search committee members reflected the higher relative importance of criteria associated with teaching and student development. In the case presented, three finalists for an assistant professor position passed the initial screening and phone interviews and were invited for campus visits. Following the visits, we built our AHP model that included the aforementioned primary criteria as well as associated sub-criteria. After constructing the hierarchy, each search committee member completed pairwise comparisons of the criteria. The results of the model helped prioritize the criteria and recommend a candidate for follow up.
\end{abstract}

ANALYSIS OF THE TECHNICAL AND ECONOMIC FEASIBILITY OF USING ELECTRIC PROPULSION IN BRAZILIAN NAVY PASSENGER TRANSPORT VESSELS: AN APPROACH OF AHP METHOD

SÉRGIO MITIHIRO DO NASCIMENTO MAÊDA (Brazil) ${ }^{1}$, Igor Pinheiro de

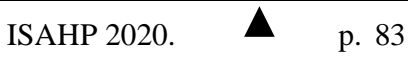


Araújo Costa (Brazil) ${ }^{1}$, Luiz Frederico Horácio de Souza de Barros Teixeira $(\text { Brazil) })^{3}$, Carlos Francisco Simões Gomes (Brazil) $)^{1}$, Marcos dos Santos (Brazil) $)^{5}$, Marcos Alexandre Pinto de Castro Junior (Brazil) ${ }^{6}$, Arthur Pinheiro de Araújo Costa (Brazil)7, José Victor de Pina Corriça (Brazil)7 (1. Universidade Federal Fluminense (UFF), 2. Centro de Análises de Sistemas Navais (CASNAV), 3. Instituto Militar de Engenharia (IME), 4. Pontifícia Universidade Católica (PUC), 5. Marinha do Brasil)

\section{Abstract}

The access of students, civil and military servants from the pier of the 1st Naval District to Hoe island (located in Guanabara Bay, Rio de Janeiro/Brazil) occurs through vessels that carry out a daily travel routine, generating considerable fuel consumption. The purpose of this work is to analyze the technical and economic feasibility of implementing electric propulsion by lithium-ion batteries in new vessels, to replace the current ones, which use the conventional diesel system. For this purpose, technical and operational data were collected from these vessels, commercial proposals were requested from companies in the sector, and the Analytic Hierarchy Process (AHP) method was used to assist in the assessment of the main criteria involved. The study verified the feasibility of the project and may serve as a basis in order to promote this technology on other vessels in the various districts of the Brazilian Navy.

STRATEGIC PRIORITIES OF THE RELIGIOUS INSTITUTION USING COMBINATION OF SWOT AND FUZZY-AHP. CASE STUDY OF THE CONGREGATION OF MISSIONARIES OF THE SACRED HEART

Jozef Raco (Indonesia) ${ }^{1}$, Johanis Ohoitimur (Indonesia) ${ }^{2}$, James Krejci (United States) ${ }^{3}$, yulius raton (Indonesia) ${ }^{1}$, Anselmus Jamlean (Indonesia) $^{2}$, Ignasius Welerubun (Indonesia) ${ }^{2}$, Rafael Tanod (Indonesia) ${ }^{1}$ (1. Universitas Katolik De La Salle Manado, 2. Sekolah Tinggi Filsafat Seminari Pineleng, 3. Lewis University)

\section{Abstract}

Strategic priorities are quite commonly implemented by both profit and non-profit institutions but quite rarely employed by religious congregations. The congregation of the Missionaries of the Sacred Heart (MSC), an institution in Catholic Church, has undertaken an empirical study, using a combination of SWOT and fuzzy-Analitic Hierarchy Process 
(AHP) methodologies.

\section{TRACKS 6 AND 7}

8:05am

\section{Room: Zoom SU_T6_T7}

Session Chair: Müjgan Sağır (Turkey) - Eskisehir Osmangazi University

\section{SELECTION OF MEDICAL WASTE TREATMENT CENTERS USING ANP}

Xin Li (China) $)^{1}$, Xi Chen (China) $)^{1}$, Mujgan Sagir (Turkey) $)^{3}$ (1. Xidian University, 2. Eskisehir Osmangazi University

\section{Abstract}

The outbreak of the COVID-19 continues to date, which poses a great threat to social security and stability. In the short term, there is a large increase in the infectious medical waste (IMW), the pressure of medical waste treatment centers (MWTCs) is greatly enlarged and the probability of contact infection is significantly augmented. If IMW is improperly disposed of, it may accelerate the spread of the virus and pose a risk to the target population. Choosing the best disposal site for IMW is a challenging decision-making issue. Therefore, this paper proposes an evaluation model based on analysis network process (ANP), and establishes a universal risk assessment method system for MWTCs, aiming to determine the optimal treatment location of IMW, so as to effectively deal with a large amount of IMW in a very short time and reduce the risk of infection. Finally, the feasibility and effectiveness of the method are illustrated with an example of Wuhan, Hubei province, China during COVID-19. The conclusion of this study can provide a reference for the selection of MWTCs under infectious diseases.

MODEL TO DETERMINE THE INVESTMENT PRIORITY FOR TELECONTROLLED FACILITIES IN SANITARY INDUSTRY IN CHILE TO ADAPT TO CLIMATE CHANGE

Claudio Macuada (Chile) ${ }^{1}$, Astrid Oddershede (Chile) ${ }^{1}$, Luis Quezada (Chile) $^{1}$, Pedro Palominos (Chile) $)^{1}$ (1. University of Santiago of Chile) 


\section{Abstract}

This study proposes a methodology to support decision making when determining the order of investment of telecontrolled facilities in the health industry, contemplating the impacts of climate change. The sanitary industry has been constantly concern in providing greater resilience to the supply of drinking water in face of the effects related to climate change by improving its processes; augmenting the coverage, continuity and quality of drinking water and treatment of sewage water in all Chilean cities. This has had a very favorable impact on the population health and has allowed for a great development of tourism and the agro-food industry; all this, with low rates compared to other countries. The water industry is aware that it is necessary to keep up the speed of investments to maintain service levels and to deal in a timely and effective manner with events that involve customers, due to environment situations, climate change and also the operational and human contingencies of companies in the sector. In this sense, the water industry is adopting new technologies for its processes, with the purpose of making them a factor of service improvement. Currently, the Chilean Sanitary Industry is concerned about the degree of automation and infrastructure requirements, since they are the main critical factors for planning future investments. This document emphasizes the development of a decision model applying the Analytical Hierarchy Process (AHP), to define the order of medium term investments for remote controlled facilities.

\section{AHP- BASED SOCIAL VULNERABILITY INDEX FOR SMALL FISHERIES IN YUCATAN, MEXICO}

Tatiana Merino (Mexico) ${ }^{1}$, lleana Grave (Mexico) ${ }^{2}$, Luis Antonio Bojórquez-Tapia (Mexico) ${ }^{2}$ (1. Posgrado en Ciencias de la Sostenibilidad, UNAM, 2. Laboratorio Nacional de Ciencias de la Sostenibilidad, Instituto de Ecología, UNAM)

\section{Abstract}

We present here an implementation of the AHP for the development of a Social Vulnerability Index (SVI). Our approach addresses the inherent subjectivity of experts' judgements regarding the required pairwise comparisons. Using sensitivity analysis based on local partial derivatives, 
we identify the expert with the most sensitive pairwise comparison. In this way, it is possible to contrast the background and experience of the experts and the AHP's output. The results enable an understanding of individual expert's effect on the analysis that can be used to generate the best possible SVI. We illustrate the approach through the case study of household vulnerability of small fishing communities in Yucatan, Mexico.

\section{TRACK 1 - SESSION 5}

9:05am

Room: Zoom SU_T1_S5

Session Chair: Prof. Luis Vargas (United States) - University of Pittsburgh

WEIGHTED AVERAGE VS TOPSIS: A COMPARISON OF AGGREGATION METHODOLOGIES FOR AHP

Francesco Ciardiello (United Kingdom)1, Andrea Genovese (United Kingdom $)^{1}$ (1. Sheffield Management school)

\section{Abstract}

Starting from the observation of an ever-increasing number of publications in the field of supplier selection problems utilising multicriteria decision-making methodologies, this paper aims at providing a critical comparison of some of the most utilised approaches in this context.

According to Bruno et al. (2012), Analytical Hierarchy Process (AHP) (and its variant, Analytical Network Process, ANP) (Saaty, 1980) is, by far, the most popular methodology for dealing with the supplier selection problem, that represents one of the quintessential multi-criteria decision making problems. The main strength of AHP lies in the possibility of combining it with a large variety of other methodologies, for obtaining flexible, customised and tailored solution approaches. This has led to a plethora of approaches being available in the literature; however, often it is not clear what are the advantages and the disadvantages of specific techniques, both in terms of performances related to both computational results and decision support. The result is a strikingly growing body of 
literature, whose practical contribution, apart from technical aspects (related to the development of new methodologies), may be questionable

Considering this evidence, the goal of this paper is to provide a structured comparison of two of the most popular methodologies employed in combination with the Analytic Hierarchic Process (AHP) in solving supplier selection and similar multi-criteria decision making problems: the Weighted Average and TOPSIS (Technique for Order of Preference by Similarity to Ideal Solution) (Lima et al., 2014). Both these methods, indeed, are often utilised as aggregation modes for multi-criteria decision-making frameworks, in which AHP (or ANP) is utilised in order to derive weights of involved criteria.

EXTENSION OF THE AHP METHOD TO GROUP DECISION-MAKING FOR DETERMINING THE BEST CARE CENTER OF SEVERE CASES OF COVID-19 IN OUAGADOUGOU/BURKINA FASO: THE CASE OF THREE DECISION MAKERS.

Zoïnabo Savadogo (Burkina Faso) ${ }^{1}$, Frédéric NIKIEMA (Burkina Faso) ${ }^{2}$, Somdouda SAWADOGO (Burkina Faso) ${ }^{3}$, Blaise SOME (Burkina Faso) ${ }^{2}$ (1. university of Joseph Ki-Zerbo, 2. Université Joseph KI-ZERBO, 3. Institut Des Sciences (IDS)

\section{Abstract}

The world has been rocked by the covid 19 pandemic from Marchuntil today. Each country is trying somehow to find a solution. Inthe literature on decision support, it seems that a decision made by asingle individual reflects little reality, hence the importance of groupdecision support.There are methods of solving group decision problems, but usingsome of them leads to a lot of calculations and others give controver-sial results. It is in this context that we extended the AHP methodto group decision-making to determine the best health center for themanagement of severe cases of covid-19 in the city of Ouagadougou/burkina faso.

TRANSMISSION LINE ROUTING USING GIS TOOLS OF SPATIAL SCIENCES

Nawa Raj Chapagain (Nepal)1, Subrat Subedi (Nepal)1, Neha Joshi 
(Nepal) ${ }^{1}$, Bibek Rai (Nepal) ${ }^{1}$, Binay Paudyal (Nepal)1, Ashish Regmi (Nepal)1, Rajiv Bishwokarma (Nepal) ${ }^{1}$, Saroj Ghimire (Nepal) ${ }^{1}$, Komal Atreya $(\text { Nepal) })^{9}$ (1. NEA Engineering Company Limited, 2. Nepal Electricity Authority)

\section{Abstract}

The conventional method of Transmission Line Routing is based on expert judgment, making it sub-optimal, subjective and biased. This paper introduces, elaborates and implements a new method of Transmission Line Routing based on Geographic Information System, which not only eliminates the biasedness during routing but also helps to maintain the balance between conservation and development. Transmission Line Routing using GIS tools of spatial sciences involves identification of factors affecting transmission line route such as land-use data, settlements, roads, slope etc. and preparation of several parameters sets by specifying different weight/cost index values to each of these factors and their subcategories, based on different priority for different factors. Modified Dijkstra $\left(A^{*}\right)$ algorithm implemented in python computer program was used to calculate the least-cost path from the start point to an endpoint on the combined weighted raster for each of the parameter sets. The least-cost path represented the transmission line route alignment in this case. Lastly, a case study based on the implementation of the GIS concept of routing a $400 \mathrm{kV}$ Transmission Line of over $70 \mathrm{~km}$ has been presented. The study shows that GIS-based transmission line routing is a flexible and effective method of tracing the routes.

\section{TRACK 5 - SESSION 2}

9:05am

\section{Room: Zoom SU_T5_S2}

Session Chair: Mario Sandoval

EVALUATING THE EFFECT OF ORGANIZATIONAL MINDFULNESS IN HEALTH ORGANIZATIONS IN COLOMBIA

Yuli Leon (Colombia) ${ }^{1}$, Enrique Mu (United States) ${ }^{2}$ (1. University of 
Rosario, 2. Carlow University)

\section{Abstract}

A study of the state of organizational mindfulness in the Colombian health sector has been carried out. Using an evaluation framework based on the analytical hierarchical process (AHP) and surveys of 117 leaders of the sector, the situation of the sector has been analyzed with respect to each of the dimensions of organizational mindfulness: Reluctance to simplify interpretations, preoccupation for failures, sensitivity to operations and commitment to resilience / respect for knowledge (RSI, $\mathrm{PF}, \mathrm{SO}$ and $\mathrm{CRRC}$ ). The results show that there is a significant positive effect of at least 3 of these dimensions on the rationality of health decisions and that it is possible and useful to assess the extent of organizational mindfulness through the AHP-based framework proposed by Mu and Butler (2009).

\section{SELECTION OF BEST HOSPITAL FOR KIDNEY TRANSPLANTATION USING AHP: A CASE FOR TURKEY}

Fatma Kutlu Gündoğdu (Turkey) ${ }^{1}$, Ali Karasan (Turkey) ${ }^{2}$ (1. National Defence University, 2. Yildiz Technical University)

\section{Abstract}

The assessment of service quality in a hospital for organ transplantation has been mainly ignored by health care suppliers, although it has vital importance for human life. In this study, service quality parameters are determined in the light of four SERVQUAL dimensions, including responsiveness, reliability, tangibles, and empathy, and a survey has been conducted. Twenty-one patients who are suffering from kidney failure and also their relatives have attended this survey. The analytic hierarchy process (AHP) is constructed to select the best hospital in Istanbul for kidney transplantation based on these service quality parameters, and results are discussed.

FUZZY AHP MODEL TO SUPPLIER PERFORMANCE EVALUATION IN PUBLIC INSTITUTIONS

Juliana Leyton (Colombia) ${ }^{1}$, Juan Osorio $\left(\right.$ Colombia) ${ }^{1}$ (1. Universidad del 
Valle)

\section{Abstract}

The problems that arise in the selection of suppliers do not end when the correct supplier is found and a contract is established. The problems can persist throughout the customer-supplier relationship. Working to increase knowledge about each supplier is the most effective way to minimize potential complications related to the purchasing function and its effects on the supply flow. The objective of this document is to present an integrated model for the objective evaluation of suppliers in a Higher Education Institution of the Public Sector, which, in turn, is subject to a series of regulations, legal provisions and control entities. In this sense, a methodology of Fuzzy Analytical Hierarchy Process (Fuzzy AHP) is proposed, which uses fuzzy preference relationships to incorporate the ambiguities and uncertainties that usually exist in human judgment. Additionally, sensitivity analysis is performed to demonstrate the credibility of the model.

\section{PLENARY: AHP/ANP: ISSUES AND INSIGHTS FOR THE FUTURE}

\section{0:05am}

\section{Room: Zoom PLN2}

Presdenter: Dr. William Wedley (Canada) - Simon Fraser University

AHP/ANP provide a comprehensive procedure for capturing the intensities of different properties on a ratio scale and then combining multiple such scales into a meaningful multi-criteria decision. The ratio feature, ease of use, and flexibility to measure many phenomena has allowed AHP/ANP to become the dominant MCDM procedure. Insights from the evolution of the techniques will be used to highlight issues that may be useful for the future. The nature of ratio intensities will be emphasized. 


\section{TRACK 3 - SESSION 2}

\section{1:05am}

\section{Room: Zoom SU_T3_S2}

Session Chair: Azilah Anis (Malaysia)

DISPATCH PRIORITIZATION IN AN AGRICULTURAL FERTILIZER COMPANY USING AHP AND TOPSIS

J Jorge Rojas (Colombia) ${ }^{1}$, Juan Osorio (Colombia) ${ }^{1}$ (1. Universidad del Valle)

\section{Abstract}

Inside of logistics operations, the inventory as a distribution resource does a very important role in the generation of value for companies. The decisions made in each dispatch to a distribution center could affect the level of service, the finances (working capital), the costs associated with movements of items between distribution centers, slow-moving inventory, and lost sales. This work shows the planning of dispatch from an agricultural fertilizer producing plant to its distribution centers around the country (Colombia) using AHP and TOPSIS from six logistics indicators, one sales indicator, and one financial indicator.

SUPPLIER SELECTION USING AHP AND TOPSIS IN FOOD COMPANIES CONSIDERING OPERATIONAL RISK

Jenny Hurtado (Colombia) ${ }^{1}$, Katherine Hurtado (Colombia) ${ }^{1}$, Juan Osorio (Colombia) ${ }^{1}$, Carolina Lima (Colombia) ${ }^{1}$ (1. Universidad del Valle)

\section{Abstract}

Supplier selection is one of the essential activities in the current supply chain management. Due to the supplier has a fundamental role in the chain, we notice the importance of a suitable selection process. It is clear that provider selection is a multi-criteria decision-making problem, and therefore appropriate tools are required to perform this process. Additionally, suppliers tend to influence the supply chain risks, so the requirement to include potential risks in the selection criteria of these suppliers becomes apparent. This work proposes using the Analytic Hierarchy Process (AHP) combining with Technique for Order of 
Preference by Similarity to Ideal Solution (TOPSIS) for supplier selection of a Colombian company in the food sector. In addition to the traditional criteria considered in a supplier selection process, this proposal includes some operational risks among these criteria. We use AHP to define the weight of the criteria and TOPSIS to select the supplier.

THE ANALYTIC HIERARCHY PROCESS: APPLICATION TO THE SELECTION OF THE BEST E-WALLET IN KLANG VALLEY, MALAYSIA

Rajan Amaloo (Malaysia) ${ }^{1}$ (1. Department of Business Administration, International Islamic University Malaysia)

\section{Abstract}

Parties conducting electronic business have usually never seen each other face-to-face, nor do they exchange currency or hard copies of documents hand-to-hand. When companies enter electronic commerce, choosing an electronic payment (e-wallet) system that will work well with the way they run their business, which is both popular and safe, is a major concern. In this paper, after examining different e-wallet systems in Klang Vallet, Malaysia, we identify assessment criteria based on previous researches and interview with experts. Then, using analytic hierarchy process (AHP) we prioritize e-wallet systems in Klang Vallet, Malaysia based on experts opinions. Results show that Samsung Pay is the most preferred e-wallet system, followed by Lazada Wallet and Boost. The findings of this research are intended to be useful for both academic researchers and companies planning to adopt or to improve an electronic payment system.

\section{AHP APPLICATIONS}

\section{1:05am}

\section{Room: Zoom SUN_APPS}

Session Chair: Rozann Saaty (United States) - Creative Decisions Foundation 
A MCDM MODEL FOR MEASURING THE PREPAREDNESS LEVEL OF SALES DEPARTMENTS IN COVID-19 AND FUTURE PANDEMICS: ELECTRICAL APPLIANCE SECTOR

Miguel Ortíz-Barrios (Colombia)1, Iván-Darío Gómez-Villar (Colombia)², Arlen Borrego-Areyanes (Colombia) ${ }^{3}$, Antonella Petrillo (Italy) ${ }^{4}$ (1. Department of Productivity and Innovation, Universidad de la Costa CUC, Barranquilla, 2. Department of Business Administration, Universidad de la Costa CUC, Barranquilla, 3. Department of Business Administration, Universidad de la Costa CUC, Barranquilla, 4. Department of Engineering - University of Naples "Parthenope")

\section{Abstract}

A multi-criteria decision making model for measuring the preparedness level of sales departments when facing COVID-19 waves and future pandemics is proposed. The model is comprised of 8 criteria, 29 subcriteria and 7 alternatives. AHP is used for calculating the criteria and subcriteria weights. While, TOPSIS is used for calculating the preparedness level, ranking the companies and identifying the weaknesses that should he addressed for increasing their effectiveness in the current market scenario. This application is completely novel in the literature and has been applied in the wild with remarkable companies in Colombia. A case study in electrical appliance sector is presented.

\section{DETERMINING CRITERIA AND SUB-CRITERIA WEIGHTS FOR THE SELECTION OF REGIONAL CENTERS OF COMPETENCE IN CROATIA}

Bojan Zugec (Croatia) ${ }^{1}$, Blazenka Divjak (Croatia) ${ }^{2}$, Nina Begicevic Redjep (Croatia) $^{2}$ (1. Universty of Zagreb, Faculty of organization and informatics, 2. University of Zagreb, Faculty of organization and informatics)

\section{Abstract}

In this paper, a process of determining the criteria and sub-criteria weights for the selection of Regional Centers of Competence (RCC) in sector of vocational education is described. In 2018, the Croatian Ministry of Science and Education was responsible for creating a document comprising all parameters and criteria for this selection, named The Network of Regional Centers of Competence, and requested assistance in determining the criteria and sub-criteria weights to be incorporated 
within. The criteria were predefined pursuant to the national Vocational Education and Training Act and, to determine the weights, the AHP decision making group of the members of the Council for Vocational Education were engaged. There were 10 criteria with the total of 64 subcriteria in this process, and to make it more efficient, pairwise comparison was made for the criteria and an inverse ranking method for the sub-criteria weights. Because of the enhanced number of pairwise comparisons, it was quite challenging for some decision makers to stay consistent. Therefore, the inconsistency coefficient was used to calculate the decision makers' weights, to incorporate the reliability of their comparisons in the overall process.

\section{AHP FOR LAND VALUATION IN LAND ACQUISITION FOR INFRASTRUCTURE DEVELOPMENT}

\section{Subash Ghimire (Nepal) ${ }^{1}$ (1. Kathmandu University)}

\section{Abstract}

Investment in infrastructure development for public purpose is very important for the development of any country. This investment often needs a huge quantity of land. Inadequacy of compensation amount i.e low valuation is one of the main causes for opposition and delays by affected land owners in land acquisition. GIS technology is not applied in land valuation for land acquisition in infrastructure development. Therefore, GIS with Analytic Hierarchy Process is an effective tool for dealing with complex decision by setting priorities and makes the best decision. In this context, the main objective of this study is to develop the land valuation model by using GIS and AHP for infrastructure development. The quantitative and qualitative research methodologies are adopted for this study. The pairwise comparisons of different criteria by its importance carried out from the response of different stakeholders and calculation of Eigenvector in Fast Track Road Project, Chattiwan VDC. The weightage overlay in GIS is carried out with road class, built up class, slope class, forest class, soil type class and river class by using weighted overlay tool. The joined weighted Parcel shapefile is added with fields, Government value (GV), Market value (MV), Raster Weight and Model Price. Then, the joined weighted parcel shapefile is visualized based on Model Price. The land value is determined with spatial analysis and 
Analytical Hierarchy Process (AHP). A numerical weight or priority is derived for each element of the hierarchy. The decision makers systematically evaluates its various elements by comparing them to each other two at a time.

\section{TRACK 4 - SESSION 1}

\section{2:05pm}

\section{Room: Zoom SU_T4_S1}

Track Chair: Prof. Alessio Ishizaka (France) - NEOMA Business School

APPLICATION OF THE AHP-TOPSIS-2N HYBRID METHOD FOR SELECTION OF AN ATTACK HELICOPTER TO BE ACQUIRED BY THE BRAZILIAN NAVY

Igor Pinheiro de Araújo Costa (Brazil) $)^{1}$, Marcos Alexandre Pinto de Castro Junior (Brazil)2), SÉRGIO MITIHIRO DO NASCIMENTO MAÊDA (Brazil)'1, Luiz Paulo Fávero (Brazil)4, Arthur Pinheiro de Araújo Costa (Brazil) ${ }^{5}$, José Victor de Pina Corriça (Brazil) $)^{5}$, Carlos Francisco Simões Gomes (Brazil) ${ }^{1}$, Marcos dos Santos (Brazil) ${ }^{8}$ (1. Universidade Federal Fluminense (UFF), 2. Pontifícia Universidade Católica (PUC), 3. Universidade de São Paulo (USP), 4. Marinha do Brasil, 5. Instituto Militar de Engenharia (IME))

\section{Abstract}

This paper aims to apply the hybrid method AHP-TOPSIS-2N for the selection of an attack helicopter to be acquired by the Brazilian Navy. Six helicopter models, among the most used by the Armed Forces of developed countries, were compared. The selected helicopter would be employed in the fire support required by the Brazilian Marine Corps Amphibious Operations. The helicopters had seven criteria - maximum speed, payload, number of rockets, number of air-to-ground missiles, range, main cannon and amount of ammunition for the guns - evaluated by airship officers of the Brazilian Navy. The application of the method presented two lists of ordering and prioritization of the helicopters as result, providing a richer and more robust sensitivity analysis, which provides security, transparency and simplicity to the decision-making process. After the application of the method, the AH-64E APACHE and 
MI-35M helicopters were chosen as the most suitable to be acquired.

EVALUATION OF KEY TECHNOLOGICAL TOOLS IN TERMS OF SUPPLY CHAIN SUSTAINABILITY IN THE DIGITALIZATION ERA WITH DIFFERENT ANALYTIC HIERARCHY PROCESS METHODS

ABDULLAH YILDIZBASI (Turkey) ${ }^{1}$, Cihat OZTURK (Turkey) ${ }^{1}$, Sachin Kumar MANGLA (United Kingdom)3), Yiğit KAZANCOGLU (Turkey) ${ }^{4}$ (1. Ankara Yıldırım Beyazıt University, 2. University of Plymouth, 3. Yaşar University) Abstract

The complex business processes bring various problems such as lack of transparency, asymmetrical information flow, lack of security, and insufficient traceability are decrease service quality and increase costs. Besides, it brings social inequality along with its environmental effects. This study examines the impact of new concepts and technologies such as loT, blockchain, big data, cloud computing, and robotics on supply chain sustainability. In this study, Analytic Hierarchy Process (AHP) and its variations (Fuzzy AHP, Intuitionistic F-AHP, Pythagorean F-AHP, Spherical F-AHP) are discussed, the evaluation of innovative technologies in terms of each method is made through the concept of sustainability. The results obtained are important in showing both the consistency of AHP methods among themselves and which technologies are at the forefront for sustainability.

\section{USING AHP AND QFD IN THE INVESTIGATION AND REFINEMENT} OF E-BANKING SERVICES

Georgios Paltayian (Greece) ${ }^{1}$, Andreas Georgiou (Greece) ${ }^{1}$, Katerina Gotzamani (Greece) $)^{1}$ (1. University of Macedonia)

\section{Abstract}

The purpose of this paper is to introduce a Quality Function Deployment - Analytic Hierarchy Process decision tool in the direction to support ebanking services. The final product of the model is a House of Quality matrix and AHP was used to determine the intensity of the relationship between e-banking quality attributes and e-banking platform activities. Through this research the established QFD-AHP model supports decision makers in adopting innovating strategies that might increase e-banking usage and reduce customer churn. A case study from a Greek bank was 
used to validate the model.

\section{AHP STUDENTS ROUNDTABLE}

\section{$1: 05 p m$}

\section{Room: Zoom PNL1}

\section{Speakers:}

Dr. Enrique Mu (United States) - Carlow University

Dr. Elena Rokou - Creative Decisions Foundation

Dr. Anna Florek-Paszkowska (Peru) - CENTRUM Católica Graduate Business School, Lima, Perú Pontificia Universidad Católica del Perú, Lima, Perú

This panel of students, selected by their quick grasp of and interest in AHP/ANP, will be facilitated by faculty members who will lead the discussion toward answering the following questions:

1. What are the benefits of learning AHP as part of their coursework instruction?

2. What are the enjoyable aspects of learning AHP?

3. What are the challenges students face to learn AHP?

4. What suggestions students would make toward the goal of improving AHP instruction at the college level?

\section{CLOSING/ AWARDS CEREMONY}

\section{2:05pm}

\section{Room: Zoom AWRD}

Speakers:

Dr. Enrique Mu (United States) - Carlow University

Rozann Saaty (United States) - Creative Decisions Foundation 1:00 to $2: 30 \mathrm{pm}$ 


\section{A}

Adams, William $21,34,43,77$

Alalhesabi, mehran 34,78

Amaloo, Rajan 39,95

Amponsah, Chris 32,69 Amponsah, Tamara Opokua ....... 32, 69 Andriichuk, Oleh 28,56

Anis, Azilah $18,38,94$

Antonio Bojórquez-Tapia, Luis .... 26, 51 Asad, Muhammad 35,80

Assumma, Vanessa 26,50

Astanti, Ririn .. 16

Atreya, Komal 38,91 aydin, serhat 33,73

Azizi, Majid $16,27,54$

\section{B}

Bahurmoz, Asma 16

Bastida-Molina, Paula . 31,65

Bayazit, Ozden $16,36,85$

Begicevic, Nina 20

Bejicevic, Nina 16

Beltrán, Pablo Aragonés . 16

Berzins, Lorena 27,53

Bhattarai, Shashi $16,20,35,82$

Bishwokarma, Rajiv 37,91

Bochkov, Alexander 25,47

Bojórquez-Tapia, Luis Antonio... 30, 34, $37,65,80,88$

Borrego-Areyanes, Arlen 39,96

Bottero, Marta 26,50

Bozóki, Sándor 31,67
C

Castillo, Mario 16

Castro Junior, Marcos Alexandre Pinto de 29, 36, 40, 61, 86, 98 Chansa-ngavej, Chuvej.... 33,75

Chapagain, Nawa Raj 37,90

Chen, $\mathbf{X i}$. $19,32,37,68,87$

Ciardiello, Francesco....... 33, 37, 74, 89 Cooper, Orrin 16, 20, 21, 31, 34, 41, 68, 78

Corona-Sobrino, Carmen 26,49 Corriça, José Victor de Pina.. 29, 36, 40, 61, 86, 98

Costa, Arthur Pinheiro de Araújo29, 36, 40, 61, 86, 98

Costa, Igor Pinheiro de Araújo ... 29, 36, 40, 61, 86, 98

Cvetkoska, Violeta 32,69

D

De Felice, Fabio $16,35,80$ Dhamala, Tanka 32,70 Diarjan, Mohammad Solemani ... 27, 54 Divjak, Blazenka 39,96 Divjak, Blaženka 22,50 Dixon-Ogbechi, Bolajoko Nkemdinim 16 Dong, Qingxing .... 16 Dytczak, Miroslaw. 16

\section{E}

Eakin, Hallie 30,65

Emeksiz, Faruk 33,72

Esposito, Emilio 16 
F

Fávero, Luiz Paulo 40,98

Ferraro, Antonella 35,82

Fiala, Peter 16

Fico, Giuseppe 16

Florek, Anna . .20

Florek-Paszkowska, Anna ... 16, 24, 100

\section{G}

Garuti, Claudio.....16, 19, 28, 35, 57, 81 Genovese, Andrea $33,37,74,89$

Georgiou, Andreas 40,99

Ghimire, Saroj 37,91

Ghimire, Subash 39,97

Ginda, Grzegorz $16,29,60$

Gomes, Carlos Francisco Simões 29, 36, 40, 61, 86, 98

Gómez-Navarro,Tomás 31,65

Gómez-Priego, Paola 26,51

Gómez-Villar, Iván-Darío 39,96

Gonzalez, Hannia. .. 19

Gonzalez-Urango, Hannia .... 26, 30, 48, 49,65

Gotzamani, Katerina 40,99 Grave, lleana.26, 30, 34, 37, 51, 65, 80, 88

Gündoğdu, Fatma Kutlu 38,92

\section{$\mathrm{H}$}

Haas, Rainer 25,46

Hackl, Sonja 25,46

Herawan, Didit. .. 16

Hermogenes, Lucas Ramon dos.. 27, 53

Hernández-Díaz, Victor 34,80

Hurtado, Jenny. 39,94

Hurtado, Katherine 39,94

Hurtado-Pérez, Elías 31,65 lida, Yoichi 30,64 İmamoğlu, Gül 26,51 Ishizaka, Alessio ..16, 18, 23, 26, 40, 50, 70, 98 Islam, Rafikul $16,18,27,53,54$

J

Jablonsky, Josef. 16 Jamlean, Anselmus 36,86 Joshi, Neha. 37,90

\section{K}

Kadaifci, Cigdem..18, 30, 32, 36, 63, 85 Kadenko, Sergii $25,28,47,56$

Kadoic, Nikola. 20

Kaftandzieva, Tamara 32,69

Kahraman, Cengiz.. 16

Karadayi-Usta, Saliha 27,52

Karasan, Ali 38,92

Karpak, Blrsen 16

KAZANCOGLU, Yiğit 40,99

Kazibudzki, Pawel. 31,67

Khanal, Durga 32,70

Kheybari, Siamak 19

Kinoshita, Eizo.................................... 16

Kirytopoulos, Konstantinos ................ 16

Koul, Saroj... 16

Krejci, James $32,36,72,86$

Kuzko, Oleksandr 30,63 Kuzmina, Nataliya 25,47

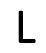

Latora, Antonio .......................... 28, 58

Leon, Yuli ................................... 38, 91

Leonov, Mykola......................... 30, 63

Leyton, Juliana .......................... 38, 92

Li, Xin ........................................ 37, 87

Lima, Carolina ............................ 39, 94 
Lipovetsky, Stan $.16,28,34,56,76$

Luo, Shucheng

33,74

\section{M}

Macuada, Claudio 37,87

Mancini, Paola 35,82

MANGLA, Sachin Kumar 40, 99

Marcarelli, Gabriella $17,35,82$

Marins, Fernando 29,60

Marsh, Anastasia 31,66

Meixner, Oliver $17,25,46$

Melon, Monica Garcia....19, 25, 26, 48, 49

Melón, Mónica García 16

Merino, Tatiana $34,37,80,88$

Mikhailov, Ludmil. 17

Miquelajauregui, Yosune 34,80 MITIHIRO DO NASCIMENTO MAÊDA, SÉRGIO $29,36,40,61,85,98$ Mls, Karel..... ... 17

Moreira, Miguel. 27,53

Moreno-Jiménez, José María.... 18, 27, $33,55,76$

Mu, Enrique ..13, 17, 21, 22, 24, 28, 31, $38,42,46,60,66,91,100$

N

Nelson, Donald R 30,65

Netto, Antonio 33,75

Ngenget, Stevanus

32,72

NIKIEMA, Frédéric 37,90

Oddershede, Astrid 37,87 Ohoitimur, Johanis $32,36,72,86$ Oliveira, José 35,83 Oliveira, Lidiane Cristina 29,62 Ortiz Barrios, Miguel Angel ... 19 Ortíz-Barrios, Miguel. Osorio, Juan 39,96 $38,39,92,94$
Ostrega, Anna 17

Otero-Hermida, Paula 26, 48

Ozdemir, Mujgan Sagir 17

Ozdemir, Mujgan Sagir 17

OZTURK, Cihat. 40, 99

\section{P}

Pachecco, Bruna Cristine Scarduelli. 29, 62

Padoano, Elio 17

Palominos, Pedro 37,87

Paltayian, Georgios 40,99

Paramaporn, Natchanok 33,75

Patrone, Carlotta 28,58

Paudyal, Binay. 37,91

Pecchia, Leandro. 17

Petrillo, Antonella ....13, 17, 35, 39, 80, 81, 96

Piratelli, Claudio Luis 29,62

Poudel, Sovit 35,82 Poveda-Bautista, Rocío $17,26,49$ Pyakurel, Urmila 32,70<smiles>[O]</smiles>

Quezada, Luis 37,87

\section{R}

Raco, Jozef..... $32,36,72,86$

Rai, Bibek ..... 37,91 raton, yulius $32,36,72,86$

Redjep, Nina Begicevic. 39,96 Regmi, Ashish 37,91 Revetria, Roberto 28,58 Ribo-Perez, David........................ 31, 65 Ridley, Alexandra ........................ 25, 47 rivest, robin................................. 34, 77 Rojas, Jorge ................................ 38, 94 Rokou, Elena 17, 21, 24, 34, 44, 77, 100 Ruiz, David 29,60 
$S$

Saaty, Daniel 21,45

Saaty, Rozann $.12,22,39,95,100$

Saaty, Thomas L. 15

Sagir, Mujgan $19,37,87$

Sağır, Müjgan .. 87

Salomon, Valerio $.17,19,33,74,75$

Sandoval, Mario $19,38,91$

Santos, Marcos dos...27, 29, 36, 40, 53, $61,86,98$

Sato, Yuji. 17

Savadogo, Zoïnabo 37,90

SAWADOGO, Somdouda. 37,90

Serrano-Candela, Fidel. 34,80

Sgalambro, Antonino 33,74

Shang, Jennifer 15,17 Sharma, Deven. 27,54 shemirani, seyed majid mofidi.... 34, 78 Shih, Hsu-Shih . .17

Simeoni, Patrizia . .17

Smith, Carlo 36,85

SOME, Blaise 37,90

Soputan, Jeanette 32,72

Spencer, Isabel... ... 17

Subedi, Subrat. 37,90

Szádoczki, Zsombor 31,67 Szyba, Marta 29,60

T

Tanod, Rafael 36,86

Taroreh, Frankie 32,72

Tasnim, Kazi
Teixeira, Luiz Frederico Horácio de

Souza de Barros $29,36,61,86$

Tekile Hailemariam Abebe ......... 31, 67

Tocalinho, Ana Beatriz 33,75

Topcu, Ilker $18,26,30,51,63$

Topçu, Ilker 17

Tsyganok, Vitaliy $25,28,47,56$

\section{V}

Vargas, Luis...10, 15, 17, 18, 21, 25, 31, $37,42,46,66,89$

Veziroğlu, Püren............. 30, 33, 63, 72

Villa, Daniel 35,81

\section{W}

Wang , Xiaojun...... 17

Wedley, William $24,31,68,93$

Welerubun, Ignasius 36,86

\section{Y}

YILDIZBASI, ABDULLAH 40,99

Yoon, Min-Suk 17

YOON, MinSuk 27,55 yorukoglu, mehmet 33, 73

\section{Z}

Zhigirev, Nikolay 25,47

Zhu, Keyu 17

Zugec, Bojan 39,96 


\section{CONFERENCE PARTICIPANTS - CONTACT INFORMATION}

\section{A}

Abamo, Antonio Pajo, antonio.abamo@gmail.com

Abastante, Francesca, francesca.abastante@ polito.it

Abbas, Mohammed, abbmy007@mymail.unisa.edu.au

abbas, mohammed, mohammed202215@gmail.com

Abdelkader, KHELLADI - USTHB, aekhelladi@gmail.com

Abdi, Reza, r.abdi@bradford.ac.uk

Accorsi, Stephanie, saaccorsi@live.carlow.edu

Adams, William, Decision Lens, wjladams@gmail.com

Adams, William, Decision Lens, wjadams@decisionlens.com

Adamus, Wiktor, wiktor.adamus@uj.edu.pl

Agaeva, Kamila, National Research University Higher School of Economics

(HSE University), kshagaeva@edu.hse.ru

Agapie, Adriana, adriana.agapie@yahoo.com

Aguarón, Juan, aguaron@unizar.es

Ahmed, Selim, selim.ahmed@business.wub.edu.bd

Akhgari, Ali, ali.akhgari@gmail.com

Alalhesabi, mehran,"Associate professor of Urbanism, School of Architecture and Urban Development, Iran University of Science and Technology.",

mehranalalhesabi@iust.ac.ir

Ali, Abid, abid.msse176@iiu.edu.pk

Amaloo, Rajan, AM, rajan.amaloo@gmail.com

Amponsah, Chris, Yorkville University, chris_tabi@ hotmail.com

Andriichuk, Oleh,"National Technical University of Ukraine "Igor Sikorsky

Kyiv Polytechnic Institute", andriichuk@ipri.kiev.ua

Anis, Azilah, azilahanis@salam.uitm.edu.my

Anis, Azilah, zilahanis@salam.uitm.edu.my

Anis, Azilah, azilahanis@uitm.edu.my

Aragonés-Beltrán, Pablo, aragones@dpi.upv.es

Arredondo, Maria Teresa, mta@lst.tfo.upm.es

Asad, Muhammad,"Department of Engineering - University of Naples

"Parthenope", Italy", muhammad.asad@ uniparthenope.it

Assumma, Vanessa, Polytechnic, vanessa.assumma@polito.it

Astanti, Ririn Diar, ririn.astanti@uajy.ac.id

Atreya, Komal, Nepal Electricity Authority, komalatreya@yahoo.com

aydin, serhat, MSÜ Hava Harp Okulu, saydin3@hho.edu.tr

Azizi, Majid, University of Tehran, mazizi@ut.ac.ir 
Báez, Patricia, p.baezmiranda@gmail.com

Bahurmoz, Asma, asma@bahurmoz.com

BAKAR, NUR AZALIAH, azzaliya@gmail.com

Bastida-Molina, Paula, Institute for Energy Engineering. Universitat Politècnica de València, paubasmo@etsid.upv.es

Bayazit, Ozden, Central Washington University, bayazito@cwu.edu

bayazit, ozden, ozden.bayazit@cwu.edu

Begicevic Redjep, Nina, University of Zagreb, nina.begicevic@foi.hr

Belderrain, Mischel Carmen Neyra, carmen.beld@gmail.com

Belderrain, Carmen, carmen@ita.br

Bernal, Astrid Johanna, aj.berna1218@uniandes.edu.co

Berzins, Lorena, Fundação Getúlio Vargas (FGV), lorena.berzins@fgv.br

Bhattarai, Shashi, Knowledge Holding International,

shashibhattarai@yahoo.com

Bishwokarma, Rajiv, NEA Engineering Company,

rajiv.bishwokarma@neaec.com.np

Bochkov, Alexander, JSC NIIAS, a.bochkov@gmail.com

Bojórquez-Tapia, Luis Antonio,"Laboratorio Nacional de Ciencias de la

Sostenibilidad, Instituto de Ecología, UNAM", luis@multicriteria.org

Bonora, Laura, laura.bonora@fecyt.es

Borrego-Areyanes, Arlen,"Department of Business Administration, Universidad de la Costa CUC, Barranquilla", aborrego3@cuc.edu.co

Bottero, Marta, Polytechnic University of Turin, marta.bottero@polito.it

Bozóki, Sándor, Corvinus University of Budapest, bozoki.sandor@sztaki.hu

Brady, Matt, Volley Solutions, matt@volleysolutions.com

BRAUNS, BIANKA, PUC RJ, bbrauns@yahoo.com

C

Cahill, Miranda, mjc184@pitt.edu

CAN, Gülin, gfcan@baskent.edu.tr

Caramuta, Caterina, caterina.caramuta@phd.units.it

Castro Junior, Marcos Alexandre Pinto de, Pontifícia Universidade Católica

(PUC), im.alexandre07@gmail.com

CELIKDEMIR, SAFAK, s.celikdemir@yahoo.com

Chansa-ngavej, Chuvej, "Regional Center for Manufacturing Systems

Engineering, Chulalongkorn University", chuvej@gmail.com

Chapagain, Nawa Raj, NEA Engineering Company, nrc@neaec.com.np

Chen, ChiauChiing, fermat123456789@gmail.com

Chen, Xi, Xidian University, xchen@xidian.edu.cn

Ciardiello, Francesco, Sheffield Management school, f.ciardiello@shef.ac.uk 
Ciardiello, Francesco, Sheffield University Management School, f.ciardiello@sheffield.ac.uk

Cinelli, Dr. Marco, "Laboratory of Intelligent Decision Support Systems Poznań University of Technology, Poznań, Poland", marco.cinelli@put.poznan.pl Cooper, Orrin, University of Memphis, olcooper@memphis.edu Corona-Sobrino, Carmen, Ingenio (CSIC-UPV), carcosob@ingenio.upv.es Corriça, José Victor de Pina, Marinha do Brasil, jvctor97@gmail.com Costa, Igor Pinheiro de Araújo, Universidade Federal Fluminense (UFF), costa_igor@id.uff.br

Costa, Arthur Pinheiro de Araújo, Marinha do Brasil, thurcos91@gmail.com Cvetkoska, Violeta, violeta_cvetkoska@hotmail.com

Cvetkoska, Violeta, Associate Professor, violeta.cvetkoska@eccf.ukim.edu.mk

Dávila, Pablo, UCE, pgdavila@uce.edu.ec

De Felice, Fabio,"Cassino and Southern Lazio, Italy", defelice@unicas.it Degtiarev, Konstantin, National Research University Higher School of Economics (HSE University), kdegtiarev@hse.ru

Deniz, Gizem, denizgi@itu.edu.tr devarakonda, phani, Kris analytics solutions, dvps95@gmail.com Dhamala, Tanka, Tr, amb.dhamala@daadindia.org Divjak, Blazenka, "University of Zagreb, Faculty of organization and informatics", blazenka.divjak@foi.hr

Divjak, Blaženka, "University of Zagreb, Faculty of organization and informatics", bdivjak@foi.hr Dixon-Ogbechi, Bolajoko, bdogbechi@gmail.com

Dutta, Ashish, meashishdutta@gmail.com

Dytczak, Miroslaw, mdytczak@gmail.com

$\mathrm{E}$

Eakin, Hallie, "Arizona State University, School of Sustainability", hallie.eakin@asu.edu Emeksiz, Faruk, cukurova university, femeksiz@cu.edu.tr Estrada-Barón, Alejandra, "Laboratorio Nacional de Ciencias de la Sostenibilidad, Instituto de Ecología, UNAM", ale.esba@gmail.com Euchi, Jalel, Sfax University, jalel.euchi@fsegs.rnu.tn

$\mathrm{F}$

Fan, Ching-Lung,"Department of Civil Engineering, the Republic of China Military Academy", p93228001@ntu.edu.tw 
Fávero, Luiz Paulo, Universidade de São Paulo (USP), lpfavero@usp.br Feili, Ardalan,"Operations Research Department, Faculty of Economic and Administrative Sciences, Ferdowsi University, Mashhad, Iran", ardalan_feili@yahoo.com

Ferraro, Antonella, University of Sannio, antonellaferraro88@live.it Feyzi, Ammar, ammarfeyzi@live.com

Florek-Paszkowska, Anna,"CENTRUM Católica Graduate Business School, Lima, Perú Pontificia Universidad Católica del Perú, Lima, Perú", aflorekpaszkowska@pucp.edu.pe Freyre, Fiorella, fiorella.freyre@gmail.com

Gan, Shu-San, Petra Christian University, gshusan@ @etra.ac.id Garuti, Claudio, Fulcrum Engeneering, claudiogaruti@fulcrum.cl Genovese, Andrea, Sheffield Management school, a.genovese@shef.ac.uk Genovese, Andrea, Sheffield University Management School, a.genovese@sheffield.ac.uk Georgiou, Andreas, Univsity of Macedonia, acg@uom.edu.gr Ghimire, Subash, Kathmandu University, subash_ghimire@ku.edu.np Ghimire, Saroj, NEA Engineering Company Limited, saroj.ghimire@neaec.com.np

Ghimire, Sushma, ghimiresushma99@gmail.com

Ginda, Grzegorz, gginda@agh.edu.pl

Ginda, Grzegorz, AGH UST, gginda@zarz.agh.edu.pl

Gligora Marković, Maja, mgligoram@gmail.com

Godoy Martínez, José Luis, jluisgodoym@gmail.com

Gomes, Carlos Francisco Simões, Universidade Federal Fluminense (UFF), cfsg1@bol.com.br

Gómez-Navarro, Tomás, Institute for Energy Engineering. Universitat

Politècnica de València, tgomez@dpi.upv.es

Gomez-Priego, Paola, Laboratorio Nacional de Ciencias de la Sostenibilidad, pgomez@iecologia.unam.mx

Gómez-Priego, Paola, Laboratorio Nacional de Ciencias de la Sostenibilidad, gomez@iecologia.unam.mx

Gómez-Villar, Iván-Darío, "Department of Business Administration, Universidad de la Costa CUC, Barranquilla", igomez1 @ cuc.edu.co Gonzalez-Urango, Hannia, "Ingenio (CSIC-UPV), Universitat Politècnica de València", gonzalezurango@gmail.com

Gonzalez-Urango, Hannia, Ingenio (CSIC-UPV); Universitat Politècnica de València, hangonur@upv.es

Gotzamani, Katerina, University of Macedonia, kgotza@uom.edu.gr Grave,Ileana, "Laboratorio Nacional de Ciencias de la Sostenibilidad, Instituto de Ecología, UNAM", igrave@iecologia.unam.mx 
Grave, Ileana, Laboratorio Nacional de Ciencias de laSostenibilidad, iigrave@iecologia.unam.mx

Guiora, Amos, S.J. Quinney College of Law University of Utah, amos.guiora@law.utah.edu

Guo, Ning,nguo@xidian.edu.cn

Gupta, Shiva Prakash, Tribhuvan University, shivaprasadgupta99@gmail.com Gupta, Himanshu,"Department of Management Studies, Indian Institute of Technology", himanshuguptadoms@gmail.com

Haas, Rainer, University of Natural Resources and Life Sciences Vienna, rainer.haas@boku.ac.at

Hackl, Sonja, University of Natural Resources and Life Sciences Vienna, sonja.hackl@hotmail.com

Halim, Siana, Petra Christian University, halim@petra.ac.id

Hammad, Dabo,dbhammad_g01661@utp.edu.my

Hannum, Rachel, reh101@ @itt.edu

Hermogenes, Lucas Ramon dos, Instituto Militar de Engenharia (IME), lucas.hermogenes@outlook.com

Hernández-Díaz, Victor, "Laboratorio Nacional de Ciencias de la Sostenibilidad, Instituto de Ecología, UNAM", victor.hernandez@iecologia.unam.mx

Hurtado, Jenny, Universidad del Valle, jenny.hurtado@correounivalle.edu.co Hurtado, Katherine, Universidad del Valle,

katherine.hurtado@correounivalle.edu.co

Hurtado-Pérez, Elías, Institute for Energy Engineering. Universitat Politècnica de València, ejhurtado@die.upv.es

İmamoğlu, Gül, Karadeniz Technical University, gulimamoglu@ktu.edu.tr Ishizaka, Alessio, NEOMA Business School, alessio.ishizaka@neoma-bs.fr Islam, Rafikul, "Department of Business Administration, International Islamic University Malaysia", rislam@iium.edu.my

$\mathrm{J}$

Jablonsky, Josef, jablon@vse.cz

Jamlean, Anselmus, Sekolah Tinggi Filsafat Seminari Pineleng,

anseljamleanmsc@yahoo.co.id

Jimenez, Genett, gjimenez@itsa.edu.co

Jones, Nicolette, nlj13@pitt.edu

Joshi, Neha, NEAEC, nehajoshi3113@gmail.com 
Kadaifci, Cigdem, cigdem.kadaifci@gmail.com

Kadaifci, Cigdem, kadaifci@itu.edu.tr

Kadenko, Sergii, Institute for Information Recording of the National Academy of Scienes of Ukraine, seriga2009@gmail.com

Kadoic, Nikola, "University of Zagreb, Faculty of organization and informatics", nkadoic@foi.hr

Kaftandzieva, Tamara, PhD Student, tamara.kaftandzieva@gmail.com

Kahraman, Cengiz, kahramanc@itu.edu.tr

kaini, surendra, surendrakaini@gmail.com

Karadayi-Usta, Saliha, Fenerbahce University, salihakaradayiusta@gmail.com

Karasan, Ali, Yildiz Technical University, akarasan@yildiz.edu.tr

Karpak, Birsen, Youngstown State University, bkarpak@ysu.edu

KAZANCOGLU, Yiğit, Yaşar University, yigit.kazancoglu@yasar.edu.tr

Kazemi, Mostafa, "Operations Research Department, Faculty of Economic and Administrative Sciences, Ferdowsi University, Mashhad, Iran",

kazemi@um.ac.ir

Kazemi, Mostafa,"Operations Research Department, Faculty of Economic and Administrative Sciences, Ferdowsi University, Mashhad, Iran",

feili@apadana.ac.ir

Kazibudzki, Pawel, Opole University of Technology, emailpoczta@gmail.com

KC, Prajwol, prajwol.kc9809538016@gmail.com

Ken-Opurum, Bobuchi, bkenopur@andrew.cmu.edu

KHAKDAMAN, MASOUD, Delft University of Technology,

m.khakdaman@tudelft.nl

Khanal, Durga, Tribhuvan University, durgapsdkhanal@gmail.com

Kheybari, Siamak, NEOMA Business School, siamak.kheybari@neoma-bs.fr

Koul, Saroj, skoul@jgu.edu.in

Kraus, Nora,nak148@pitt.edu

Krejci, James, Lewis University, krejcija@lewisu.edu

KRISHNAN, Deven Sharma, "Graduate School of Management, International

Islamic University Malaysia", deven.krishnan@yahoo.com

Kumar, Nirmal, urwithnirmal@gmail.com

Kutlu Gündoğdu, Fatma,National Defence University, kgundogdu@hho.edu.tr

Kuzko, Oleksandr, Selfemployed, uackuzko@ukr.net

Kuzmina, Nataliya, Moscow State Technical University of Civil Aviation,

n.kuzmina@mstuca.aero

kwak, yumi, o_o_van@naver.com

$\mathrm{L}$

Latifi, Ali, TU Delft, s.m.a.latifirostami@tudelft.nl

Latora, Antonio, alatora@dii.unict.it

ISAHP 2020 
Latora, Antonio G., Regione Lazio, alatora@ regione.lazio.it

Le Pira, Michela, michela.lepira@gmail.com

Leon, Yuli, University Rosario, yuli.leon@urosario.edu.co

Leonov, Mykola, State Institution National Antarctic Scientific Center of

Ukraine, g60s1981@gmail.com

Leyton, Juliana, universidad, juliana.leyton@ correounivalle.edu.co

Li, Xin, Xidian University, xinxinli@stu.xidian.edu.cn

Ligardo, Ivan, ivliher@upv.es

Lima, Carolina, Universidad del Valle, martha.lima@correounivalle.edu.co

Lipovetsky, Stan, independent consultant, stan.lipovetsky@gmail.com

Liptock, Brandi, bliptock@live.carlow.edu

Lozada, Pedro, a20207610@pucp.edu.pe

Luo, Shucheng, Sheffield Management school, sluo5@sheffield.ac.uk

\section{M}

Macuada, Claudio, University of Santiago of Chile, claudio.macuada@usach.cl MADRID, LIZBET, lmadrid382@gmail.com

Mahdi Rezaie, Fariba, University of Guilan, fariba.m.rezaie@gmail.com

mahmoudzadeh vaziri, Alireza, e.alireza.vaziri@gmail.com

Mamani, Mercedes, mercedes.mamani@pucp.edu.pe

Mancini, Paola, University of Sannio, paola.mancini@unisannio.it

MANGLA, Sachin Kumar, University of Plymouth, sachinmangl@gmail.com

Marcarelli, Gabriella, gabriella.marcarelli@gmail.com

Marcarelli, Gabriella, University of Sannio, gabriella.marcarelli@unisannio.it

Marcello Oentoro, Jerry, Petra Christian University, jmoentoro17@gmail.com

Marinho, Lucia, Universidade Federal do Estado do RJ,

luciamarinho16@hotmail.com

Marins, Fernando, Sao Paulo State University, fernando.marins@unesp.br

Marsh, Anastasia, Carlow University, amarsh@live.carlow.edu

Meixner, Oliver, Universität für Bodenkultur Wien, oliver.meixner@boku.ac.at

Melon, Monica Garcia, Ingenio (CSIC-UPV), mgarciam@dpi.upv.es

Merino, Tatiana, "Posgrado en Ciencias de la Sostenibilidad, UNAM",

tatianam@iecologia.unam.mx

Messina, Vanessa, Estacio de Sa University, vanessamessina@gmail.com

Minutolo, Marcel C, Robert Morris Universtiy, minutolo@rmu.edu

Miquelajauregui, Yosune, "Laboratorio Nacional de Ciencias de la

Sostenibilidad, Instituto de Ecología, UNAM", yosune @iecologia.unam.mx

MITIHIRO DO NASCIMENTO MAÊDA, SÉRGIO, Universidade Federal

Fluminense (UFF), sergiomnmaeda@gmail.com

mofidi shemirani, seyed majid, "Assistant Professor in urban design, School of Architecture and Urban Development, Iran University of Science and

Technology.", mofidi@iust.ac.ir 
Moradi, Mahmood, University of Guilan, mahmoudmoradi@gmail.com

Moreira, Miguel, Instituto Militar de Engenharia (IME),

miguellellis@hotmail.com

Moreno-Jiménez, José María, moreno@unizar.es

$\mathrm{Mu}$, Enrique, Carlow University, emu@ carlow.edu

Muhibbullah, Md, "Faculty of Economics and Management Sciences,

International Islamic University Malaysia", muhibedu@gmail.com

Nelson, Donald R, "University of Georgia, UGA, Department of Anthropology", dnelson@uga.edu

Netto, Antonio, Sao Pau, antonio.lombardi@unesp.br

Ngenget, Stevanus, Universitas Katolik De La Salle Manado,

sngenget@unikadelasalle.ac.id

NIKIEMA, Frédéric, Université Joseph KI-ZERBO,

fredericnikiema0@gmail.com

$\mathrm{O}$

Oddershede, Astrid, University of Santiago of Chile,

astrid.oddershede@usach.cl

Ohoitimur, Johanis, Sekolah Tinggi Filsafat Seminari Pineleng,

ohoitimur@yahoo.com

Oliveira, Lidiane Cristina, Universidade de Araraquara - UNIARA,

lidi_sts@hotmail.com

Oliveira, José,"Universidade Estadual Paulista ""Júlio de Mesquita Filho"" -

UNESP", carlos.souza@ifsp.edu.br

Oliveira, Lidiane Cristina, University of Araraquara - UNIARA,

lidi_sts@hotmail.com.br

onsel, sule, sonsel@dogus.edu.tr

Opokua Amponsah, Tamara, Ross University School of Medicine,

tamaraadjoa@gmail.com

Oreški, Dijana, dijoresk@foi.hr

Orr, Emily, esorr@live.carlow.edu

Ortiz, Miguel, mangelo2008@gmail.com

Ortíz-Barrios, Miguel, "Department of Productivity and Innovation, Universidad de la Costa CUC, Barranquilla", mortiz1 @ cuc.edu.co

Osorio, Juan, Universidad del Valle, juan.osorio@correounivalle.edu.co

Otazu, Jorge,jotazuc@gmail.com

Otero-Hermida, Paula, Ingenio (CSIC-UPV), pauother@upvnet.upv.es

OZTURK, Cihat, Ankara Yıldırım Beyazıt University, cihatozturk86@gmail.com 
Padoano, Elio, padoano@units.it

Palominos, Pedro, University of Santiago of Chile, pedro.palominos@usach.cl Paltayian, Georgios, University of Macedonia, gpaltag@uom.edu.gr Panahi, Masoud, masoud_panahi_68@yahoo.com Paramaporn, Natchanok, "Regional Center for Manufacturing Systems Engineering, Chulalongkorn University", natnatchanok4@gmail.com Patrone, Carlotta, E.O. Ospedali Galliera, patronecarlotta@gmail.com Paudyal, Binay, NEA Engineering Company Limited, vinaypaudyal@gmail.com Pawlowski, Kaitlyn, kpawlowski@live.carlow.edu Peniwati, Kirti, kirti@indo.net.id Perez Gladish, Blanca, blancaperezgladish@gmail.com Petrillo, Antonella, a.petrillo@unicas.it Petrillo, Antonella, Department of Engineering - University of Naples "Parthenope", antonella.petrillo@uniparthenope.it Pinho, Alexandre, pinho@unifei.edu.br Piratelli, Claudio Luis, University of Araraquara - UNIARA, clpiratelli@uniara.edu.br

Poudel, Sovit, Truenary Solutions, sovit.poudel@gmail.com

Poveda-Bautista, Rocío, Ingenio (CSIC-UPV); Universitat Politècnica de València, ropobau@upvnet.upv.es pratama, bary, airputih0606@gmail.com Pyakurel, Urmila, Tribhuvan University, urmilapyakurel@gmail.com

Q

Quezada, Luis, University of Santiago of Chile, luis.quezada@ usach.cl h $\mathrm{R}$

Raco, Jozef, Universitas Katolik De La Salle Manado, jraco@unikadelasalle.ac.id

Rahman, Mahbubar,mmr.iium@gmail.com

Rai, Bibek, NEA Engineering Company Limited, ktorai070@gmail.com

raton, yulius, Universitas Katolik De La Salle Manado, yraton@unikadelasalle.ac.id

Regmi, Ashish, NEA Engineering Company Limited, aashishregmi99@gmail.com

Revetria, Roberto, Università degli Studi di Genova, roberto.revetria@unige.it Ribó Pérez, David, daripre@upv.edu.es 
Ribo-Perez, David, Institute for Energy Engineering. Universitat Politècnica de València, david.ribo@iie.upv.es

Ridley, Alexandra, Moscow Aviation Institute (National Research University), alexandra.ridley@yandex.ru

Ridley, Alexandra, sunridl@gmail.com

rivest, robin, independant consultant, robin.rivest@ videotron.ca

Rojas, Jorge, universidad, jorge.arlevis.rojas@correounivalle.edu.co

Rokou, Elena, CDF, erokou@gmail.com

Rokou, Elena, Creative Decisions Foundation, erokou@icloud.com

Romero, Brandon Antonio Aleman, baleman1@cuc.edu.co

Romero, Jorge, jorgei.romerog@utadeo.edu.co

Romero, Pamela, pamelagsromero@gmail.com

Rucano, Ruben, ruben.rucano.m@upch.pe

Ruiz, David, Sao Paulo State University, david.ruiz@unesp.br

$\mathrm{S}$

Saaty, Rozann, Creative Decisions Foundation, rozann@creativedecisions.net Saaty, Daniel, Decision Lens, dsaaty@decisionlens.com

Sadasivuni, Ravi, Kris analytics solutions, rsadasivuni3@gmail.com

Sagir, Mujgan, Eskisehir Osmangazi University, msagir@ogu.edu.tr

Sağır, Müjgan, Eskisehir Osmangazi University, mujgan.sagir@gmail.com

Salamirad, Amirhossein, Sharif University of Technology,

asalamirad@yahoo.com

Salomon, Valerio, Sao Paulo State University, valerio.salomon@unesp.br

Sandoval, Mario, marsam1061@gmail.com

Santos, Marcos dos, Instituto Militar de Engenharia (IME),

marcosdossantos_doutorado_uff@yahoo.com.br

Saracoglu, Burak Omer, burakomersaracoglu@ hotmail.com

Savadogo, Zoïnabo, university of Joseph Ki-Zerbo, serezenab@yahoo.fr

SAWADOGO, Somdouda,Institut Des Sciences (IDS),somdouda@gmail.com

Scarduelli Pachecco, Bruna Cristine, University of Araraquara - UNIARA, bcspacheco@uniara.edu.br

Serrano-Candela, Fidel,"Laboratorio Nacional de Ciencias de la Sostenibilidad, Instituto de Ecología, UNAM", serranoycandela@gmail.com

Sgalambro, Antonino, Sheffield University Management School,

a.sgalambro@sheffield.ac.uk

Silwal, Abinash, afactor.abinash@gmail.com

Simões, Amanda, amanda.acsimoes@gmail.com

Slibar, Barbara, bslibar@foi.unizg.hr

Šmidovnik, Tjaša, tjasa.smidovnik@bf.uni-lj.si

Smith, Carlo, Central Washington University, carlo.smith@cwu.edu

Smith, Carlo, csmith@cwu.edu 
Solemani Diarjan, Mohammad, universty of Tehran, solemani.diarjan@ut.ac.ir Soltanali, Hamzeh, Ferdowsi university of Mashhad, ha.soltanali@mail.um.ac.ir SOME, Blaise, Université Joseph KI-ZERBO, blaisesome@gmail.com

Soputan, Jeanette, Universitas Sam Ratulangi Manado, jeanette@unsrat.ac.id Subedi, Subrat, NEA Engineering Company Limited, subrat.sbd@gmail.com Subedi, Anil, subedianil838250@gmail.com

Subedi, Pratigya, subedi.pratss@gmail.com

Szádoczki, Zsombor, Corvinus University of Budapest, zsombcu@gmail.com Szarleta, Ellen, ele6@mac.com

Szyba, Marta,"AGH UST, Cracow, Poland", mszyba@zarz.agh.edu.pl

Tamang, Sunil, tamangsunil112233@gmail.com

Tanod, Rafael, Universitas Katolik De La Salle Manado, revimario@yahoo.com Taroreh, Frankie, Universitas Katolik De La Salle Manado, ftaroreh@unikadelasalle.ac.id

Tasnim, Kazi, Student, kazitasnim@college.harvard.edu

Teixeira, Luiz Frederico Horácio de Souza de Barros, Centro de Análises de Sistemas Navais (CASNAV), frederico.horacio@gmail.com

Tekile, Hailemariam Abebe, University of Trento, hailebb@gmail.com

Tenzin, Jigme, jigme.surveyor@gmail.com

Tocalinho, Ana Beatriz, Sao Paulo State University (UNESP), ana.tocalino@unesp.br

Tocalino, Ana Beatriz, Sao Paulo State University, anabsan@uol.com.br

Topcu, Ilker, Ista, ilker.topcu@itu.edu.tr

Topcu, Ilker, istanbul technical university, topcuil@itu.edu.tr

Topcu, İlker, istanbul technical university, yitopcu@gmail.com

Tramarico, Claudemir, BASF, claudemir.leif@terra.com.br

Tsai, Hsin-Yi, leo021092@hotmail.com

Tsyganok, Vitaliy, Institute for Information Recording of the National Academy of Scienes of Ukraine, vitaliy.tsyganok@gmail.com

Tsyganok, Vitaliy, "National Technical University of Ukraine "Igor Sikorsky Kyiv Polytechnic Institute", Institute for Information Recording of National Academy of Sciences of Ukraine", tsyganok@ipri.kiev.ua

$\mathrm{U}$

Upadhyay, Binita, binitaup12@gmail.com

V

Vargas, Manuel, Universidad San Sebastian, manuel.vargas@uss.cl

Vargas, Luis, University of Pittsburgh, lgvargas@ pitt.edu 
Veziroğlu, Püren, cukurova university, purenveziroglu@gmail.com

Villa, Daniel, Fulcrum, danielvilla@fulcrum.cl

Virreira, Julio, jvirreiraflores@gmail.comVillanueva, Ricardo Antonio, Thesis

Presenter on AHP, ricardo_villanueva@dlsu.edu.ph

Vinton, Kenneth, Pain Relief \& Wellness Strategies Center,

unknown@email.com

W

Wagle, Sachin, sachinwagle100@gmail.com

Waslousky, Isabella, Carlow University, bella.waslousky@gmail.com

Wedley, William, Simon Fraser University, w_wedley@sfu.ca

Wedley, William,wedley@sfu.ca

Wei, Lirong, lw90@pitt.edu

Welerubun, Ignasius, Sekolah Tinggi Filsafat Seminari Pineleng, igomsc@yahoo.com

\section{Y}

Yankova, Dima, dnyankov@ doctor.upv.es

YILDIZBASI, ABDULLAH, Ankara Yıldırım Beyazıt Üniversitesi, ayildizbasi@ybu.edu.tr

YOON, MinSuk, "Electronic Commerce, Chonnam National University", msyoon@jnu.ac.kr

Yoon, Min-Suk, msyoon@chonnam.ac.kr

yorukoglu, mehmet, National Defence University Air Force Academy,

myorukoglu1@hho.edu.tr

Z

Zhang, Wenkai, bitzwk@gmail.com

Zhigirev, Nikolay, KALABI IT, nnzhigirev@mail.ru

zolfigol, sajjad, iran university of scicence and technology,

s.zolfigol@yahoo.com

Zugec, Bojan, "Universty of Zagreb, Faculty of organization and informatics", bojan.zugec@unizg.foi.hr

Žugec, Bojan, bojan.zugec@foi.hr 
